SUPPLYING THE MATERIEL BATTLE:

COMBINED LOGISTICS IN THE CANADIAN CORPS, 1915-1918

by

Michael Patrick Ryan, B.A.

A thesis submitted to the Faculty of Graduate Studies and Research in partial fulfilment of the requirements for the degree of Master of Arts

\author{
Department of History \\ Carleton University \\ Ottawa, Ontario \\ 15 August 2005
}

(C) Copyright

2005, Michael Patrick Ryan 


$\begin{array}{ll}\begin{array}{l}\text { Library and } \\ \text { Archives Canada }\end{array} & \begin{array}{l}\text { Bibliothèque et } \\ \text { Archives Canada }\end{array} \\ \begin{array}{l}\text { Published Heritage } \\ \text { Branch }\end{array} & \begin{array}{l}\text { Direction du } \\ \text { Patrimoine de l'édition }\end{array} \\ \begin{array}{l}\text { 395 Wellington Street } \\ \text { Ottawa ON K1A ON4 }\end{array} & \begin{array}{l}\text { 395, rue Wellington } \\ \text { Ottawa ON K1A ON4 } \\ \text { Canada }\end{array}\end{array}$

Your file Votre référence ISBN: 978-0-494-18244-4 Our file Notre référence ISBN: 978-0-494-18244-4

NOTICE:

The author has granted a nonexclusive license allowing Library and Archives Canada to reproduce, publish, archive, preserve, conserve, communicate to the public by telecommunication or on the Internet, loan, distribute and sell theses worldwide, for commercial or noncommercial purposes, in microform, paper, electronic and/or any other formats.

The author retains copyright ownership and moral rights in this thesis. Neither the thesis nor substantial extracts from it may be printed or otherwise reproduced without the author's permission.
AVIS:

L'auteur a accordé une licence non exclusive permettant à la Bibliothèque et Archives Canada de reproduire, publier, archiver, sauvegarder, conserver, transmettre au public par télécommunication ou par l'Internet, prêter, distribuer et vendre des thèses partout dans le monde, à des fins commerciales ou autres, sur support microforme, papier, électronique et/ou autres formats.

L'auteur conserve la propriété du droit d'auteur et des droits moraux qui protège cette thèse. $\mathrm{Ni}$ la thèse ni des extraits substantiels de celle-ci ne doivent être imprimés ou autrement reproduits sans son autorisation.
In compliance with the Canadian

Privacy Act some supporting forms may have been removed from this thesis.

While these forms may be included in the document page count, their removal does not represent any loss of content from the thesis.
Conformément à la loi canadienne sur la protection de la vie privée, quelques formulaires secondaires ont été enlevés de cette thèse.

Bien que ces formulaires aient inclus dans la pagination, il n'y aura aucun contenu manquant.

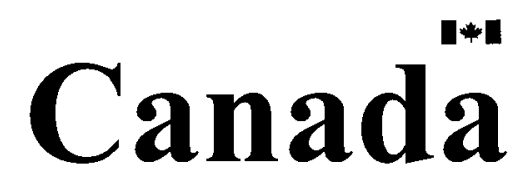


The Department of History recommends to the Faculty of Graduate Studies and Research acceptance of the thesis

\title{
SUPPLYING THE MATERIEL BATTLE: \\ COMBINED LOGISTICS IN THE CANADIAN CORPS, 1915-1918
}

\author{
submitted by \\ Michael Patrick Ryan, B.A. (Hons) \\ in partial fulfilment of the requirements \\ for the degree of Master of Arts
}

G.N. Hillmer, Thesis Supervisor

\author{
A.B. McKillop, Chair \\ Department of History \\ Carleton University
}

9 September 2005 


\begin{abstract}
As it fought on the Western Front, the Canadian Corps learned to maximize the potential of its support services by means of the combined logistics system. Because of the system's flexible nature, the Corps was able to offset the friction of war. If one mode of transport was interdicted, over-extended, or broken down, another could replace it. Efficient logistics in the battle area, including the construction of roads and tramways, contributed greatly to the Corps' striking power. Through combined logistics, the Corps was able to provide its fighting arms with the ammunition, rations, and equipment they required to undertake successful offensive operations. Logistics were crucial for the success of the Canadian Corps by the end of the First World War, being represented and required at every level.
\end{abstract}




\section{Acknowledgments}

This thesis could not have been written without my family's love and support. I would especially like to thank Dr. Norman Hillmer and Dr. Tim Cook. Without their encouragement, time, and expert advice, this thesis would not have been possible. I would also like to thank Dr. Kerry Badgley who initially encouraged me to pursue this topic, and Joan White for being helpful whenever I had any administrative questions. 


\section{Table of Contents}

Title Page

$\begin{array}{ll}\text { Abstract } & \text { ii }\end{array}$

Acknowledgments

Table of Contents iv

List of Appendices $\quad \mathbf{v}$

Introduction $\quad 1$

Chapter One

Adapting to the War of Materiel, 1915-1916 10

Chapter Two

Supplying the Set-Piece Battle: Vimy and Passchendaele, 1917

Chapter Three

The Combined Logistics System and the Last Hundred Days, $1918 \quad 94$

$\begin{array}{ll}\text { Conclusion } & 132\end{array}$

$\begin{array}{ll}\text { Bibliography } & 139\end{array}$

$\begin{array}{ll}\text { Appendices } & 147\end{array}$ 


\section{Appendices}

I General Scheme of Supply 147

II General Scheme of Supply, $1918 \quad 148$

III Light Railway, Tramway, and Lorry System, Vimy 149 


\section{Introduction}

Successful battles in a war of materiel, such as the First World War, were reliant on sound logistics that underpinned the strategic, operational, and tactical levels of war. ${ }^{1}$ In order to allow a military formation to come to grips with the enemy, roads and railways had to be available to move armed forces. Arrangements for the provisioning of men and horses were required, and networks that ferried ammunition and equipment to the fighting arms were essential in providing the means to fight. Bridges and billets needed to be constructed, lorries repaired, and material salvaged. Because of the enormous scope of the requirements of military forces, logistics are affected profoundly by the friction of war. While designed to overcome the difficulties presented by industrial warfare, logistics too are acted upon by the forces of friction. ${ }^{2}$ Time is always against the staff officer preparing for a rapidly approaching zero hour, and lengthening supply lines render transport duties ever more difficult when troops advance from their railheads. Often, logistics are deemed to have failed if there was not a true appreciation for war's frictions, which always hinder logistical endeavours.

\footnotetext{
${ }^{1}$ Strategy is defined as the art and science of using a state's military forces to secure the aims of national policy by applying force or the threat of force. It may also be defined as the broad plans for employment of military sea, land, and air forces. Tactics are defined as the action of giving battle or as the employment and maneuvering of forces to implement strategy. Operations is the level of warfare that lies between strategy and tactics (if defined by the size of the force, operations occur at the Corps level). Furthermore, operations is the level of conflict where military action has strategic goals that are one step removed from objectives that are political. See James F. Camsell, "From Normandy to the Scheldt. Logistics and the First Canadian Army (June-September 1944)," MA Thesis, University of New Brunswick, 1995, p. 2; Christopher Bellamy, The Evolution of Modern Land Warfare (New York: 1990), pp. 60-65.; K.T. Eddy, "The Canadian Forces and the Operational Level of War," Canadian Defence Quarterly vol. 21, no. 5, (April, 1992), pp. 19-20.

${ }^{2}$ Martin van Creveld, Supplying War: Logistics From Wallenstein to Patton (London: 1977), p. 231. Friction of war refers to the difficulties encountered by armed forces, including logistical services, that hinder their aims. These forces could be related to enemy action, poor terrain, the constraints of time and space, lack of communication and a whole range of other factors.
} 
This study focuses on logistics, which are defined as the provision of resources that support the operations and tactics of combat forces, including transportation for personnel, distribution of supplies, food and ammunition. The logistical services include mechanical transport (MT) or lorries, horse transport (HT), narrow-gauge railways including light railways and tramways, carrying parties or man packing, and those responsible for constructing infrastructure such as engineers, pioneers and labourers. The logistical services were employed in the combined logistic system in static warfare and, with a greatly increased tempo, in offensive operations.

The logistic system that ultimately emerged in the Canadian Corps was characterized by a mixture of resupply methods, including mechanical transport, horse transport, man-packing, and narrow-gauge railways. It was based on the British model, but throughout the war the Canadians learned from their experiences and gradually modified their Corps level logistics, which eventually resulted in a unique system within the British Expeditionary Force (BEF). While the British utilized similar modes of transport during the war, they were not used, in the case of light railways and tramways, to the same extent or with the same appreciation for logistical diversity and flexibility as they were in the Canadian Corps. As the war progressed, the Canadians realized that narrow-gauge railways, for example, were the most effective means to supply the Corps' heavy artillery with ammunition, whereas in areas that were frequently interdicted by German indirect fire, both motor transport and horse transport were the most effective means of supply. ${ }^{3}$ There was flexibility in the Canadian logistical approach: unforseen

\footnotetext{
${ }^{3}$ lan M. Brown, British Logistics on the Western Front (Westport, Conn.:1998), p. 173.
} 
difficulties brought on by the friction of war could be dealt with through a number of different transport modes. The Canadian Corps had realized fully by 1918 that logistical diversity and flexibility, hallmarks of the combined logistics system, were required in order to undertake successful offensive operations. It was through this system that the Canadians were adequately prepared and supported for the successful attacks at Vimy Ridge and the set-piece battles of 1918.

The Canadian Corps was re-organized in 1918 to enhance its striking power on the battlefield. With this goal in mind, the Corps' logistics system, which included supply and infrastructure construction, was fine-tuned as well. The combined arms solution to trench warfare was accompanied by a combined logistics approach. ${ }^{4}$ It is the contention of the present study that logistics were an important part of the Canadian offensive system. Canadian Corps commander Lieutenant-General Sir Arthur Currie realized that having sufficient engineers and labour to provide not only infrastructure, such as tramways, corduroy roads, and trench defences, but also combat engineering, would render the Corps much more efficient in offensive operations. Increased manpower for engineering work allowed supplies and ammunition to flow over the Canadians'

\footnotetext{
${ }^{4}$ The combined arms concept is based on different weapon systems acting in concert to create a powerful synergistic effect on the battlefield. This coordinated action far exceeds the force of any one arm working alone. See Bruce I. Gudmundsson, On Artillery (London: 1993), p. 160. Historians have argued that, by 1918, the Canadian Corps had not mastered combined arms warfare, but had become experts at an important element of it: a coordinated infantry-artillery attack, which featured a tight coordination between those two arms. Ian M. Brown calls this system the set-piece attack. Although in its infancy, the tank became integrated into the system, albeit less effectively. Air power was also becoming an important part of the system. See Shane B. Schreiber, Shock Army of the British Empire: The Canadian Corps in the Last 100 Days of the Great War (St. Catharines: reprinted 2004), p. 58; Ian M. Brown, "Not Glamorous, But Effective: The Canadian Corps and the Set-Piece Attack, 1917-1918," The Journal of Military History vol. 58, no 3 (July, 1994), p. 426; Tim Travers, How the War Was Won: Command and Technology in the British Army on the Western Front (London: 1992), p. 110.
} 
combined logistics system. The awareness that it was inefficient to over-tax one mode of transport could also be applied to manpower: the infantry could focus on training and war-fighting if they were not employed frequently as labour. Therefore, just as it took experience to realize that combined arms, with a heavy reliance on the protective and killing power of artillery, was the key to victory in trench warfare, it was through the very same experience that the Canadians realized combined logistics would deliver the materiel necessary to support the set-piece battles of 1918. The Canadian Corps was able to support the manpower of an oversized Corps through its logistical system as well as supply its impressive number of automatic weapons, infantry armaments, and artillery pieces with enormous quantities of ammunition.

The Canadian Corps, by 1918 , was similar to a miniature British army in size and capability, and more than capable of keeping itself supplied in the battle area. ${ }^{5}$ The combined logistics system provided the resources needed by the Corps to execute the successful limited objective set-piece battles of 1917 and 1918. The Canadians also realized that it was essential to provide not only the fire support for the infantry, but that logistics was crucial in allowing gains to be consolidated. Furthermore, the Corps, most notably by 1918 , had realized the importance of labour and engineers to be able to repair the carnage wrought by its own operational system and the enemy's efforts to destroy infrastructure.

Logistics issues on the whole have received scant attention from military historians. To date, there are only a few titles that deal with logistics issues in the First

\footnotetext{
${ }^{5}$ Shane Schreiber, Shock Army of the British Empire, p. 24.
} 
World War. George Thorpe's monograph addresses logistics theory, and was written to enable the United States military to consider supply problems as they became more involved in the First World War. Another work by Martin van Creveld analyzes the failure of the German's Schlieffen Plan in 1914 at the war's outset, and then goes on to consider the logistical issues of the Second World War, thereby neglecting the remainder of the First World War period. Julian Thompson's monograph also avoids dealing with the changes in the logistical infrastructure of the BEF and its formations. However, Thompson makes the accurate observation that the victories of the last Hundred Days were made possible by the changes to the BEF's logistical infrastructure during 19151917. These changes were necessary to maintain mobility in the period of rapid advance that characterized the battles in the final year of the war. Ian M. Brown expanded upon the idea of using logistics as a means to chart the evolution of the BEF during the First World War, and linked logistical and administrative excellence to the emergence of the limited objective set-piece attack in the BEF. Although he confines his study largely to the BEF, he does periodically delve into issues affecting the Canadian Corps. The only other work to evaluate logistics and administration in the BEF is A.M. Henniker's official history, which is an in-depth examination of the overall BEF logistics system. While it does offer some insight into Corps level logistics, its main focus remains the BEF itself. An important book, written by W.J.K. Davies, examines light railways and tramways on the Western Front. There are several instances where Davies emphasizes the Canadian Corps' proficiency in operating, constructing, and maintaining these narrow-gauge lines, 
but it does not explain the Corps' logistics system in much detail. ${ }^{6}$

There are two works that have, as their main focus, examined issues of logistics in the Canadian Expeditionary Force. The first, by Arnold Warren, is a regimental history of the Royal Canadian Army Service Corps, which uses a number of narratives and war diaries to describe the duties of the divisional trains and mechanical transport (MT) during the First World War. While helpful, the work does not adequately link logistics to operations. The second work, by Neal Porter, is a fine historical examination of logistics in the last Hundred Days (August to November 1918). It concludes that the Canadian Corps logistic system was not truly meant for open warfare, despite training, which, he argues, occurred in the last year of the war. Porter does not account for the evolution of the logistic system within the Canadian Corps during the first half of the war, nor does he incorporate aspects of engineering work, such as tramway construction, into his study. ${ }^{7}$

The Report of the Ministry: Overseas Military Forces of Canada, 1918, an official document prepared during the war, is an excellent source for the logistical and administrative functions of the CEF. It is a detailed compilation of the arrangement of the CEF's fighting arms as well as the activities of the lesser known logistical services. ${ }^{8}$

\footnotetext{
${ }^{6}$ Ian M. Brown, British Logistics on the Western Front (London: 1998), p. 10; George Thorpe, Pure Logistics (Washington: 1917, reprint 1986); Martin van Creveld, Supplying War: Logistics from Wallenstein to Patton (Cambridge: 1977); Julian Thompson, The Lifeblood of War (London: 1991); A.M. Henniker, Transportation on the Western Front, 1914-1918 (London: 1937); W.J.K. Davies, Light Railways of the First World War: A History of Tactical Rail Communications on the British Battlefronts, 1914-1918 (Newton Abbot: 1967).

${ }^{7}$ Arnold Warren, Wait for the Waggon: The Story of the Royal Canadian Army Service Corps (Toronto: 1961); Neal Porter, "From Trench to Open Warfare: The State of Logistics in the Canadian Corps, August to November 1918," MA memoire, University of Ottawa, 1998. For more on regimental histories see Tim Cook, “Literary Memorials': The Great War Regimental Histories, 1919-1939," Journal of the Canadian Historical Association vol. 13, (2003).

${ }^{8}$ Various, Report of the Ministry: Overseas Military Forces of Canada 1918 (London: 1919).
} 
However, it is not an analytical work and suffers from some organizational problems.

Another commissioned work, which is of particular importance for an examination of logistics in the CEF, is the first volume of A.J. Kerry and W.A. McDill's The History of the Corps of Royal Canadian Engineers Volume I, 1749-1939. The authors used official war records throughout the work and provide insight into the various logistical functions of the Corps' engineers: including road and tramway construction, bridging, and billet construction. $^{9}$

Although no recent study has focused on logistics, there are many glimpses of supply and transport issues in what historian Dave Campbell has labeled the "operational stream." ${ }^{10}$ These analytical works focus on the evolution of tactics, operations, doctrine, and structure of the Canadian Corps. ${ }^{11}$ Another important school of Canadian First World War historiography is the "popular school," which include works by historian Daniel

\footnotetext{
${ }^{9}$ A.J. Kerry and W.A. McDill, The History of the Corps of Royal Canadian Engineers, Vol 1 (Ottawa: 1962); Other official works include: G.W.L. Nicholson, Canadian Expeditionary Force, 1914-1919: The Official History of the Canadian Army in the First World War (Ottawa: 1962); G.W.L. Nicholson, The Gunners OfCanada. The History of the Royal Regiment of Canadian Artillery volume I, 1534-1919 (Toronto: 1967); A.F. Duguid, Official History of the Canadian Forces in the Great War, 1914-1919, General Series. Vol.1: Chronicle, August 1914-September, 1915 (Ottawa: 1938); Andrew Macphail, Official History of the Canadian Forces in the Great War, 1914-1919: The Medical Services (Ottawa: 1925). For more on Duguid and the official history see Wes Gustavson, "'Fairly Well Known and Need Not be Discussed' Colonel A.F. Duguid and the Canadian Official History of the First World War," Canadian Military History vol. 10, no. 2, (Spring, 2001).

${ }^{10}$ David C. G. Campbell, "The Divisional Experience in the C.E.F.: A Social and Operational History of the 2nd Canadian Division, 1915--1918," PhD Thesis, University Of Calgary, 2004, p. 3.

${ }^{11}$ See Bill Rawling, Surviving Trench Warfare: Technology and the Canadian Corps, 1914-1918 (Toronto: 1992); Shane B. Schreiber, Shock Army of the British Empire: The Canadian Corps in the Last 100 Days of the Great War (St. Catharines: reprinted 2004); Tim Cook, No Place to Run: The Canadian Corps and Gas Warfare in the First World War (Vancouver: 1999); Ian M. Brown, "Lieutenant-General Sir Arthur Currie and the Canadian Corps 1917-1918: The Evolution of a Style of Command and Attack," MA Thesis, University of Calgary, 1991; Ian M. Brown, "Not Glamorous, But Effective: The Canadian Corps and the Set-piece Attack, 1917-1918," Journal of Military History vol. 58, no. 3 (1994); Peter Dennis and Jeffrey Grey (eds.), 1918: Defining Victory (Canberra: 1998); J.L. Granatstein, Canada's Army. Waging War and Keeping the Peace (Toronto: 2002).
} 
Dancocks. His campaign studies offer well researched, patriotic treatments of several key battles, and are valuable tools that shed light on operations and, at times, touch on logistics. ${ }^{12}$ Dancocks also contributed to the "biographical school," which remains focused primarily on Sir Arthur Currie and only rarely delves into logistical issues. ${ }^{13}$ Other officers of the CEF have received treatment, one was a prominent logistician, but none of their biographies give detail in this area. ${ }^{14}$

Of the aforementioned works, none have examined the evolution to combined logistics or used logistics as a means to examine the learning curve in the Canadian Corps. This work will examine logistics, and how it related to the Corps' fighting efficiency, in three chapters. The first will deal primarily with logistical issues prior to and during the Second Battle of Ypres in 1915, along with developmental changes during the Somme battles. Chapter 2 will focus on the build-up for and consolidation during the battle of Vimy Ridge in April 1917, followed by an analysis of the Canadian Corps' logistical operations at Passchendaele in October and November of that same year, and how they contributed to the successful attainment of the Corps' objectives. The final chapter will explain the importance of the reorganization of the Canadian Corps logistical services and how corresponding improvements to the combined logistics system led to

\footnotetext{
${ }^{12}$ Daniel Dancocks, Legacy of Valour (Edmonton: 1986); Spearhead to Victory (Edmonton: 1987); Welcome to Flanders Fields (Toronto: 1988); Pierre Berton, Vimy (Canada: reprint, 2001); Marching As to War. Canada's Turbulent Years, 1899-1953 (Canada: reprint, 2002).

${ }^{13}$ Daniel Dancocks, Sir Arthur Currie: A Biography (Toronto: 1985); H.M. Urquhart, Arthur Currie: The Biography of a Great Canadian (Toronto: 1950); A.M.J. Hyatt, General Sir Arthur Currie (Toronto: 1987).

${ }^{14}$ Other biographies include: John Swettenham, McNaughton, Vol.1, 1887-1939 (Toronto: 1968); Jeffrey Williams, Byng of Vimy: General And Governor General (Toronto: 1992); Atholl Sutherland Brown, Buster. A Canadian Patriot and Imperialist. The Life and Times of Brigadier James Sutherland Brown (Waterloo, Ontario: 2004). This is the exception, although Brown offers little on logistics.
} 
the battlefield successes that followed at Amiens, the Canal du Nord, and Valenciennes. Logistics are essential to understand the Canadian Corps set-piece battle. While historians have examined tactical and doctrinal evolutions, they have not studied the combined logistics system. Logistics did not, in and of itself, win battles, but the system that evolved in the Canadian Corps enabled it to become an elite force on the Western Front. 


\section{Chapter One}

\section{Adapting to the War of Materiel, 1915-1916}

On 20 February 1915, the British Expeditionary Force's Commander-in-Chief, Field Marshal Sir John French, inspected the units of the $1^{\text {st }}$ Canadian Division and declared that they were fit for service. Before French's tour reached its conclusion, the $1^{\text {st }}$ Canadian Division was ordered to take over a portion of the First Army's front. On 3 March, the division arrived in the front line trenches in front of Fleurbaix, south of Armentieres, and took over 6,400 yards of trench. ${ }^{15}$ After weeks of trench warfare and steadily losing men to shells and snipers, the Canadians were soon on their way to the Ypres Salient. This was the beginning of a journey that would later lead them to fight through the trials of the Somme, Vimy, Passchendaele, and the last Hundred Days. It would be through these experiences that the logistic system would develop and evolve into one that, while not without its problems, was one of the best Corps level organizations on the Western Front.

The Canadians began moving, by brigades, to Ypres in London double-decker buses. They disembarked at Vlamertinghe, and then marched by battalions at half-hour intervals through the towns of Ypres and Wieltje. The Canadians were met by guides from the outbound French $11^{\text {th }}$ Division who conducted them into the frontlines. ${ }^{16}$ Orchestrating a relief of another division was always fraught with logistical difficulties as incoming units were led to their new positions. For example, a party from the $7^{\text {th }}$

\footnotetext{
${ }^{15}$ G.W.L. Nicholson, Canadian Expeditionary Force, p. 49.

${ }^{16}$ Daniel Dancocks, Welcome to Flanders Fields The First Canadian Battle of the Great War: Ypres, 1915 (Toronto: 1988), p. 99.
} 
Battalion was assigned a French soldier to guide them to their new location. He led the Canadians through fields, ditches, barbed wire entanglements, over fallen trees, into ruined houses containing dead bodies and down decrepit communication trenches before he announced that he had lost his way. All the while, the heavily laden soldiers were subjected to small arms fire. ${ }^{17}$ There were other logistical difficulties to overcome such as the handover of supplies and trench stores, which will be discussed later in this study.

When the $1^{\text {st }}$ Canadian Division's relief of the French $11^{\text {th }}$ Division was completed between 14 and 17 April 1915, the Canadians found themselves in a sector 4,500 yards in length that ran alongside the Stroombeek, a northern tributary of the Steenbeek river. Directly behind the Canadian front line, at a distance of approximately 1,500 yards, was Gravenstafel Ridge, whose name coincided with a hamlet that lay on the right of the divisional area. Before the infantry went into the front line, selected engineer and staff officers had been sent to reconnoitre and report on conditions. ${ }^{18}$ They were surprised to find the sector in a poor state: trenches had not been connected or protected against enfilade fire, breastworks had been poorly constructed, and, in the case of the $2^{\text {nd }}$ Brigade's sector, side trenches and shell holes had been used as latrines and burial places. Similarly, the $3^{\text {rd }}$ Brigade's sector was littered with dead bodies, some half-buried and others left in the open. ${ }^{19}$

The sector required improvement to alleviate sanitation, safety, defensive and logistical problems. Because of the high water table in the area, it was often difficult for

\footnotetext{
${ }^{17}$ Ibid, p. 101.

${ }^{18}$ A.F. Duguid, Official History of Canadian Forces in the Great War, 1914-1919 v.1, p. 210.

${ }^{19}$ G.W.L. Nicholson, Canadian Expeditionary Force, p. 57.
} 
the field companies of engineers, supplemented by infantry on fatigue duty, to deepen trenches. Despite these conditions, and through considerable effort, improvements to defensive works and drainage were made in the coming days. The ability of the Canadians to move within the sector was also limited: the French, who had previously occupied the area, managed their movements over the Yser Canal west of Brielen over a single trestle and barge bridge. Sensing the difficulties this would cause to logistics and communications, the Canadian Engineers set about constructing new foot-bridges and a horse-traffic bridge without delay. ${ }^{20}$

The engineers at this time were organized into field companies of approximately 140 all ranks, and the $1^{\text {st }}$ Canadian Division contained three such field companies in 1915. They were each divided into three sections (these would be renamed "platoons" in the Second World War). The primary tasks undertaken by engineers at this time included the upkeep of defensive positions, including the construction and maintenance of various types of trenches, the draining of trenches that had filled with water, and the building of breastworks in areas where digging was problematic because of sodden terrain. Engineers were also tasked with erecting barbed wire entanglements and similar obstacles. They built dug-outs, shelters, and bomb storage sites as well as machine gun and artillery emplacements. They would later construct and operate tramways that transported ammunition and supplies to different points along the front. ${ }^{21}$

\footnotetext{
${ }^{20}$ A.J. Kerry and W.A. McDill, History of the Corps of Royal Canadian Engineers vol. 1, p. 89; War Diary, $1^{\text {st }}$ Brigade, Canadian Engineers, LAC, RG 9, III D3, vol. 4990, microfilm, reel T-10824, file 639, 19 April 1915, p. 7.

${ }^{21}$ Bill Rawling, Technicians of Battle (Toronto: 2001), p. 19.
} 
These engineers were a part of the $1^{\text {st }}$ Canadian Division, which numbered 18,000 men and over 5,000 horses. ${ }^{22}$ The division was organized into three infantry brigades; each brigade consisted of four battalions of 1,000 men each. Each infantry brigade was supported by one brigade of field artillery comprised of 4 four-gun batteries, a brigade ammunition column, which was under the control of the artillery, the field company of engineers, a signals section, and one company of the divisional train. Furthermore, a brigade field ambulance, which consisted of seven ambulances, was provided at a later date. In addition to the Brigade Ammunition Columns (BACs), the division also contained a Divisional Ammunition Column (DAC), a horse transport unit that hauled ammunition for both the artillery and the infantry. ${ }^{23}$

Along with the DAC, Divisional Train, and engineers, there were other units that provided logistical support. The Divisional Supply Column (DSC) and the Divisional Ammunition Park (DAP) were mechanical transport (MT) units that used lorries to move supplies and ammunition for the division. The Railway Supply Detachment and four depot units of supply were units that operated on the BEF's lines of communication (L. of C.). ${ }^{24}$ The L. of C. referred to the supply lines that ran from the main bases at French ports to the rear limit of administration by formation commanders in the field. Materiel and stores not only flowed along this network of railway lines and roads, but were

\footnotetext{
${ }^{22}$ Kenneth Radley, "First Canadian Division, C.E.F., 1914-1918: Ducimus (We Lead)," PhD Thesis, Carleton University, 2000, p. 46.

${ }^{23}$ Arnold Warren, Wait for the Waggon, p. 81

${ }^{24}$ A.F. Duguid, Official History of Canadian Forces in the Great War, 1914-1919 v.1. p. 153. A field butchery and field bakery, which both crossed in May, would also remain on the lines of communication.
} 
stockpiled at locations near the ports, and at points along the L. of C. ${ }^{25}$ The means of transport that negotiated these supply lines were also part of the L.of C. The BEF's L. of C. terminated at the standard-gauge railhead. ${ }^{26}$ From this point onwards, mechanical transport took over. The mechanical transport (MT) of the division was comprised of lorries, which formed part of the Canadian division. Later, the $1^{\text {st }}$ Canadian Division would form part of the Canadian Corps. Light railways emerged as a prime mover of commodities later on during the 1916 Somme battles, but in 1915 MT was the main link between railhead and the refilling points from where horse transport took over. Although some of the units that worked on the BEF's L. of C. were Canadian, they did not, for the most part, form part of the $1^{\text {st }}$ Canadian Division (or later Canadian Corps), and were under control of the BEF in France.

Other units would become part of the $1^{\text {st }}$ Canadian Division, such as the Reserve Park, which crossed on 26 April. The Reserve Park, a horse transport unit, ${ }^{27}$ was typically stationed thirty miles behind the lines with three days iron rations and forage for every soldier in the division. The reserve parks were organized in anticipation of a war of movement, but with the advent of trench warfare the parks had little to do until early 1916. At this time, they were ordered to dispense with their rations, organized into sections and tasked with different types of transport work. Essentially, the Reserve Park

\footnotetext{
${ }^{25}$ Roger G. Miller, "The Logistics of the British Expeditionary Force, 4 August to 5 September 1914," Military Affairs vol. 43, no. 3 (Oct., 1979), p. 133; E.L.M Burns, "Protection of the Rearward Services and Headquarters in Modern War," Canadian Defence Quarterly vol. X, no. 3 (April, 1933), p. 295.

${ }^{26}$ Exceptions to this general rule will be discussed later on.

${ }^{27}$ The Reserve Park consisted of approximately 300 all ranks, 360 horses, and 100 general service (GS) wagons.
} 
was a floating reserve of horse transport, which unlike the divisional train, did not have regular daily assignments and could be employed where they were needed most. ${ }^{28}$

Although the DAC was an artillery unit, its horse transport ${ }^{29}$ was part of the supply chain that furnished all units of the $1^{\text {st }}$ Canadian Division with ammunition, including the infantry. Ammunition supply on the divisional level could be described as a step-by-step process: ammunition was transported to railhead by army personnel. Once there, it was picked up by Divisional Ammunition Park (DAP) lorries, and forwarded to ammunition dumps. ${ }^{30}$ After the DAP lorries had conveyed the ammunition to the dump, ammunition was then transported by the DAC to refilling points. From these refilling points, the Brigade Ammunition Columns (BACs) would transport the ammunition to their brigade artillery batteries and to dumps accessible to infantry carrying parties. These were usually within the range of enemy artillery fire, and were therefore camouflaged or stored underground. Finally, small arms carts were used in small arms ammunition (s.a.a.) forward supply, when possible, but ammunition was often carried in by hand. ${ }^{31}$

Captain F.B. Eaton was responsible for the administration of the Depot Units of

\footnotetext{
${ }^{28}$ David W. Love, $A$ Call to Arms. The Organization and Administration of Canada's Military In World War One (Calgary: 1999), p. 220.

${ }^{29}$ Later, two of the regular D.A.C.s were equipped with a few motor lorries as an experiment.

${ }^{30}$ War Diary, 1st Canadian Divisional Ammunition Sub-Park, LAC, RG 9, III D3, volume 5022, file 799, microfilm, reel T-10907, 7 February 1915. The DAP had a strength of 5 officers, 324 other ranks, 64 Canadian Field Artillery (C.F.A.) other ranks, and 1 interpreter. Vehicles at the DAP's disposal were: 76 lorries, 4 motor cars, 4 workshops, 4 trailers and 9 motor cycles. When it first arrived on the continent on 7 February 1915, the 400-man DAP had a number of vehicles at its disposal.

${ }^{31}$ Lieutenant-Colonel C.E. Long, "Ammunition Supply During the Great War With Special Reference to the $1^{\text {st }}$ Canadian Division," Canadian Defence Quarterly vol. V, no. 2 (January 1928), p. 153. It must be noted that in May of 1916 the $1^{\text {st }}$ Canadian D.A.C. was reorganized and the Brigade Ammunition Columns (BAC.s) were absorbed into the D.A.C.. The intention was to eliminate redundancy in the supply chain and make the system more efficient on the divisional level. This is described in C.E. Long's article on p. 156.
} 
Supply. His men worked closely with British elements and supervised the off-loading of supply ships at Boulogne (the Base Supply Depot), accounted for supplies, and loaded daily "pack trains". ${ }^{32}$ A "Pack" contained a set of complete rations for a formation, and its size was in accordance with its strength in men and horses. ${ }^{33}$

Pack trains, therefore, contained the daily allotment of groceries, bread, meat, fuel, forage and sundries for one division. They were placed in railway trucks or cars at different depots depending on the commodity. Each railway truck or car bound for the $1^{\text {st }}$ Division, for example, was clearly marked, and when they reached a regulating station all cars for the $1^{\text {st }}$ Division were linked to the same train and were sent forward to railhead. ${ }^{34}$ One train would transport the daily requirements for maybe one or two divisions. An officer from the Depot Units of Supply would have accompanied the train on its journey to railhead, and upon reaching its destination, he would then entrust the supplies to the Officer Commanding (OC) the Railhead Supply Detachment. The detachments consisted of sixty-two all ranks, were stationed at broad-gauge railheads and were tasked with unloading and accounting for supplies from the daily pack trains. These broad-gauge railheads were typically located ten to twenty miles from the front lines. ${ }^{35}$ The OC of the Railhead Supply Detachment would receive the supplies, and then divide them into allotments for each of the three infantry brigades of the $1^{\text {st }}$ Canadian Division in addition

\footnotetext{
${ }^{32}$ Arnold Warren, Wait for the Waggon, pp. 84-85; For information on the system of loading pack trains see Lieut-Colonel Sutherland Brown to $1^{\text {st }}$ Canadian Division et al., 2 June 1916, LAC, RG 9, III C1, vol. 3885, folder 34, file 6, "Pack Trains (System of Loading)."

${ }^{33}$ Various, Overseas Military Forces of Canada, p. 320.

${ }^{34}$ Railhead: farthest point reached by the railway. Point on the railway at which road transport of goods begins.

${ }^{35}$ David W. Love, $A$ Call to Arms, p. 218.
} 
to its divisional troops. ${ }^{36}$ After they were divided, the supplies would then be turned over to the Divisional Supply Column (DSC).

Although the DSC was similar to the DAP, it was not responsible for ammunition delivery, but for hauling supplies from the Pack Train. The DSC had a strength of roughly 300 men and was an MT unit with a number of motor vehicles at its disposal. ${ }^{37}$

Throughout the war, the O.C. of the supply column required several additions to adapt to changing divisional requirements in France that included seven additional heavy lorries, thirty additional 30-cwt lorries, an additional workshop and two store wagons. All the lorries in the unit were "White's," a nickname given to vehicles manufactured by the White Company ${ }^{38}$ After the supplies were divided, the DSC would then transport them to designated rendezvous points that would have been established by each of the four companies of the divisional train. Guides from each of the companies of the Divisional Train would have met the lorries and directed them towards the company refilling points. ${ }^{39}$

As a horse transport (HT) unit, the $1^{\text {st }}$ Canadian Divisional Train's ${ }^{40}$ duties included the receiving and transportation of supplies to the units of a division. It also

\footnotetext{
${ }^{36}$ Arnold Warren, Wait for the Waggon, pp. 84-85; A.F. Duguid, Official History of The Canadian Forces in the Great War 1914-1919 vol. 1, p. 211. While in the Ypres salient, the 1st Canadian Division drew supplies from the railhead at Vlamertinghe

${ }^{37}$ A.F. Duguid, Official History of the Canadian Forces in the Great War 1914-1919 vol. 1, Chronology, Appendices and Maps (Ottawa: 1938), p. 158. The unit consisted of 37 three-ton lorries, 5 thirty-cwt lorries, a workshop, bicycles and a few spare cars.

${ }^{38}$ Major F. Lindsay Lloyd, R.E. Commanding M.T. Depot to D.A.D.T, 19 January 1915, in A.F. Duguid Chronology, Appendices and Maps, p. 151-152.

${ }^{39}$ Arnold Warren, Wait for the Waggon, p. 85.

${ }^{40}$ A.F. Duguid, Chronology, Appendices and Maps, p. 158. As of 10 February 1915 had a strength of 28 officers, 411 other ranks, and 384 horses.
} 
carried each unit's personal and technical baggage. The Divisional Train was comprised of a headquarters and four companies. Company No. 1, or Headquarters company, was more than twice the strength of each of the remaining three companies. It was given the task of moving rations and baggage for the Divisional Troops. The other three companies (numbers 2,3, and 4) of the Divisional Train were each responsible for rations and handling the baggage for one infantry brigade (each brigade was considered to be a "ration group"). Each company had artificers, saddlers, wheelers and farriers who kept wagons and harnesses functioning and ensured that horses were shod properly. ${ }^{41}$

The supplies onboard the lorries from the Divisional Supply Column (DSC) would be dropped off at the Refilling Point. This could have been at the side of the road, in a field or another location that best suited the requirements of the Divisional Train. The supply lorries of the DSC dumped their cargo at designated spots at the Refilling Point: meat and forage were usually put together while bread, vegetables and potatoes were placed in a separate spot. There would generally be two supply wagons for each infantry battalion. The supply captain of the Divisional Train was responsible for subdividing the supplies according to the requirements of each battalion. The wagons of the Divisional Train would then load the commodities required by their battalion. The Divisional Train would later proceed to the Battalion Quartermaster Stores which, on average, would be

\footnotetext{
${ }^{41}$ David W. Love, "A Call to Arms"'The Organization and Administration of Canada's Military In World War One (Calgary: 1999), p. 221. The train headquarters had a commanding officer, a senior supply officer (who was second in command), an adjutant, a veterinary officer, a medical officer, a paymaster, a postal clerk and a few support staff. The train's companies were organized into three parts: Headquarters, Supply, and Supply and Baggage Transport sections, each had an officer and two non-commissioned officers attached to it.
} 
located two miles away. ${ }^{42}$

When a battalion moved into the line, the transport and Quartermaster's stores remained behind along with Rear Battalion Headquarters. They were jointly responsible for supplying the battalion each day with food and, when necessary, clothes, ammunition, rum, mail, and reinforcements. The men who belonged to these sections did not come into contact with the enemy in the same manner that the front-line soldier did, but their work was difficult and dangerous.

The transport lines, where the quartermaster stores were normally located, were often shelled by enemy heavy artillery ${ }^{43}$ Every night, rations were carried to the battalion in the line, and the roads and pathways along which transport traveled were often subjected to machine gun and artillery fire. The quartermaster received the supplies, and then divided them into allotments for each of the four companies of the battalion. The company quartermaster-sergeant, who would also have been present, usually brought with him a limbered wagon, a cook and a driver. Each company quartermaster-sergeant further divided his allotment into a portion for each of his four platoons, usually around 50-60 men. Typically, each platoon's portion would be placed in a sack that could be managed by one man. Slight variations of this method occurred as well: according to Private Donald Fraser, the procedure involved placing the rations for one platoon in two sandbags that were tied together and placed on the carrier's shoulder. Each pair of sandbags was labeled with a small wooden tag that had one, two, three or four notches in

\footnotetext{
${ }^{42}$ Arnold Warren, Wait For The Waggon, p. 86.

43،"The Adjutant," The 116 $6^{\text {th }}$ Battalion in France (Toronto: 1921), p. 47.
} 
it that indicated which rations were for each platoon. ${ }^{44}$ The portions were then placed in the company wagons' compartment with the supplies for number 1 and 2 platoons in the forward half of the compartment while the portions for 3 and 4 platoons took up the bottom half. At sunset, the Companies' wagons departed from the Quartermaster's stores and headed towards the Advanced Depot that was located near the front. ${ }^{45}$

During the $1^{\text {st }}$ Canadian Division's stay in the Ypres Salient, rations and other supplies were brought forward from the Advanced Depot by carrying parties composed of men from the battalions in the line.$^{46}$ Each company commander would have detailed men from his unit to form a ration party in the afternoon, usually consisting of one noncommissioned officer and six to eight men. This party would travel on foot to the unit's Advanced Depot and retrieve the supplies from the company quartermaster sergeant. The journey of the ration party began in the afternoon so that the return trip could be made under the cover of darkness. The ration party's return at approximately midnight allowed the companies of the line to be at optimum strength for the most dangerous time of the night. Shortly after daybreak, each platoon sergeant distributed his platoon's supplies to section corporals, who in turn handed the rations over to the men. The grateful or grouchy front-line troops cooked their meals on improvised or manufactured Tommy cookers. ${ }^{47}$

At the war's outset, few manufactured Tommy cookers were available to the men.

\footnotetext{
${ }^{44}$ Donald Fraser, The Journal of Private Fraser (Nepean, Ontario: 1998), p. 79.

${ }^{45}$ Arnold Warren, Wait For The Waggon, p. 86.

${ }^{46}$ F.R.Phelan, "Army Supplies in the Forward Area and the Tumpline System," Canadian Defence Quarterly vol. VI, no. 1 (October 1928), p. 32; Reprinted in Canadian Military History vol. 9, no. 1, Winter 2000, pp. 31-45.

${ }^{47}$ David W. Love, A Call To Arms, p. 217.
} 
These little stoves usually consisted of a small tin holding a chunk of solid fuel or a pot of methylated spirit ${ }^{48}$ on which mess tins full of water or tinned food were heated. Gerald Borgoyne, a British soldier, described a field canteen purchased by the officers of his company in 1915: it consisted of a box fitted with plates, cups, coffee pot, and a primus stove, which he deemed to be a "joy for ever." Those who were not able to buy manufactured stoves innovated: one British corporal in particular placed lit flannelette cloths (meant for cleaning rifles) that had been soaked in whale oil (used for foot care) inside a used tin to brew tea. Later on, this same innovator used an ammunition box to brew multiple cups of tea in a similar fashion. ${ }^{50}$ Not unlike his British counterpart, a Canadian pioneer of the $72^{\text {nd }}$ Battalion, Private A.E. McGubbin, fashioned a Tommy cooker from a pork-and-beans can along with the flammable mix of sacking and fat. McGubbin's clever invention was widely adopted by other Canadian units on the Somme. ${ }^{51}$

Canadian and British soldiers even attempted to use their helmets in impromptu cooking operations. This practice was common enough to warrant a reaction from the War Office: "I am to point out that if a structure of steel of the quality used for steel helmets is subjected to the heat of a cooking fire, the protective value of the metal will be entirely ruined...the use of steel helmets for any other purpose than that for which they are

\footnotetext{
${ }^{48}$ methylated spirit: a form of alcohol used as a solvent and for heating.

${ }^{49}$ Richard Holmes, Tommy: The British Soldier On the Western Front 1914-1918 (London: 2004), pp. 316-317.

${ }^{50}$ Ibid, p. 317.

${ }^{51}$ G.W.L. Nicholson, Canadian Expeditionary Force, p. 189 ; originally from Bernard McEvoy and A.H. Finlay, History of the $72^{\text {nd }}$ Battalion Seaforth highlanders of Canada (Vancouver, 1920), pp. 24-25.
} 
intended is strictly prohibited. ${ }^{.52}$ It is unclear whether or not the reprimand was heeded by those at the front.

Later in the war, a version of the Tommy cooker made of grease and wick was adopted by some units of the $4^{\text {th }}$ Canadian Division for emergency purposes. It was carried with the units' iron rations and used only in times of need. The cover of the cooker was in the form of an envelope that had been folded down and soldered. When it was opened with a knife, the cover could be bent to form a rest for a mess-tin. The cooker could burn for one and a half hours, and was capable of bringing two mess-tins of water to boil. ${ }^{53}$ While food preparation has remained largely ignored topics by historians, it was essential to the morale of the soldier. Even in quiet sectors on the Western Front, where trench fighters engaged in tacit truces and ritualized aggression, conditions in the trenches were cold, dirty, and wet much of the time. ${ }^{54}$ Food, in addition to being a daily physical necessity, also served to bolster morale and acted as a means to strengthen social ties in an otherwise depressing environment.

In November of 1915, the $2^{\text {nd }}$ Canadian Infantry Brigade assessed how some of its battalions were preparing their rations. In the $5^{\text {th }}$ Battalion, for instance, men received a hot meal everyday in the trenches. It was cooked in the regimental cookers and then transported into the line by the ration party at night, to be warmed over Tommy cookers

\footnotetext{
${ }^{52}$ B.B. Cubitt to C. Twidale, 2 August 1916, LAC, RG 9, III C 9, vol. 4530, file 8, "Helmets. War Office Letter Re. Use of."

${ }^{53}$ Lt. Col. KP Marshall to Canadian Corps 'Q', 13 May 18, LAC RG 9, III C1, vol. 3893, folder 55, file 20, "Trench Food Heaters"; " $46^{\text {th }}$ Division - Trench Food Heater," 31 May 1917, in ibid.

${ }^{54}$ Niall Ferguson, The Pity of War (New York: 1999), pp. 342-343; Tony Ashworth, Trench Warfare 1914-1918. The Live and Let Live System (London: 1980), pp.119-122.
} 
by the men. In the $7^{\text {th }}$ Battalion, meat and potatoes were cooked at the field kitchen, ${ }^{55}$ sent in cold and reheated. Bacon was often brought forward uncooked, and was prepared by sections and then distributed. The company in the 7th's reserve trenches had their meals cooked in the field kitchens and were brought forward in dixies. ${ }^{56}$ In the $8^{\text {th }}$ Battalion, arrangements were made for a hot meal to be sent up to each company at midday or "stand down" in the evening. The arrangements for the issuing of meals was controlled by the commanding officer of each company. ${ }^{57}$

In case units were not getting hot food in the trenches, Major-General A.A. Chichester, Assistant Adjutant and Quartermaster General (DA and QMG) of the British Second Army, forwarded sketches of an insulated box for transporting meals and a similar vessel for transporting water to the Canadian Corps. Box A is representative of a wooden case upholstered with strong canvas or cloth and stuffed with clean, dry straw. The top, bottom and sides were made large enough for a cooker dixie to go inside without difficulty. Two rope handles were attached to each side through which carrying poles were fitted. The lid was similarly upholstered and should have been designed to fit snugly on top of the case. The box required two men to handle it, and was capable of keeping dinners hot for four hours and allowed the meal to be consumed without any further

\footnotetext{
${ }^{55}$ A horse drawn wheeled-cooker complete with dixies, pots and heated by a fire contained below. One was allotted per company. See Richard Holmes, Tommy: The British Soldier on the Western Front, pp. 314315.

${ }^{56}$ dixie: a large iron pot in which stew or tea is made.

${ }^{57}$ Captain S.P. Mackenzie to Headquarters $1^{\text {st }}$ Canadian Division, 27 November 1915, LAC, RG 9, III C1, vol. 3879, folder 14, file 7, "Food Containers to Retain Heat (report on)."
} 
heating. ${ }^{58}$ The second box was designed in much the same way as box A, but an empty tea canister was used to hold water within it. The top and sides of the box were perforated with $1 / 4$ " holes and the straw had to be wetted daily. The container kept 6 gallons of water clean and cold. ${ }^{59}$

These types of containers were advantageous for keeping food warm for men who were absent or on duty at mealtimes. They also allowed for the conservation of fuel because meals would remain warm and did not require further heating. After trials were conducted in the $1^{\text {st }}$ Canadian Division, however, it was recommended that such containers be made trench stores, because it was difficult to carry them around, and that in many cases the men preferred to do their own cooking. ${ }^{60}$ The importance of food in the day to day operations of any fighting force is often overlooked. Without their 3,000 or 4,000 calories per day, soldiers would certainly lose their value as engineers, labourers and fighting men. ${ }^{61}$ In addition, much of the mobility of a division in the First World War required horses and without their daily fodder, they too would be unable to function. The men and horses, who were the end consumers of food, were supported, even in 1915, by an intricate yet very necessary logistics system, without which the Canadians would have been unable to fight.

\footnotetext{
${ }^{58}$ Major-General A.A. Chichester to Canadian Corps, 24 November 1915, LAC, RG 9, III C1, vol. 3879, folder 14, file 7, "Food Containers to Retain Heat (Reports On)".

${ }^{59}$ Ibid.

${ }^{60}$ Staff Captain, $3^{\text {rd }}$ Canadian Inf. Bde, to $1^{\text {st }}$ Canadian Division, 23 January 1916, LAC, RG 9, III C1, vol. 3879, folder 14, file 7, "Food Containers to Retain Heat (Reports On)"; Major General Arthur Currie $1^{\text {st }}$ Canadian Division to Canadian Corps, 5 January 1916, LAC, RG 9, III Cl, vol. 3879, folder 14, file 7 "Food Containers to Retain Heat (Reports On)".

${ }^{61}$ Martin van Creveld, Supplying War. Logistics from Wallenstein to Patton, (London: 1977), p. 1.
} 
The preparation of food, the transportation of ammunition, and just about every aspect of a soldier's daily routine, was complicated profoundly by enemy offensive action. Such was the case at Ypres on 22 April 1915. After months of preparation, German gas units released 160 tons of chlorine gas from 5,730 canisters towards the $87^{\text {th }}$ French Territorial Division and the $45^{\text {th }}$ Algerian (Colonial) Division, both of whom were located to the left of the $1^{\text {st }}$ Canadian Division's position. The Canadians initially thought that the greenish-yellow gas cloud was a new form of gun powder that had been used to fire conventional shells at the French, but those considerations were soon dispelled as choking Algerians stumbled near the Canadian lines. After being inhaled, chlorine gas attacked the victim's lungs by causing the membranes of the bronchial tubes to swell. The congested lungs failed to take in oxygen and caused the victim to suffocate. ${ }^{62}$ The field artillery of the nearby British $27^{\text {th }}$ Division reported that "fumes blowing over from the scene of the fighting made the eyes very painful.." ${ }^{63}$ Major H.H. Matthews, who was in command of No.2. company, $8^{\text {th }}$ Canadian Infantry Battalion during the battle, stated that the least exertion on behalf of soldiers, who had been exposed to the gas, brought about convulsion-like choking fits. ${ }^{64}$ Because they were in the densest part of the gas cloud, the French broke and ran in the face of this fearsome new weapon, which resulted in a mile long gap in the allied line.

\footnotetext{
${ }^{62}$ Tim Cook, No Place to Run: The Canadian Corps and Gas Warfare in the First World War (Vancouver: 1999), p. 21.

${ }^{63}$ War Diary, 27th Division, 22 April 1915, LAC, RG 9, III, D3, vol. 507 , microfilm, reel T-11349.

${ }^{64}$ Col. H.H Matthews, "An Account of the Second Battle of Ypres, April, 1915, being the experience of a Company Commander prior to and during the fighting" Canadian Defence Quarterly vol. 1, no. 3 (April 1924), p. 39.
} 
The gas attack of 22 April 1915 preceded a large conventional assault, which made " $Q$ " staff work even more essential especially in regard to the supply of s.a.a. and bombs to the trenches. Later in the war, staff at Corps headquarters would consist of three branches: G, A, and Q. The General Staff or "G" branch was concerned mainly with fighting, and as a result had several duties. The Adjutant-General's Branch or " $\mathrm{A}$ " dealt primarily with issues surrounding personnel..$^{65}$ "Q" branch of the staff managed a range of supply, equipment and housing issues. Included in that wide sphere of responsibilities was supply of food and forage, ammunition and water supply, fuel, housing of troops, billeting, hutting and tents, traffic control, baths, trophies of war, provision of horses, veterinary services, salvage, stores, clothing, equipment and transport. Moves undertaken by the entire Corps were coordinated and arranged by "Q" branch that made up the administrative arrangements and coordinated the move. ${ }^{66}$ At the divisional level, the basic staff organization was essentially the same except for lower rank levels. The "G" branch officer at division was a General Staff Officer 1 (GSO1). For issues regarding logistics, the Assistant Adjutant \& Quartermaster General (AA \& QMG) was responsible. The logistician at the brigade level was a Staff Captain. ${ }^{67}$

As far as administrative work was concerned, during the $2^{\text {nd }}$ Battle of Ypres, one war diary stated that "during the engagement the supply of food and ammunition worked

\footnotetext{
${ }^{65}$ "G" Branch's duties included: operations, plans, policy, operational movement, communications training and intelligence. " $\mathrm{A}$ " Branch's duties included pay, promotion, records, discipline, confinement, law, personnel appointments, medical matters, burying casualties, and discharges. Kenneth Radley, "First Canadian Division, C.E.F., 1914-1918: Ducimus (We Lead)," pp. 74-75.

${ }^{66}$ Various, Overseas Military Forces of Canada, pp. 316-317.

${ }^{67}$ Kenneth Radley, "First Canadian Division, C.E.F., 1914-1918: Ducimus (We Lead)," pp. $77,79$.
} 
without a hitch and there is nothing particular to report on these services. ${ }^{968}$ However, despite this cursory account, during the chlorine gas attack, Major (later Colonel) Sutherland Brown of the "Q" Staff of the $1^{\text {st }}$ Canadian Division realized that the Brigade Ammunition Columns, with their preoccupation to keep the artillery batteries supplied with ammunition, neglected to supply the infantry with their s.a.a. and bombs. Brown took matters into his own hands by commandeering one of the brigade ammunition columns at Brielen, which was behind the lines. From here, he personally directed the supply of s.a.a. and bombs for the infantry. The remaining two BACs were left to their duties of supplying the batteries of the field artillery. These columns also had, as one of their main duties, to supply the British guns along with their other duties of supplying their own artillery batteries and the infantry brigades with ammunition. ${ }^{69}$ Despite the intensity of the fighting, the $1^{\text {st }}$ Canadian DAC managed to maintain the supply of ammunition during the battle:

An order came at 8:10 pm from Canadian Divisional Artillery Headquarters to send up lots of ammunition at 8:40 pm, $280018 \mathrm{pdr}$ shrapnel, 200 Lyddite $4.5 \mathrm{How}$, and 600,000 of .303 ball [s.a.a.] were on the road to the refilling point. The supply was kept in Circulation during the whole night, the Canadian Ammunition Park...kept us well filled up. $^{70}$

It is essential that ammunition be available in both defensive and offensive operations. In this particular instance, the ability of the Canadian guns to slow the German advance and

\footnotetext{
${ }^{68}$ War Diary, 1st Canadian Division, Administrative Branches of the Staff, 21 April to 31 April 1915, LAC, RG 9, III D3, vol. 4837, microfilm, reel T-1921, file 83.

${ }^{69}$ Lieut-Colonel C.E. Long, "Ammunition Supply During the Great War. With Special Reference to the $1^{\text {st }}$ Canadian Division" Canadian Defence Quarterly, p. 134.

${ }^{70}$ War Diary, 1st Canadian Divisional Ammunition Column, 22 April 1915, LAC, RG 9, III D3, vol. 4977, microfilm, reel T-10806, file 581.
} 
remain in action was directly related to its supply services. Although apparently obvious, the idea that "the power of artillery is more truly judged by the number of shell that it is able to fire than by the number of its guns," is often overlooked. ${ }^{71}$

On 22 April 1915, the motor lorries of the $1^{\text {st }}$ Canadian Divisional Supply Column (D.S.C.) loaded routinely at Vlamertinghe station. They then brought their supplies to the refilling point on the road near the town of Breilen. Because of the German attack, early on the morning of 23 April 1915, the convoy of lorries was moved a mile away to a position on the Poperinghe-Steenvoorde road, and on 24 April, the supply railhead was moved to Godewaersvelde. The refilling point was also moved: its new location was a position on the Poperinghe-Elverdinghe road. Lieutenant W.A. Simson of the $1^{\text {st }}$ Canadian Divisional Train controlled supply arrangements forward of the refilling point, and he helped to ensure that no major break in supply arrangements occurred. Transport units along with their supply officers and other ranks worked hard to maintain the deliveries of rations, water and mail to their units despite changes of position because of the ongoing battle. Lieutenant R.H. Webb of No. 1 Company of the Canadian Divisional Train was assigned with providing supplies for the field artillery. He was awarded the Military Cross for his continual efforts over the course of ten days in the salient where he continued to supply the field artillery in addition to transporting back wounded men to dressing stations in St. Jean, Ypres, Brielen and Potjze. ${ }^{72}$

Even though parts of the supply chain were functioning quite well, soldiers in the

\footnotetext{
${ }^{71}$ H. De Pree quoted in Ian M. Brown, British Logistics on the Western Front, p. 34.

${ }^{72}$ A.F. Duguid, Official History of The Canadian Forces in the Great War 1914-1919 vol. 1, p. 419.
} 
midst of the fighting still went without sustenance. The $15^{\text {th }}$ Battalion, for example, had great difficulties supplying rations and water to the front lines on 23 April $1915 .{ }^{73}$ By 24 April 1915, the Canadians had endured three days of relentless pounding from German artillery. Many of their Ross rifles had malfunctioned, and they had been exposed to chlorine gas; and to compound the difficulties, soldiers had gone without food and water. ${ }^{74}$ The chlorine gas had another effect: it was later learned that "food exposed to the gas was said to have become quickly tainted and unfit for consumption, causing violent vomiting. Many rats are reported to have died in the dugouts.",75

While the logistical units such as the DAC and Divisional Train had still managed to perform their duties, it is unclear if the carrying parties that formed the last step in the logistical chain were maintained. These parties, in many cases, were disrupted by the intensity of the fighting. ${ }^{76}$ However, according to Matthews, on the night of April 22/23rd, his company's rations were brought up by Company Quarter Master Sergeant (C.Q.M.S.) McDonnell, much to everyone's relief. ${ }^{77}$ Private Hardman of the $16^{\text {th }}$ Canadian battalion recounted that many of his companions had been without food or water after their counterattack during the evening of 22 April. Moreover, the men were without means to keep warm because they had discarded their greatcoats and packs during the fighting. ${ }^{78}$ Another soldier stated "my kit was blown clear off my back in

\footnotetext{
${ }^{73}$ War Diary, 15th Canadian Infantry Battalion, 23 April 1915, LAC RG 9, III D3 , vol. 4924, microfilm, reel T-10718, file 390.

${ }^{74}$ Tim Cook, No Place To Run: The Canadian Corps and Gas Warfare in the First World War, p. 26.

${ }^{75}$ Colonel H.N. Thompson to $1^{\text {st }}$ Cdn Division, 6 January 1916, LAC, RG 9, III C9, vol. 4530, file 7.

${ }^{76}$ for a description of the fighting's intensity see Tim Cook, No Place to Run, pp. 24-27.

${ }^{77}$ Col. H.H Matthews, “An Account of the Second Battle of Ypres, April, 1915”, pp. 37-38.

${ }^{78}$ Daniel Dancocks, Welcome to Flanders Fields, p. 132.
} 
which I lost my razor, comb, underwear, socks, towel and soap." ${ }^{39}$ The friction caused by battle often put pressure on logistical services as lost equipment had to be replaced. In these cases, the loss of equipment and rations was more attributable to enemy action than any resupply failing. Logistics from rear areas to the guns was maintained, but there were supply and ammunition difficulties between battalions and their companies during the battle.

The attack had complicated other logistical issues. The roads leading into and out of the salient, passed through Ypres, which was heavily shelled. Local townspeople, horses and transport of all kinds including wagons, trucks, motorcycles, bicycles, even baby carriages clogged the roads. Travelling on the same road with this steady stream of fleeing refugees, but in the opposite direction, were infantry reinforcements, artillery and supplies of food and ammunition. ${ }^{80}$ Unknown to many of those passing through the area, the engineers had rigged the bridges for demolition in case the German attack penetrated further into Canadian held territory. ${ }^{81}$ Traffic congestion hampered resupply efforts, and rendered the work of the $1^{\text {st }}$ Division's supply services much more difficult.

During the first three days of the battle, the Canadians made a tenacious and determined defence. Throughout the battle, 40,122 artillery shells were fired along with approximately 7,000,000 rounds of s.a.a. in order to blunt the German assault. ${ }^{82}$ As a

\footnotetext{
${ }^{79}$ Albert Roscoe to Caleb Bateman, 13 May 1915, in J.L. Granatstein and Norman Hillmer, (eds.), Battlelines: Eyewitness Accounts From Canada's Military History (Toronto: 2004), p. 120.

${ }^{80}$ Daniel Dancocks, Welcome to Flanders Fields, p. 136.

${ }^{81}$ A.J. Kerry and W.A. McDill, History of the Corps of Royal Canadian Engineers vol.1, p. 90.

${ }^{82}$ War Diary, 1st Canadian Division, Administrative Branches of the Staff, Appendix 8, 21 April to 31 April 1915, LAC, RG 9, III D3, vol. 4837, microfilm, reel T-1921, file 83, p. 34. Gun Ammunition Expended: 18 pdr. Shrapnel: 28,870 rounds. 18 pdr H.E.: 4,284 rounds. Howitzer 4.5" Lyddite: 5613
} 
result, Ypres still remained in allied hands, but the cost of the battle was high. The $1^{\text {st }}$ Canadian Division's stay in the Ypres Salient from 15 April to 3 May resulted in enormous casualties: 208 officers, 5828 other ranks. Furthermore, the P.P.C.L.I., which had been a part of the $27^{\text {th }}$ British Division and had been deployed in the salient from 10 April to 21 May, suffered 678 casualties. ${ }^{83}$

The experiences of the first couple of months had revealed to the Canadians that logistical changes had to occur in many areas. While the logistical system worked well behind the trench system, closer to the front the problem of supplying s.a.a and grenades for infantry units during the battle remained an issue. In response to these difficulties, the $1^{\text {st }}$ Division formed a Divisional Small Arms and Bomb Supply Detachment with personnel drawn from battalion bombing officers and bombers. ${ }^{84}$ Another constant problem for all formations during this time was the need for unskilled labour to support engineering projects. Despite the employment of extemporized labour and entrenching battalions, usually from the infantry, in addition to civilian and refugee labour, the needs of the armies and divisions were still not being met. Formations were compelled to use their own resources of manpower, including large numbers of infantry to supplement their requirements.

It had been realized that the use of infantry as unskilled labour often deprived them of rest or training and was uneconomical, because there was considerable turnover

rounds. Howitzer 4.5" Shrapnel: 1,355 rounds. Small Arms Ammunition expended: 7,000,000 rounds.

${ }^{83}$ G.W.L. Nicholson, Canadian Expeditionary Force, p. 92.

${ }^{84}$ Lieut-Colonel C.E. Long, "Ammunition Supply During the Great War. With Special Reference to the $1^{\text {st }}$ Canadian Division" Canadian Defence Quarterly, p. 134. 
as infantry work parties were varied from day to day. ${ }^{85}$ Construction projects and other work in the battle area was often inefficient: in theory, all work in the forward area was determined at the divisional level, but in practice the brigade commander had authority. This resulted in a "lack of job-continuity and an immense waste of labour and material." The shortage of labour and the utilization of infantry as temporary workers did not make for an efficient system, and sapped the infantry of their ability to be optimally effective as fighting men.

One of the suggested temporary solutions for this labour shortage was to tap into a large supply of personnel available in units designed to meet the requirements of mobile warfare, and whose establishments were deemed unnecessarily big for the conditions of trench warfare. The following units were to be considered for providing manpower for engineering and other projects:

With G.H.Q.:

With Armies and Corps:

With Divisions:
G.H.Q. Ammunition Parks

Army Artillery Ammunition Parks Sub-Parks

Divisional Supply Columns Tractor Drawn Heavy Artillery Heavy Artillery on Railway mountings.

Brigade Ammunition Columns Divisional Ammunition Columns

Field Ambulances

It was up to the discretion of commanders, given local and tactical conditions, whether or

${ }^{85}$ Major General R. Butler to First Army et al., 28 February 16, LAC, RG 9, III C1, vol 3879, folder 14, file 22, "Organization of Labour."

${ }^{86}$ Kerry and McDill, The History of the Corps of Royal Canadian Engineers Volume 1, p. 101. 
not personnel from the above units could be spared ${ }^{87}$ It is unclear how many men were obtained by this initiative, but it remained a temporary solution to an ongoing manpower problem.

The $1^{\text {st }}$ Canadian Division was soon to form part of a Canadian Corps with the arrival of the $2^{\text {nd }}$ Canadian Division in September 1915, and would benefit from British support in addressing the labour problem. General Headquarters (GHQ) of the BEF was aware of the labour shortage in all formations, even along its own lines of communication. Because road work, for instance, required large numbers of labourers, reports from divisional commanders emphasized the need to reduce the wear and tear on roads by substituting lorry and tractor traffic with horse transport whenever possible. While this was done, Royal Engineer (RE) Labour Battalions were employed on road work and the construction of trench defences. ${ }^{88}$ However, labour requirements were still not being met.

Lieutenant-General E.A.H. Alderson, General Officer Commanding of the Canadian Corps, tried to adhere to the guidelines laid out by GHQ, provided that the units being drawn from were up to war establishment. ${ }^{89}$ The Canadian Corps also dealt with labour shortages by employing unskilled civilian labour to unload road metal and engineering stores from barges and at railway stations. Civilian labour made their own messing arrangements, and as a result could be called upon to work at irregular hours.

\footnotetext{
${ }^{87}$ Major General R. Butler to First Army et al., 28 February 1916, LAC, RG 9, III C1, vol. 3879, folder 14, file 22, "Organization of Labour."

${ }^{88}$ Ibid.

${ }^{89}$ Ibid, Lieutenant-General E.A.H. Alderson to $2^{\text {nd }}$ Army, 13 March 1916.
} 
When engineering stores arrived by train to the railhead, it was necessary to unload them and clear the railway yard in short order and civilian labour was able to aid this process considerably when no other workers were available. ${ }^{90}$ The importance of having adequate personnel to undertake the task of maintaining the logistical infrastructure of the Corps was realized at this time, but the problem could not be entirely rectified. Stripping manpower from other units was merely a stop-gap solution to a continuing problem. Commanders realized that maintaining their defensive positions and logistical communications, while at the same time conserving the effectiveness of their fighting arms, would be a difficult juggling act.

With intense pressure on roadways, increasing numbers of labourers were required to repair roads leading to the front lines. It was found early in the winter of 191415 that light railways and tramways could alleviate some of that pressure, and save much needed manpower. Lorry traffic on the roads could be reduced if light railways and tramways were used to take up some of the supply burden. This would also alleviate the need for the constant commitment of labour for road repair. As the forward area trench systems became larger and more complex, and as hostile artillery rendered forward areas into nearly impassable wastes of mud, supply echelons were forced to move further back from the fighting units they served as gaps between roadhead and the frontline trenches widened. This resulted in supply and ammunition carrying-parties becoming increasingly onerous exercises for units in the line. To make matters worse, in winter conditions,

\footnotetext{
${ }^{90}$ Ibid., Captain [?] for C.E. Canadian Corps to Canadian Corps, 10 March 1916; Chinese labour would also be used in the war see "Labour Companies ( $74^{\text {th }}$ Chinese, Report On)," 30 December 1917, LAC, RG 9, III Cl, vol. 3879, folder 14, file 21 .
} 
labour was often more than doubled because of the bad weather and thick mud. Forward area defences were being arranged in greater depth, and even in the best of times needed other means of supply to lessen the strain on the carrying parties of the fighting units. Logistical issues such as this one had a direct impact on the fighting efficiency of the infantry: if increasing numbers of soldiers were employed in carrying and labour duties, fatigued soldiers would have little time to hone their martial skills.

Because of these difficulties, during the winter of 1914-15, front-line companies and brigades began experimenting with tramway systems to ease supply problems. The majority of these first tramway lines were short spurs that ran from advanced supply dumps to guns or to support trenches, and were usually constructed out of any available materials: at least one division in the Ypres sector made its line with wooden rails. Vulnerable parts on the rails were 'armoured' with metal sheets cut from biscuit tins. Other divisions that were more fortunate or had more influential connections, scrounged quantities of light $9 \mathrm{lb} / \mathrm{yd}$ or $16 \mathrm{lb} / \mathrm{yd}$ rail, probing French sources for second-hand Decauville material. ${ }^{91}$ Simple four-wheeled push-trolleys were constructed by divisional engineers that used manpower or mules to pull trucks. A few innovators even made crude petrol electric tractors to pull tramway trucks. ${ }^{92}$

Early tramways proved to be very effective for transporting ammunition and stores forward. Divisions and even corps extended tramlines during the summer of 1915. These efforts met with some success, but were hindered by the expansion of the BEF, and

\footnotetext{
${ }^{91}$ The French firm Decauville Ainé had specialized in the manufacture of light railway materials.

${ }^{92}$ W.J.K. Davies, Light Railways of the First World War: a History of tactical rail Communications on the British Fronts, 1914-1918. (Newton Abbot: 1967) p. 24.
} 
the lack of continuity between incoming and outgoing units. Unfortunately, lines laid by one division were often abandoned or relaid by its replacement. The Canadian troops were among the few Corps who managed to develop extensive tramway systems in their area. A few other formations, particularly the Indian Corps holding the sector north of La Bassee Canal and, later, the XVII Corps, were also notable for their use of tramways. The realization that these tramways would help ease supply difficulties was eventually noticed by higher authorities at $\mathrm{GHQ} .{ }^{93}$

The Canadian Corps was a leader in the use of tramways in the forward area. The labour requirements for man-packing supplies continued to be large, and tramways helped to reduce the distances travelled by carrying parties. Canadian Engineers used wood-rail systems comprised of two-inch by three-inch runners on one-inch plank sleepers. Their usefulness was soon evident, and the demand for the extension of tramways increased. Tramway lines moved backward from the forward area to supplement horse transport that was normally used forward of the MT roadhead. Because the lorry tires of the day damaged the roads of the rear areas, huge road gangs were required to repair them. Tramways helped to significantly alleviate these problems and, because of their utility, feeder lines grew out from broad-gauge railheads so that tramways could begin their work in the Corps area at the soonest possible point in the supply chain. ${ }^{94}$

When possible, tramway lines were standardized using 60-centimetre (23.5 -inch) gauge along with 16 pound rail. All the lines that were in use prior to the summer of 1916

\footnotetext{
${ }^{93}$ W.J.K. Davies, Light Railwoys of the First World War, p. 25.

${ }^{94}$ Kerry and McDill, The History of the Corps of Royal Canadian Engineers Volume 1, p. 106.
} 
were tramways as opposed to light railways, which did not start to develop until May of 1916. Attesting to their growing importance, a Canadian Corps Light-Railway Officer (CLRO) was appointed in mid April of $1916 .{ }^{95}$ The CLRO would later act as a liaison between the Canadian Corps and the Army Assistant Director of Light Railways (ADLR). The CLRO was essentially responsible for the development of light railways in accordance with the requirements of the Canadian Corps. As the use of light railways and tramways in the Corps increased, however, they were divided into army light railways that utilized steam powered tractors in the rear areas and Canadian Corps tramways that used petrol/electric tractors or pack animals to operate in the forward areas. All proposals for the construction of new light railway lines in the Corps area were considered by the CLRO, investigated by him and then submitted to the ADLR for sanctioning before the work was undertaken. The CLRO in the Canadian Corps also held the position of Field Engineer in charge of tramways and was responsible to the Chief Engineer, Canadian Corps. ${ }^{96}$ The Canadian Corps was one of the few BEF formations that, early on, realized the importance of tramways and light railways, and the Corps had made them part of their emerging combined logistic scheme. ${ }^{97}$ This is due in part to the permanent structure and homogeneity of the Corps, and the willingness on behalf of the Canadians to innovate. The presence of many soldiers from the various arms and services in the Corps who had experience with railway work was also a factor.

The Canadian Corps' proficiency in this area would lead them to establish

\footnotetext{
${ }^{95}$ Ibid.

${ }^{96}$ Various, Overseas Military Forces of Canada, pp. 218-219.

${ }^{97}$ Colonel A.M. Henniker, Transportation on the Western Front, 1914-1918, pp.154-155.
} 
specialized units that devoted their time to the construction, maintenance and operation of tramways. What would be called, in 1918 , the $2^{\text {nd }}$ Tramway Company Canadian Engineers, had existed, without an authorized establishment, since 20 May 1916 when the Composite Pioneer Company was formed at Ypres. The original personnel, numbering some two hundred and twenty-five, were drawn from the $1^{\text {st }}, 2^{\text {nd }}$ and $3^{\text {rd }}$ Pioneer Battalions with Major R.P. Rogers of the $1^{\text {st }}$ Tunnelling Company Canadian Engineers appointed the officer commanding. This formation took over and operated 12 miles of track in the Poperinge/Kruistraate area near Ypres. ${ }^{98}$ The line, which had been constructed by the Canadians during their stay in the Ypres salient, was called a 'heavy tramline' and ran from Poperinghe to Vlamertinge to Kruistraat. Any wires passing across the tram line were to be raised 12 feet above it or buried under the track and no vehicles were to cross the track except for at the regular road crossings. ${ }^{99}$ The motive power of the trams at this time was supplied by two 20 Horse Power tractors. In July 1916, the Canadian Corps moved to the Somme area, and the company took over tramlines from Bray Road in Albert to Pozieres, and supply dumps in the Corps' area. In addition to the two 20 H.P. tractors, two steam engines were operated by the company in that area. Mules were also used and it was in this area that the company first evacuated wounded by light railway. ${ }^{100}$

The usefulness of tramways had been recognized in supporting defensive lines,

\footnotetext{
98."Historical Record $2^{\text {nd }}$ Cdn Tramways Company. C.E.”, 20 May 16 to 28 September 18, LAC, RG 9, III C5, vol. 4446, folder 2, file 10.

${ }^{99}$ Major [?] for C.E. Canadian Corps to Canadian Corps 'Q', 11 July 1916, LAC, RG 9, III C1, vol. 3890, folder 46, file 2, "Heavy Tramline, Poperinghe-Vlamertinghe, Kruistraat. July 1916."

${ }^{100 \text { " } H i s t o r i c a l ~ R e c o r d ~} 2^{\text {nd }}$ Cdn Tramways Company. C.E.", 20 May 16 to 28 September 18, LAC, RG 9, III C5, vol. 4446, folder 2, file 10.
} 
but not until after the battle of the Somme was underway, in the summer of 1916 , was it understood that they could support a large offensive. The official policy of the British was to concentrate efforts on pushing standard gauge railways forward far enough so that horse transport could take over directly in order to save lorry petrol. Yet mechanical transport was still used to a large extent. Tramways, meanwhile, were only adopted when absolutely necessary. However, an existing French light railway line, which ran approximately 6 miles from Acheux to Albert, was used for dumping ammunition and supplies, along with a $60 \mathrm{~cm}$ gauge system that had been built by the outgoing French divisions. It was considered at this time to be wasteful to undertake the task of providing an extensive tramway network because the tramways would be left behind in a new war of movement. This war of movement never arose because the German defences of deep dugouts, barbed wire and machine guns could not be pierced, and the British continued to rely on MT and HT forward of railhead. However, the poor road conditions that resulted from this traffic led to "the gravest difficulties in supplying the troops, and hindered, if it did not actually prevent, the further advance of the allies."101

Initially planned as a cooperative attack by French and British forces, the Somme offensive was now undertaken to relieve pressure on the armies at Verdun. The British hoped the weight of materiel, including thousands of tons of high explosives and shrapnel, would destroy barbed wire entanglements and exterminate German troops. After 1,738,000 British shells had been fired, the British attacked on 1 July 1916 with fourteen infantry divisions. The Germans, who had been well sheltered in deep dugouts,

\footnotetext{
${ }^{101}$ James E. Edmonds, Military Operations France and Belgium, 1916 (London: 1932), p. 275.
} 
scrambled to set up machine guns, and opened fire. In the first few hours of the attack, the BEF suffered 57,470 casualties. The Somme, which epitomized the fury of industrial war, raged for another four months, with the Canadians entering the charnel house in September. ${ }^{102}$

Aside from the horrors suffered by the infantry, supply issues were a fundamental problem for the BEF during the Somme because logistics in the battle area had become extremely difficult. Early in the Somme offensive, there was a shortfall of ammunition for heavy artillery, but this deficit was a result of tactical resupply failings caused by bad weather and deteriorating road conditions rather than a lack of ammunition in France. ${ }^{103}$ By the end of 1915, the munitions output of factories in Britain, the United States, and Canada had allowed the BEF's commanders to increase their ammunition expenditures, but this put a strain on the BEF's lines of communication that had been designed to meet the lower ammunition demands of the $1914-1915$ period. The BEF's ammunition problems during the Somme battle in 1916 were caused principally by enemy efforts to interdict resupply efforts in the battle area. Although some issues of ammunition quality still remained, after August 1916 the quantity of ammunition supply from Britain was assured. The real problem in supplying the artillery during the battle was on the tactical level: the British had not employed light railways to supply heavy shells to the artillery until the battle was well under way. They relied instead on horse transport to convey

\footnotetext{
${ }^{102}$ Tim Travers, "July 1, 1916: The Reason Why," in Robert Cowley ed., The Great War. Perspectives on the First World War (New York: 2003) p. 324; Tim Cook, No Place to Run: The Canadian Corps and Gas Warfare in the First World War, p. 76; J.L. Granatstein and Desmond Morton, Canada and the Two World Wars, pp. 62-63.

${ }^{103}$ Ian M. Brown, British Logistics on the Western Front, p. 123.
} 
ammunition to battery positions, and this method was not sufficient to keep the guns adequately supplied, which were essential to allowing the infantry to advance in trench warfare. ${ }^{104}$

Ammunition supply problems caused the pace of attack to slow down because not enough artillery ammunition was brought to the guns, which was essential in supporting attacking infantry. Despite the reinforcements provided by the new British Reserve Army and the assistance of units from the Third Army, the rate of advance fell after mid-July. It became apparent, by late August, that all hope of a breakthrough had dissipated. The Somme had become a battle of attrition. ${ }^{105}$

Before the Canadians entered the Somme area on 30 August 1916, they had to move from Ypres, which entailed a transfer of supplies and equipment to incoming units. A move of this nature required enormous planning and preparation. Guidelines for carrying out moves and reliefs were formally laid down by $\mathrm{Q}$ staff to ensure that Canadians travelled to new fronts fully supplied and equipped. These instructions also aimed to certify that certain trench stores did not leave the Second Army's area along with the Canadians. The Divisional Artillery was to march with all "echelons full" of ammunition. Any excess ammunition was to be handed over to the incoming divisional artillery. ${ }^{106}$

Receipts were required for the transfer of camp equipment such as tents, tent

\footnotetext{
${ }^{104}$ Ian M. Brown, British Logistics on the Western Front, p. 124.

${ }^{105}$ W.J.K. Davies, Light Railways of the First World War, p. 34.

106"Instructions for Move", 15 August 1916, LAC, RG 9, III C9, vol. 4530, file 13, "Moves and Reliefs. DAQMG Branch Instructions for." Hereafter Instructions for Move.
} 
bottoms, and lanterns to incoming troops. ${ }^{107}$ More paper work was required to furnish incoming troops with information regarding the location, type and amount of rations and water receptacles stored at strong points, supporting points and in the front line. It was expected that billets, camps, huts, dug-outs and horse lines were to be handed over in good order as well. Unserviceable stores were to be given over to the Divisional Salvage Company and any surplus ordnance stores or equipment were to be returned to ordnance stores. There was also a whole litany of equipment that was not to be removed from the Second Army area, including a range of boots (lumbermans and gum), clothing for night patrols, disinfectors, hot food containers, latrine buckets, soyer stoves, washing tubs and basins and so on. These stores were to be included on up-to-date camp inventories, which were sent on to the office of the DAQMG so that handovers could be smooth. ${ }^{108}$ As front line soldiers grumbled about the weary march south, staff officers at $Q$ branch suffered under a weight of paperwork.

For the Canadians on the Somme, the battles of Courcelette from 15 to 22 September, Thiepval Ridge from 26 to 29 September, Le Transloy Ridges from 1 to 18 October, Regina Trench during the 1 October to 11 November period, and Desire Trench from 13 to 18 November were engagements that enabled them to use new technology from a tactical standpoint, such as tanks. These battles also forced the Canadians to implement new logistical solutions to the challenge of attritional warfare. Here, on the Somme, the Canadian logistic system would be put to the test as it supported its troops in

\footnotetext{
${ }^{107}$ The handing over of trench stores also required a receipt from newcomers, and a list of the stores being handed over had to be provided on form AFW 3405.

${ }^{108}$ Instructions for Move.
} 
a battle that required a continuous supply of materiel to fight. ${ }^{109}$

One of the logistical services that would allow ammunition and supplies to flow into the battle area was the Corps' mechanical transport. As far as MT on the Somme was concerned, the Canadian Corps had adopted the practice of 'continuous running', which involved the supply columns working twenty-four hours a day. This entailed detailing two drivers for each lorry: one for operating the vehicle during daylight hours and the other for nighttime transport duties. ${ }^{110}$ In the daylight, the assistant driver and a loader would be on the vehicle, and for more difficult driving during the night, the first driver stepped in to operate the vehicle. The lorries were serviced by the workshop staff members during brief periods when they were stopped. ${ }^{111}$

With the advance in technology that occurred during the First World War came an overabundance of equipment for the average infantryman to carry. Infanteers during the Somme battles went into offensive operations with the least amount of equipment, but their burden was still substantial. Carrying 220 rounds of ammunition, four bombs, a pick or a shovel, rations, a greatcoat in case of cold and a waterproof sheet for wet conditions, sandbags, Very lights or signalling equipment, a respirator and a rifle, a heavily laden soldier found it difficult to manoeuvre. ${ }^{112}$ With battlefield experience, it was learned that the storage of some of the infantryman's equipment would allow him to be more effective in the assault because he would be able to advance more quickly. A lessening of his

\footnotetext{
${ }^{109}$ Bill Rawling, Surviving Trench Warfare, p. 71.

${ }^{110}$ J.L. Granatstein, Canada's Army. Waging War and Keeping the Peace (Toronto: 2002), p. 107.

${ }^{111}$ Arnold Warren, Wait for the Waggon, p. 104.

${ }^{112}$ Bill Rawling, Surviving Trench Warfare, pp. 70-71.
} 
burden would also prevent exhaustion and other health problems that would render him unfit for duty.

According to medical opinion at the time, a $68 \mathrm{Ibs}$. load was too much for a soldier to carry. It was suggested that during an advance, surplus articles that should not be carried forward, such as fur coats, extra shirts, drawers, socks, gloves, woollen vests and surplus iron rations, could be stored by the division. ${ }^{113} \mathrm{~A}$ study carried out by Lieutenant-Colonel Beveridge stated that the weight that an infantryman was called upon to carry was about $80 \mathrm{lbs}$. The soldier's burden was expected to increase by $20 \mathrm{lbs}$ if his overcoat became wet and another $14 \mathrm{lbs}$ if mud was on his equipment and trousers. It was, therefore, very easy for a soldier to be carrying in excess of $114 \mathrm{lbs}$, and such a burden would reduce an advance to a crawl of wheezing infantrymen: "engorgement of the base of the lungs, emphysema and increased cardiac and hepatic dulness...renal congestion, and impairment of renal function..." ${ }^{114}$ Lieutenant-General Julian Byng, commander of the Canadian Corps, suggested that storehouses be constructed at Bailleul, Hazebrouck, Lillers, St. Pol, Doullens, and Corbie for storing officers' kit and other property of units. ${ }^{115}$ Such measures, although addressing several issues, including medical and even tactical ones, show how pervasive issues of logistics were and how they affected the fighting abilities of a military formation. In the case of the average infantryman, mobility and fighting ability was enhanced when the weight that he carried was lessened.

\footnotetext{
${ }^{113}$ Lieut-General R.C. Maxwell, Q.M.G. to First Army, 27 February 1917, LAC, RG 9, III Cl, vol. 3894, folder 59, file 25, "Weight Carried By Soldier".

${ }^{114}$ Ibid, Lieut-Colonel Beveridge "Memorandum On the Weight Carried In Relation To The Health Of The Soldier", 26 January 1917.

${ }^{115}$ Ibid, Lieut-General J. Byng to First Army "Q", 12 March 1917.
} 
Yet, the infanteer needed this kit in order to hold ground during an attack. If the kit crucial to the first wave's consolidation efforts was given to the second and third waves to carry, and the infantry in those follow-on waves were killed or wounded by a German counter-barrage, that equipment would be lost. ${ }^{116} \mathrm{~A}$ failure to successfully consolidate an objective made a position untenable, and the Canadians risked being annihilated by a German counter-attack. This is yet another case where logistical considerations were contemplated in order to improve the efficiency of the fighting arms in not only the Canadian Corps, but in the BEF Army formations as well.

The Canadian war experience featured an evolution not only at the sharp end of battle, but in terms of logistics as well. Over the course of the war, different methods were used to transport rations, for example, via carrying parties, from field kitchens to the frontline soldier. After much trial and error, the delivery of supplies was made more efficient by enterprising officers and men. The introduction of the Thermos Pack enabled Canadians to deliver hot soup to Canadian soldiers on the Somme in 1916. An army truly fights on its stomach, and it is essential that the fighting man receive his rations in order to maintain both his physique and his morale. If attention is not paid to such considerations, armies would cease to function as effective fighting formations. The failure to deliver the daily rations or rum issue was always a sure way to put the men in bad spirits. One of the Canadian Infantry Brigades on the Somme in 1916 issued instructions that rum was not to be issued to the men. Instead, they were to rely on pea soup and lime juice. The men were not pleased. News soon spread to their neighbours,

\footnotetext{
${ }^{116}$ Dr. Tim Cook to author.
} 
who nicknamed the men of the $11^{\text {th }}$ Canadian Infantry Brigade the "limejuicers." After news of the discontentment in the trenches reached the upper echelon of command, the decision not to issue rum was eventually reversed. ${ }^{117}$

Rum had traditionally been issued to British soldiers in times of war, and it was equally customary for soldiers to complain if they did not receive their ration in the trenches. When Canadian troops fought under British command during the South African War, they were issued a gill of rum (two ounces) three times a week. The tradition continued on the Western Front. In France, the issuing of rum was usually supervised by officers and was given to men at stand-to at dawn and stand-down at dusk. The likelihood of attack was highest at these times, and required all personnel of the forward unit to be in the firing line. If there was no imminent threat, sergeants poured out two ounces of 186 proof Special Red Demerara (S.R.D.) Jamaican rum to each man. It was rare for any soldier to refuse the rum issue. ${ }^{118}$ Rum was one of the most popular comforts offered to soldiers. It acted as a reward, a means to maintain combat motivation, and a medicine. ${ }^{119}$ Rum's importance to the morale of the men is a testament to the importance of having a sound logistic system in place. Without the proper nutritional and mental sustenance, formations would cease to function effectively as fighting units.

Despite the terrible discomfort experienced in the front lines during the last months of the 1916 Somme battles, the experiments that had been conducted to offset the

\footnotetext{
${ }^{117}$ F.R. Phelan, "The Army and Its Stomach: The Thermos Pack", Canadian Defence Quarterly vol. VII, no.3 (April 1930), p. 349.

${ }^{118}$ Tim Cook, "“'More a medicine than a beverage"'Demon Rum' and the Canadian Trench Soldier of the First World War", Canadian Military History vol. 9, no. 1 (Winter 2000), p. 8.

${ }^{119}$ Ibid, p. 7.
} 
lack of rum in Victor Odlum's 11th Brigade led to improvements to the ration issuing system. Because rum was denied, the Brigade staff attempted to issue hot soup to the men in the line. At that time, the frontline was located approximately 4000 yards from the point where rations were dumped after they had been brought up in limbers from the transport lines in the city of Albert. The first attempt at transporting soup was a failure. Soup was cooked at the transport lines in the regular cookers, and the massive cylindrical stew pots were lifted out, placed in limbers and transported as far up the Albert-Bapaume road as was possible. At this point, the pots were hung from large poles and were each given to a carrying team of eight men. The men then attempted to carry the large pots into the line. Under the best of conditions, they arrived exhausted; under shellfire, most of the food was lost as men dove for cover. This method was attempted just once because not only had it tired the carrying parties to the point of exhaustion, but few of the large cooking pots were ever returned to the travelling kitchens. ${ }^{120}$

Despite this and other failures, further experiments were attempted in order to bring hot soup into the line. The most successful attempt involved an apparatus that was based on the thermos principle. The thermos pack was small enough to allow the carrier to arrive at his destination after a five hour trip from the transport lines without being overly fatigued, and it still kept the soup hot (if it had been poured into the apparatus just after boiling). Petrol cans had become the standard water carrying vessel during the war, and they served as the basis for the thermos pack. The thermos pack was relatively easy to construct, and was not overly bulky or heavy to carry. The pack was constructed, by the

\footnotetext{
${ }^{120}$ F.R. Phelan, "The Army and Its Stomach: The Thermos Pack", p. 350.
} 
battalion pioneers, from easily obtainable materials: petrol cans, tin for an outside casing, solder, felt or tar paper, old newspapers and strips of wood. A special harness was made from salvaged webbing, which allowed one man to carry two packs, one on his back and one on his chest. Each petrol tin or pack contained 16 rations of soup, enough for one man to carry rations for a whole platoon of approximately 30 men. After the carrying party returned to the transport lines after their trip to the front lines, the thermos packs had to be cleaned out with water so that they did not become sour. It was the quartermaster's responsibility that the special carrying parties were detailed to the line and he also ensured that all packs were cleaned when the party returned. Shortly after the pack's inception, a large supply of them were constructed, and they contributed to the comfort and welfare of the troops. The thermos pack was found to be a "useful device" for carrying hot soup or tea during the Vimy Ridge operation. ${ }^{121}$

The realization that the supply arrangements for the forward area had to be rendered more efficient was one of the most important lessons learned on the Somme. Like the thermos pack, the tumpline served to maximize the use of manpower in the delivery of supplies to the forward area. The Somme was the first instance where Canadian troops were involved in offensive operations of a large nature, and the poor conditions in the area exacerbated the problem of getting supplies to the troops of the line. Throughout the two-month tour, supplies had to be brought by pack animal or man over a distance of approximately 5000 yards under horrible conditions. Before the outbreak of the First World War, Frederick Ross Phelan was an avid hunter and

\footnotetext{
${ }^{121}$ F.R. Phelan, "The Thermos Pack", pp. 351-352.
} 
fisherman who had experienced the difficulties of transporting supplies and canoes overland in the back woods of Quebec where it was impossible to move continuously by water. The tumpline was used in order to overcome these transportation difficulties. At the Somme, Phelan made the suggestion that the tumpline, which had served him so well in Canada, could be adopted to solve the problem of forwarding supplies to troops of the $11^{\text {th }}$ Brigade. The tumpline was a simply designed accessory of oiled leather that enabled a man to transport heavy loads. The tumpline consisted of several parts. The first was a brow band, which was 21 " long by about 3 " wide in the central portion and tapered at the bottom end. Rivets were often added in order to strengthen the joint that attached the straps to the brow band. Phelan stated that tumplines made of canvas or web material were useless because they became unserviceable when wet and were difficult to untie, and they also chafed the head. Quality tumplines could be manufactured by saddlers or shoemakers from the battalion by using salvaged surcingles and reins. ${ }^{122}$

Because the spine is able to support heavy weights, the tumpline was designed so the weight of the load carried was transferred in a straight line down the spine. The load of boxes, sacks or other material would be piled high, tied together by wrapping both straps around each end of the load and fastening them together with a timber hitch, or half hitch in bow so that it could be undone quickly. When the load consisted of small articles, it was customary to roll them in a blanket and carry the bundle with the tumpline. With the two ends of the tumpline tied, the 3" wide brow band formed a loop that rested on the forehead with the load resting high on the back. The tumpliner walked bending

\footnotetext{
${ }^{122}$ F.R. Phelan, "Army Supplies in the Forward Area and the Tumpline System", pp. 32-34.
} 
forward slightly with his hands grasping the tumpline straps around the ears in order to both steady the load and distribute the weight to his shoulders. The loads carried by the tumpliners varied depending on what commodity was needed at the time. ${ }^{123}$

The $11^{\text {th }}$ Brigade's tumpline company made the forwarding of supplies, ammunition and other items more efficient throughout October and November of 1916. Every night for 45 consecutive days, the brigade tumpline company of some 85 men negotiated the 4000 to 5000 yards from the main to advanced dumps with the following as cargo: 1 to 2 boxes of small arms ammunition, 4 boxes of mills grenades, 3 boxes of stokes shells, 2 boxes of bully beef, 1 case of biscuits, 1 bale of Sandbags, 2 coils of barbed wire, a dozen shovels, and a dozen picks. The company, on one particular night, transported five complete Soyer stoves along with three 50-gallon iron tanks. This organization was efficient and remained unaltered for the balance of the war, and was soon adopted throughout the Canadian Corps.

Following the Somme, each battalion of the Brigade created another section of 1 $\mathrm{NCO}$ and 15 to 20 men for the purposes of transporting the unit's water and rations to the front along with ammunition and supplies in the event of an emergency or in offensive operations. The tumpline company was separated from their parent battalions and was under the control of the brigade staff captain. Meanwhile, the additional battalion sections remained under the control of the battalion bombing officer and were affixed to battalion headquarters. After it came to the attention of the general staff, units in the First Army

\footnotetext{
${ }^{123}$ F.R. Phelan, “Army Supplies in the Forward Area and the Tumpline System”, pp. 34-35.
} 
began to adopt the tumpline in the latter part of 1917 and early $1918 .^{124}$ The tumpline system, as devised by Phelan, was an efficient way to transport supplies to the forward area compared to other hand carrying methods. It is a testament to how the Canadians were constantly searching out ways to streamline their logistical system. With scant manpower resources available, the tumpline system made a significant impact on freeing even more soldiers from the daily chores of ration and carrying parties. While seemingly mundane, providing efficient carrying parties to the forward area would render the Canadian Corps more effective as a fighting force as it freed up infantry from strengthsapping fatigues.

It was also realized that the duties of the tumpliners could be employed while offensive operations were underway. If manpower was freed up to fight, through the efficient use of tumplines carrying supplies forward, the concentration of force that the infantry could bring to bear would be greater, and more importantly the infantry assault could maintain its forward momentum if it was being fed with supplies and ammunition. Tumpliners would also aid in the consolidation phase of the infantry assault as Canadians dug in to repulse German counter-attacks, a hallmark of the German defensive system throughout the war, and would aid with the evacuation of wounded.

The $11^{\text {th }}$ Canadian Infantry Brigade laid out their standard attack scheme prior to their operation against Regina Trench in October, and they included contingency plans for

\footnotetext{
${ }^{124}$ Ibid, pp. 35-36, 39; After Captain Archibald, who was stationed at the Canadian Corps $5^{\text {th }}$ Divisional School, gave a demonstration in the use of the tumpline, a colonel from First Army asked if 50 of the tumplines could be loaned to headquarters, XI Corps, to carry out trials. See Colonel [?] D.D.O.S. First Army, to Canadian Corps, 20 February 1917, LAC, RG 9, III C1. vol. 3894, folder 59, file 22, "Tump Packs".
} 
the use of tumplines and other logistical issues such as the maintenance of water supply, ammunition, transport, the evacuation of wounded and battlefield salvage. As laid out in the Standard Attack scheme, Phelan's duties included arranging the Pack Mule Train ${ }^{125}$ for carrying purposes and he would also provide instructions for the $11^{\text {th }}$ Tumpline Company during the battle. Phelan was also charged with arranging the transportation of water to the Advanced Brigade Dump, providing 50 blankets per battalion for the Regimental Aid posts and organizing special battlefield clearing parties that would consist of 30 other ranks under the control of one officer. It was unclear how many clearing parties there would be, but twenty-five stretchers would be allotted to every 100 men for collecting wounded and dead. The officer in charge of these clearing parties, Lieutenant Burde, would supervise all supply and ammunition dumps, he would be immediately responsible for carrying duties during the attack from the main brigade dump to the Advanced Brigade Dump and From the Advanced Brigade Dump to four battalion dumps in the Canadian Front line. He was would also be required to organize all guides for the carrying parties. Burde, along with the Battlefield Clearing Parties under his charge, were to clear the battlefield of wounded, dead and salvage. ${ }^{126}$

In laying out the preparations for the Regina Trench operation, the Pack Mule Company was to be used for the transportation of ammunition and water from the main

\footnotetext{
${ }^{125}$ The Pack Mule Train comprised of 1 officer, 4 N.C.Os 36 muleteers, 8 loaders and 36 pack animals, and if needed 8 additional mules and their drivers would be employed to use stone boats (a flat sledge or drag for transporting heavy articles).

126، $11^{\text {th }}$ Infantry Brigade Standard Attack Scheme", 11 October 1916, LAC, MG 30, E 54, F.R. Phelan Papers, file 1-15, "1916-1917 General, $11^{\text {th }}$ C.I.B. Operation Orders, Administrative Instructions, etc". Please note that some of the F.R. Phelan papers have yet to be formally organized and have, therefore, been identified on the file level. Hereafter $11^{\text {th }}$ Infantry Brigade Standard Attack Scheme.
} 
brigade dump to a point near the North Practice trenches, one kilometre behind the front, where they were to drop-off their cargo. The drivers and mules would also be required to push ammunition forward "as far as possible" during the attack, and strong bridges would be required across the trenches in case this was needed. Stone boats, flat sledges used to drag loads, were to be used while the operation was underway to transport loads from the main dump to the Albert-Bapaume Road, where they were to be transferred, by a loading party, onto limbers that would carry them 200 yards west of the Albert-Bapaume Road junction. From this point, the loaders would transfer the ammunition to the pack train. The instructions in the general attack scheme further stated that this process would only be undertaken if it was necessary to move ammunition forward quickly from the main dump, "but would not be resorted to...on account of the amount of handling necessary."127 Phelan stated later that the mule train, in all large operations, "did yeoman service and assisted materially in the success of the supply arrangements." 128

The attack scheme called for the tumpline company to advance ammunition as normal from the main brigade dump to the advanced dump, and during the action from that stockpile to any forward point necessary ${ }^{129}$ If the attack had been successful, captured ground would have to be consolidated by the infantry and the tumpliners were assigned the task of moving munitions forward to positions that would be accessible for the troops in these advanced positions. This was a key step in the consolidation process because the infantry would require s.a.a. and other armaments to fend off counter-

\footnotetext{
$12711^{\text {th }}$ Infantry Brigade Standard Attack Scheme, Appendix: Supply Arrangements.

${ }^{128}$ F.R. Phelan, "Army Supplies in the Forward Area and the Tumpline System", p. 41.

${ }^{129} 11^{\text {th }}$ Infantry Brigade Standard Attack Scheme, Appendix: Supply Arrangements.
} 
attacking German forces. This phase in the tumpline company's duties would take up the first few hours of the operation, and after it was completed, the tumpliners would assist the battlefield clearing parties with the removal of wounded. ${ }^{130}$

In addition to the essential service provided by carrying parties and specially detailed pack transport, engineering work figured heavily in the logistical support needed to sustain the advance at the battle of Courcellete during the Somme offensive. The Engineering services, by the time they arrived in the Somme area, had adopted the structure that they would retain until they were re-organized in May $1918 .^{131}$

The pioneers provided trained personnel for working parties and slightly eased the manpower problems experienced by the Canadians. The engineers lent their expertise to the three infantry brigades in the field. Just as carrying parties and pack transport pushed forward supplies to assist the infantry in the consolidation of enemy held territory, engineers would aid in the construction of the infrastructure needed by the infantry. During assaults, captured trenches had to be consolidated to fend off enemy counterattacks, which were part of the German defensive doctrine for much of the war. While the strongpoints lay outside the traditional realm of logistics, the act of fabricating these points of resistance by the engineers, and the transportation of material to aid in building them, was definitely a logistical endeavour. On 15 September 1916, the Sixth Field

\footnotetext{
${ }^{130}$ F.R. Phelan, "Army Supplies in the Forward Area and the Tumpline System", p. 41.

${ }^{131}$ Bill Rawling Technicians of Battle, p. 24.; On the Somme, each Canadian division contained: A Headquarters, for the Divisional Engineers that was comprised of 4 officers, 20 other ranks, and 15 horses. Three Field Companies that each had 6 officers, 210 other ranks, 73 horses, and transport that included pontoon equipment for 75 feet of medium bridge and a Pioneer Battalion made up of 30 officers, 1000 other ranks, and 54 horses. It was a total divisional force of 58 officers, 1,650 other ranks and 303 horses. See Colonel H.F.H. Hertzberg, "The Re-Organization of the Engineering Troops of a Canadian Division Great War 1914-18" Canadian Defence Quarterly vol.1 no. 4 (July 1924), p. 39.
} 
Company of Engineers was to construct two strong-points while attached to the $5^{\text {th }}$ Brigade. When the $22^{\text {nd }}$ and $25^{\text {th }}$ Battalions captured Courcelette, sections 1 and 3 of the $6^{\text {th }}$ Field Company moved forward to help consolidate the position. Where Canadians had only captured part of an enemy trench, blocks had to be put in place, strongpoints established and observation points constructed. The engineers were also given the task of digging by-passes at busy trench intersections to allow foot-traffic to flow, they sited new support trenches across no-man's land, remaking tracks, clearing water wells, reversing dugout trenches, preparing gun positions and running trench tramways forward into the new position. ${ }^{132}$ This was a comprehensive range of consolidation tasks that while sound in theory, because of its attention to tactical and logistical considerations, but was often more difficult in practise as engineers sustained casualties. It had become evident, during the battles of the Somme, that in order to hold newly won territory it had to be consolidated properly, and this process relied directly upon logistical considerations such as the extension of lines of communication via tramways to ensure supplies and ammunition reached the front along with carrying parties and pack transport to move ammunition forward to fend off counter-attack forces.

By the end of September, the advance had bogged down in the mud of an uncharacteristically damp fall, and the front finally stabilized at the end of November. The Somme battles had not achieved the breakthrough sought by Haig and this failure was exacerbated, in part, by the BEF's lack of experience in preparing logistically for

\footnotetext{
${ }^{132}$ Bill Rawling, Technicians of Battle, p. 24; Kerry and McDill, The History of the Corps of Royal Canadian Engineers Volume 1, p. 118.
} 
large-scale troop advances. The result of the battle was a strip of shell-torn ground thirty miles long and seven wide, which had been gained at a cost of some 600,000 casualties, 410,000 of whom were British. ${ }^{133}$

Not only were large ammunition stockpiles for artillery needed to allow gunners to support the forward movement of troops, but s.a.a., water and other supplies had to be provided to infantry who were required to take and hold objectives. The use of tramways and lorry transport in the Canadian Corps area were essential in order to provide the artillery with the shells necessary to help infantry move forward. A combined logistics approach supported the firepower requirements of the set-piece battle. The link between logistical preparation and the continuance of logistical support during an advance to battlefield success was not lost on the Canadians. The logistical preparations on the Somme foreshadowed the creation of complex works, such as the underground subway systems at Vimy. The logistical structure that was set in 1915 took the Canadians into the Somme, where they learned more lessons from bloody experience. These lessons were integrated into the combined logistics system and would help the Corps prepare for the monumental battles of 1917 .

\footnotetext{
${ }^{133}$ W.J.K. Davies, Light Railways of the First World War, p. 34.
} 


\section{Chapter Two}

\section{Supplying the Set-Piece Battle: Vimy and Passchendaele, 1917}

Logistics were a key element enabling the Corps to assault up the slopes of Vimy Ridge and survive the horrors of Passchendaele in 1917. The lessons and experience gained by the Canadian Corps during the Somme Offensive were put to good use in these two major battles. The successful set-piece battle at Vimy saw the continued evolution of the combined logistics system as new modes of supply and techniques were integrated into the Canadian Corps' repertoire.

One of the lessons learned during the Somme was that Divisional Pack Companies (DPCs) could be used effectively, as troops in the line received rations, water, munitions and other items after an advance had occurred. When it was impossible to use the battalion's first line transport, with its wagons and limbers, to move over shell torn ground, the DPC was to be used for forward supply. During the advance, infantry would require ammunition and other kit. Units made demands for the use of the DPC through their brigade headquarters. Indents articulating these requests were then sent to ' $Q$ ' branch at the divisional headquarters by $4 \mathrm{pm}$, in order to make arrangements for the following day. Guides then led pack detachments to advance points selected by the officer commanding of the Pack Company where carrying parties from the unit took over supplies. Transport officers and company quartermaster sergeants accompanied the carrying parties from the unit to coordinate the transition from the DPC. The Officer Commanding and other officers attached to the DPC were charged with finding mule tracks in the forward area and were also encouraged to find new ways of transporting 
different types of items. ${ }^{134}$ It is evident from the formation of the DPC and its importance in providing ammunition and other supplies to forward units that the Canadian Corps had made logistical considerations part of their offensive scheme. This forward movement of supplies and s.a.a. ensured fighting efficiency because units who had gone forward during the attack were able to fend off counter-attacks since the supply chain never ceased to function.

Prior to the Vimy attack, Arthur Currie visited Verdun in an effort to learn what he could from French offensive operations by studying the battlefield and interviewing French officers. He derived four basic principles that were to become integral to the Canadian Corps attack doctrine: that extensive preparations "led to success, that nothing should be neglected, that platoon tactics should be stressed, and that tactically important features should be the objectives of an attack." ${ }^{, 135}$ Logistics were an important part of these preparations. Although Currie was not overly impressed with the way the French handled their supply dumps and carrying parties, and thought that the Canadians already paid more attention to these type of logistical arrangements, he did take note of the importance that the French attached to road construction and the laying of narrow gauge railways. Currie observed that "supplies were carried up as close as possible to the front line by means of railways and further forward by men and donkeys." ${ }^{\prime 16}$ The French

\footnotetext{
${ }^{134}$ Major-General L.J. Lipsett to Canadian Corps Q, 19 May 1917, LAC, RG 9, III C1, vol. 3885, folder 32, file 4 ,"Administrative Reports of Operations. Vimy."

${ }^{135}$ Ian M. Brown, "Lieutenant-General Sir Arthur Currie and the Canadian Corps 1917-1918: The Evolution of a Style of Command and Attack", p. 19.

${ }^{136}$ Major-General A.W. Currie, "Notes on French Attacks, North-East of Verdun in October and December, 1916", 23 January 1917, LAC, RG 9 III C1, volume 3893, folder 56, file 14.
} 
believed that before an advance could take place, roads needed to be built and tracks layed because it was only through these logistical conduits that the forward movement of artillery could be facilitated. The success of future attacks depended on the artillery pieces getting onward because infantry could assault most effectively with artillery fire support. To these ends, the French built one small railway track in each divisional area, one road was made for each division and at least one communication trench was constructed for each regiment. ${ }^{137}$

Currie also confirmed that surprise could be achieved even if lengthy artillery preparations occurred prior to an assault. The laying down of false artillery barrages would force the Germans to reveal their own defensive fire patterns, which would aid counter-battery work. These barrages would also confuse the enemy as to when the real barrage would fall accompanied by the infantry attack. If the Germans were expecting another false barrage, they would react slowly when the real assault occurred. ${ }^{138}$ It must be noted that Currie initially gave the impression that many of the recommendations in his report were learned directly from the French, but this was not necessarily the case. Currie was not only learning from the French, but also confirming his own ideas and pushing concepts that already formed part of British operations. ${ }^{139}$ In the case of narrowgauge railways, efficient carrying parties and the use of pack transport during ongoing operations, the Canadians had already established themselves as leaders.

\footnotetext{
${ }^{137}$ Ibid.

${ }^{138}$ Ian M. Brown, "Lieutenant-General Sir Arthur Currie and the Canadian Corps 1917-1918: The Evolution of a Style of Command and Attack," p. 19.

${ }^{139}$ A.M.J. Hyatt, General Sir Arthur Currie: A Military Biography (Toronto: 1987), p. 63.
} 
The Corps also possessed a superior counter-battery establishment, which outclassed its German counterpart, but it needed to be supplied with a large quantity of shells. Efficient intelligence gathering techniques such as sound-ranging, keenly observed meteorological data, air photographs, unit patrol debriefs, information from prisoners, and reports on hostile enemy artillery battery positions gave the Counter Battery Service Office (CBSO) an accurate picture of the location of German artillery pieces. With this knowledge, Canadian and attached British batteries assigned to counterbattery tasks used high explosives, shrapnel and poison gas to eliminate hostile batteries, or at the very least, diminish their rate of fire. Successful counter-battery shoots would give advancing infantry more protection during the assault: if German artillery was silenced or forced to lessen their rate of fire, infantry could advance more quickly, and with fewer casualties. ${ }^{140}$ The artillery intensive programs responsible for false barrages, counter-battery work, engaging known strong points and long-range harassing fire was predicated on a vast logistical infrastructure that would have to be built up prior to the attack in order to provide guns with adequate ammunition to make these fire-plans possible.

After he returned from his visit to the Verdun battlefield, Currie gave a series of informative lectures outlining ideas that he had either gleaned or reaffirmed from his review of the Verdun battlefields, many of which found their way into the plan for the

\footnotetext{
${ }^{140}$ Tim Cook, No Place To Run: The Canadian Corps and Gas Warfare in the First World War, pp. 107-108; Dan Jenkins, "Winning Trench Warfare: Battlefield Intelligence in the Canadian Corps, 19141918", Ph.D. Thesis, Carleton University, 1999.
} 
assault on Vimy Ridge. ${ }^{141}$ Sir Julian Byng, as Corps Commander, listened to his protege and instituted many of his suggestions. The strategic purpose of the attack was to form a defensive flank for operations that would be undertaken by the BEF's Third Army to the south. The capture of the ridge would also drive the Germans from an excellent observation point that overlooked the valleys to the south, and in turn would allow the British to survey the low-lying terrain to the north and east, aid future operations and threaten German-held French industrial districts. ${ }^{142}$

The enormous scope of the preparations to support the battle at Vimy were necessary in order to fulfill the plan's firepower requirements. The immensity of the build-up was not lost on Victor Wheeler of the $50^{\text {th }}$ Battalion:

the war-scourged Souchez Valley was being saddled with all the military implements for bloodshed and human annihilation that the Allies could manufacture and deliver to this wracked area. Great pyramids of ammunition, shells of all sizes and calibres, high explosive fuses rose from the flatland...Enormous quantities of war material of every description were being dumped on every spot of land that was remotely safe from the Boche guns or Luftstreitkrafte bombs. The gunpowder obelisks looked like mountainous black slag-heaps of culm or coal dust standing silent guard over the near-by Houille Des Mines in the Bruay and Lens Areas. Scattered dumps of all kinds were scabs on the landscape. The Souchez Valley, embracing the whole Corps Area, was rapidly becoming a mammoth delayed-fuse arsenal. ${ }^{143}$

The combined logistics system in the Canadian Corps would become manifest at Vimy. It coincided with the emergence of the set-piece battle that featured the tight integration of infantry, with a massive artillery fire program that would provide a creeping barrage for advancing infantry, engage strong-points and enemy batteries; an

\footnotetext{
${ }^{141}$ G.W.L. Nicholson Canadian Expeditionary Force, p. 250.

${ }^{142}$ War Diary, "Report, Canadian Corps. Operations. Vimy", 31 May 1917, LAC, RG 9, III D 3, Volume 5058, microfilm, reel T-11120, file 968. Hereafter War Diary Report Vimy.

${ }^{143}$ Victor W. Wheeler, The 50 th Battalion in No Man's Land (Ottawa: reprint 2000), p. 79.
} 
effective counter-battery plan to locate and destroy German artillery; and an unprecedented allotment of machine guns for long-range, indirect harassing fire. Not only did the system have to provide the fighting arms with the ammunition required, as described by Wheeler, it needed to equip, feed, house, and protect the infantry prior to and during the attack.

The bombardment that preceded the attack commenced on 20 March. It targeted front and rear areas, and yet not all of the guns opened up in order to remain hidden from observers. On 2 April the intensive phase of the artillery bombardment began as thousands of shells were required to destroy German positions. One Canadian noted that shells were fired "over our heads like water from a hose, thousands and thousands a day." During the "week of suffering," as the German's named it, over a million rounds of heavy and field artillery ammunition were fired. Not only had the Canadians realized the importance of logistics for their own operations, but they realized their importance to the enemy. Part of the artillery fireplan targeted enemy roads and other routes of approach in order to slow German logistics operations. Enemy ration parties that had formerly negotiated communication trenches in fifteen minutes now took nearly six hours to bring food to the front through the shelling. When food did arrive, it was often cold and spoiled and many troops of the line had nothing to eat for several days at a time. This harassment of logistical lines was a "major cause of weakness in the defence."144 Later, during the attack, Captain Walter Moorhouse of the $4^{\text {th }}$ Canadian Mounted Rifles spoke to

\footnotetext{
${ }^{144}$ Unless noted references in this paragraph are from G.W.L. Nicholson, Canadian Expeditionary Force,p. 251
} 
one prisoner that "had hardly eaten for the past three days on account of our shelling holding up their ration transport."145

As part of their own logistical preparations, the Canadian Corps area was divided into four forward zones, one for each division. They were known, from right to left, as $\mathrm{x}$, $y, a$ and $b$ regardless of the division that was located in the area. ${ }^{146}$ Because of the scale of the operation, a great number of army and corps troops were accommodated in each of the four areas along with the personnel from the four divisions. It was necessary, in order to maintain the fighting efficiency of the Corps, to provide personnel with adequate accommodation. While not luxurious, billets and other structures were a far cry from sleeping in the open in cold weather. As of 12 March 1917, additional huts were required to provide further accommodation to the Corps' 100,000 troops, and a large number of tents and covers trench were provided for use at horse lines and other locations where billets did not exist. An additional staging camp that consisted of five hundred tents was being pitched in the Bois d'Olhain to provide shelter for one brigade when it moved into or out of the forward area. ${ }^{147}$ On 8 April 1917, Deward Barnes of the $19^{\text {th }}$ Battalion found himself taking up residence in a tent: "Easter Sunday, a grand day. We moved to huts and tents near Arras, which the Germans held. I stayed in a tent. The huts, etc. were shelled very often, that's why they had some tents as some of the huts had been destroyed. In a

\footnotetext{
${ }^{145}$ Pierre Berton, Marching As to War. Canada's Turbulent Years 1899-1953 (Canada: 2001), p. 179.

${ }^{146}$ The Corps sector also featured the Ruitz transfer area that could hold one brigade group. Thirdly, the Auchel rest area was large enough to contain one division.

147“Administrative Arrangements", 12 March 1917, LAC, RG 9, III C1, vol. 3885, folder 32, file 3, "Vimy. Operations April 1917", pp. 1-2. Hereafter Administrative Arrangements Vimy.
} 
shell hole outside, a horse was sitting up. It looked funny for he didn't seem dead."148 The majority of these billets were constructed by the engineers, attached labour and even tunnellers. These soldiers were an integral part of the combined logistics system. Not only were they required to construct accommodation before the assault on Vimy, they were also needed to fabricate bathhouses, laundries, disinfectors, latrines and incinerators in order to meet the sanitation needs of such a large population. Because of the cold weather, tinsmiths were gathered from the ranks of many different units in order to produce Quebec heaters complete with accompanying pipe and accessories. ${ }^{149}$

After arriving in the Vimy area, Will Bird and his companions were initially guided to an unfurnished cellar in Neuville St. Vaast, but through a bit of luck managed to take up residence in another basement complete with "bunks...a stove and extra blankets." ${ }^{150}$ In order to supervise such billeting arrangements, town majors and area commandants were appointed in locales where troops were out of the line. They were also required to ensure the billeting area met sanitation requirements. ${ }^{151}$ Earlier in the war, precautions against fires in billets were formulated: a fire picquet under an officer was assigned by each unit upon taking over its billeting position, and a tin of dry earth, sand or water was to be kept ready in case of a fire breaking out. If the fire spread, the town

\footnotetext{
${ }^{148}$ Bruce Cane, It Made You Think of Home. The Haunting Journal of Deward Barnes, Canadian Expeditionary Force: 1916-1919 (Toronto: 2004), p. 60.

${ }^{149}$ Kerry and McDill, The History of the Corps of Royal Canadian Engineers Volume 1, p. 128.

${ }^{150}$ Will Bird, Ghosts Have Warm Hands (Ottawa: 2002), p. 8.

${ }^{151}$ Various, Report of the Ministry. Overseas Military Forces of Canada, 1918. p. 217 ; David Love, "A Call to Arms", p. 110.
} 
major or camp commandant was informed, and bucket lines were to be formed. ${ }^{152}$ While such subjects are often overlooked, clean billets, precautions against fire and sound sanitary arrangements maintained the morale and health of the soldier, which in turn contributed to the fighting efficiency of the Canadians.

The conditions at the front were tolerable at the best of times, but for new recruits Vimy seemed like a nightmare: "the life we led on Vimy was abominable -- always cold and wet -- keeping the trenches in bad condition...our clothes and equipment were continually wet and caked with mud. Working parties of the most disagreeable nature were the order of the day. Night and day, in the most inclement weather these tasks were performed...One instinctively hugged the side of the trench and almost shuddered at the terrific crashing of shells close by."153 When looked at in isolation, the account of this new man is somewhat misleading. By contrast, a veteran of the Somme in the same battalion, the $46^{\text {th }}$, noticed a marked improvement in conditions on the Vimy Front: "although the Germans looked right down on us and gave us lots of mortar and machine gun fire, it was a vast improvement on the Somme."154

Improvements on past experience were being made in many areas. Water supply, was also a consideration for Corps planners as drinking water was essential to maintain the health and efficiency of men and horses. It was also required for baths, laundries and for cooling the barrels of weapons such as Vickers machine guns and artillery pieces.

\footnotetext{
152“Fire Alarm Orders Ranchicourt”, 23 December 1916, LAC, RG 9, III C1, vol. 3879, folder 14, file 2, "Fires (Fire at Canadian Corps. H.Q)."

${ }^{153}$ James L. McWilliams and R. James Steel, The Suicide Battalion (Edmonton: 1978), p. 73.

${ }^{154}$ Ibid.
} 
The water supply system at Vimy, which served the rear area, was designed to provide water for 45,000 horses. Approximately 40 miles of pipe line were layed, along with many engines and pumps, reservoirs were constructed, and horse watering points were established. The forward area of the Corps sector also required water. In March, a spring in Zouave Valley was being developed and an adit, a horizontal mine entrance, was being driven into Vimy Ridge from this spring. A reservoir was excavated and a deep dugout for the engine room and crew also built. A water pipe line was laid along Zouave valley that led into the infantry subways. Engines and pumps were installed at Ecoives Spring, and a pipe line was pushed to La Motte Farm where a reservoir was constructed. From this point, water was to be carried forward by gravity to another protected reservoir that would be furnished with an engine room for the crew. ${ }^{155}$ Sentries were to "prevent animals polluting the source from which the drinking supply is drawn" and ensured no "hostile agent" could poison the entire system. ${ }^{156}$

The pipeline and reservoir system, when it was completed, was extensive and provided enough water for drinking, cooking and horse watering purposes. As mentioned, the pipeline went from the rear areas all the way to some locations in the frontline and into some of the subways. Where water could not be delivered via the pipeline, it was carried up using petrol tins and stored in tanks in the front line before the commencement of the operation. In order to maintain water supply in the area that could be reached by

\footnotetext{
${ }^{155}$ Administrative Arrangements Vimy, 12 March 1917, p. 8.

${ }^{156}$ W.B Lindsay to Canadian Corps, 14 April 1916, LAC, RG 9, III C1, vol. 3891, folder 48, file 9, "Protection of Open Resevoirs Mont Des Cats System"; ibid., W.B. Lindsay to Canadian Corps 'Q' 20 April 1916
} 
German shellfire, it was recommended that pipes be buried seven feet underground.

Furthermore, it was also difficult for water pipes to be laid "as quickly as the advance was made." Staff officers were, therefore, forced to plan for logistical considerations such as water that would be required after the advance occurred. Similar to roads and tramways, it was part of the Canadian Corps attack plan to push water pipes forward, but a more concerted effort was needed in future operations as "material should be held available and personnel should be detailed, awaiting the opportunity to push forward the water supply." 157 A relatively well provisioned and healthy soldiery would be better suited to the forthcoming offensive operations.

The water issue was related to infantry subways. This tunnelling initiative constituted one of the greatest "engineering achievements of the war." Tunnellers dug into the sides of Vimy to excavate thirteen subways, with a total length of close to four miles that led to the front lines. The subways were at least twenty-five feet underground, electrically lit, and provided protection for communications and important logistical features such as water manes. Before the arrival of the Canadians, the British had devised a plan to use tunnels to blow mines under the German positions. Instead, Canadian engineers, enthusiastic about what the tunnels could do, connected, lengthened and enlarged the subways. ${ }^{158}$ They provided vital protection for troops moving to and from the front lines and would be an added advantage to the assault as infantry would remain

\footnotetext{
157“Administration Report Vimy Operations April 1917”, 30 May 1917, p. 7, LAC, RG 9, III C1, vol. 3885, folder 32, file 4. Hereafter Administration Report Vimy Operations.

${ }^{158}$ Herbert Fairlie Wood, Vimy! (London: 1967) p. 86; Michael Boire, "The Underground War: Military Mining Operations in support of the attack on Vimy Ridge, 9 April 1917," Canadian Military History vol. 1 no. $1 \& 2$ (Autumn 1992), pp. 20-21.
} 
unscathed in the tunnels leading up to zero hour. At zero hour, "the mouths of the tunnels would be blown out and the attackers would pour out into...the battlefield." 159 The subways facilitated the efficient evacuation of the wounded via the tramways that ran in the tunnels, which would be important when casualties mounted. Compartments and other chambers were made in the walls and "housed brigade and battalion headquarters, ammunition stores, and dressing stations." There were also several deep caverns, including Zivy Cave, which could hold a full battalion. ${ }^{160}$ The construction of logistical infrastructure was essential in not only providing soldiers with sustenance and ammunition, but also in reducing casualties prior to the commencement of the attack.

The tramways that ran through the tunnels and over open ground were crucial in providing the infantry with ammunition and rations, and were responsible for furnishing the artillery with its shells during the second of two distinct artillery ammunition supply phases, which will be discussed below. The light railway and tramway network that was constructed at Vimy was a logistical watershed in the First World War. The Vimy Ridge operation, part of the larger Arras offensive, was the first instance where the BEF was able to mount an attack with its new transportation policy in place, which saw light railways under army control supplement the Corps level artillery ammunition supply system. Not only was the Canadian effort adequately supplied, but it was a part of a wider series of attacks, evidence of the ability of the BEF, at that time, to provide the ammunition and supply requirements for multiple operations on a broad front. Eric

\footnotetext{
${ }^{159}$ Pierre Berton, Vimy (Canada: 2001), p. 149.

${ }^{160}$ G.W.L. Nicholson, Canadian Expeditionary Force, p. 250.
} 
Geddes, the Director General of Transportation (DGT), discussing the Vimy and the Arras operations, commented on the fact that "for the first time in a major attack the troops in the front line had been supplied with their rations and ammunition supplies on

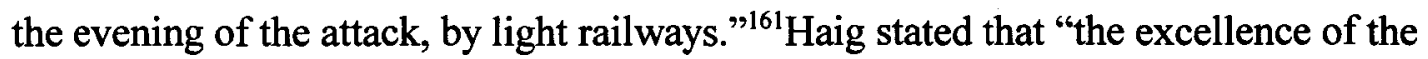
preparations made enabled the concentration to be carried out in a most satisfactory manner and helped appreciably in winning the Battle." 162 While these statements are true, they both fail to take into account the crucial role played by the tramways operated by Canadian Corps troops, and that other elements of the Canadian combined logistics system (lorries, horses and carrying parties) that were in full force while preparations and the operation itself was underway.

The efforts of Eric Geddes to improve the BEF Lines of Communication requires some explanation. Geddes arrived in France in late August 1916 with experience from his previous position at the Ministry of Munitions, and a prewar expertise in railway administration, with the aim of solving the BEF's problem of "how filled shell could best be transported to the front." ${ }^{9163}$ September 1916 saw Geddes appointed Director General of Military Railways and later, at Haig's urging, he became DGT at GHQ. In order to solve the transport problem, it was predicted in November of 1916 that at least 490 locomotives and 3000 wagons would be needed in France in three months, and even more would be required if the BEF successfully advanced into Belgium. The transport problem

\footnotetext{
${ }^{161}$ Ian M. Brown, British Logistics on the Western Front, p. 162.

${ }^{162}$ D. Haig to Eric Geddes, 13 June 1917, LAC, RG 9, III C5, vol. 4449, folder 1, file 2, "Congratulatory Messages June 1917."

${ }^{163}$ Keith Grieves, "Improvising the British War Effort: Eric Geddes and Lloyd George, 1915-18", War \&Society vol. 7 no. 2 (September 1989), p. 44.
} 
could be solved, in part, with the reorganization and supply of rolling stock. First, Geddes negotiated new terms with the French as far as the maintenance and operation of railways were concerned. ${ }^{164}$ Essentially the French had allowed the BEF to "repair and run such railways as [they] f[oun]d necessary"165 Second, through the use of a levy, Geddes garnered rolling stock and tractors from British railway companies and owners in order to provide enough equipment for the new railway infrastructure that he would set about organizing.

The efforts of Eric Geddes in organizing the BEF's transportation system should not be understated, and the supply of commodities was made easier from railhead to Corps tramways by the interposed army light railways. However, the system of providing ammunition and other stores was complex, and much of the delivery of rations, ammunition and various other stores was still up to the tramway operators, lorry conductors, horse drivers, muleteers and carrying parties. The Canadian Corps' continually evolving combined logistical scheme still shouldered much of the burden of battle-area supply.

The newly created army light railways were not always able to provide artillery supply requirements. The transportation of shells to the Canadian Corps Heavy Artillery (CCHA), for example, was still reliant on MT transport in the first phase of ammunition delivery. The supply of ammunition ${ }^{166}$ to the CCHA prior to the Vimy operation was

\footnotetext{
${ }^{164}$ Ibid, p. 46.

${ }^{165}$ Ian M. Brown, British Logistics on the Western Front, p. 161.

${ }^{166}$ There were three types of ammunition: Heavy: For all natures of siege and heavy guns in the Corps Heavy Artillery. Field: For field (light) guns and howitzers of Divisional Artillery. Trench Munitions: Which included rifle and machine gun ammunition, bombs, grenades, and "fireworks" such as flares and
} 
divided into two phases. The first phase supplied the ammunition necessary for the preliminary bombardment and the operations resulting in the capture of the ridge. The second phase provided shot for the operations after the guns had been moved forward from their original positions. During the first phase, ammunition was delivered almost entirely by lorry. It was not until the second phase of the operation that heavy artillery munitions were given priority on the army light railway system, but all batteries that had moved forward of the old Canadian front line during the advance, after 9 April, were served by Canadian Corps tramway lines. The most effective method of supplying heavy artillery shells was via light railway, but problems arose when H.A. shells were not given priority on the system because of demands for the transportation of field artillery shells and engineering material. ${ }^{167}$ It was crucial that heavy artillery batteries were adequately supplied with shells so that their role of neutralising hostile batteries, engaging strongpoints and providing long range harassing fire could be effective. ${ }^{168}$

Roads needed to be constructed in order to supply the heavy artillery pieces effectively in the first dumping phase and to accommodate a whole range of traffic. Prior to the operation three miles of plank road were made and twenty-five more miles of local roads had to be repaired. ${ }^{169}$ Within the Canadian Corps area there were three roads: the Arras-Lens road that ran north from Petit Vimy to Ecurie, the Neuville St. Vaast-Thelus road that ran due east and then down into Farbus and the Souchez-Givenchy road on the

\footnotetext{
signal lights. From Various, Report of the Ministry. Overseas Military Forces of Canada 1918, p. 321.

${ }^{167}$ Brig-Gen. R.H. Massie, "Notes On The Supply Of Heavy Ammunition During the Vimy Ridge Operations", 19 May 1917, p. 1, Administration Report Vimy Operations.

${ }^{168}$ Various, Report of the Ministry. Overseas Military Forces of Canada 1918, p. 242.

${ }^{169}$ Daniel G. Dancocks, Sir Arthur Currie. A Biography (Toronto: 1985), p. 89.
} 
left of the Corps area. Because of shelling, the roads had been destroyed in what had been no man's land and the German trench system. The mine that had been exploded directly underneath the Lens-Arras road formed a huge water filled crater, and much of the other roads' surfaces were covered with mud. After the capture of Vimy Ridge, the weather remained poor and wheeled vehicles cut deeply into road tops. In order to facilitate the forward movement of traffic into the newly won territory, and to help curb the roads' deterioration because of bad weather and wear, working parties were organized for road reconstruction. Under the supervision of the Chief Engineer, between 9 April and 23 April, 5000 men daily, which included infantry, tunnelling companies, labour battalions and field companies, were used in laying, repairing and constructing roads. During this period, 37.9 miles of roadway were repaired and two and a half miles of corduroy road were built. Corduroy roads were fashioned out of two and a half inch beechwood planking that were wired together and rested on frames that were sunk into the surface of the roadbed and "proved most serviceable and of the greatest possible value."170 These plank roads would later be a significant feature during the Passchendaele campaign as well, and were modelled on the corduroy roads of Ontario that were used to negotiate muddy or swampy areas. ${ }^{171}$

In the 1st Divisional area, Major-General Arthur Currie stated that his sector had no forward roads beyond the Arras-Bethune road, and that the plank or corduroy road from Ariane to the Lens-Arras road was well built by the engineers. Unfortunately, the

\footnotetext{
${ }^{170}$ War Diary Report Vimy, p. 34.

${ }^{171}$ Bill Rawling, Technicians of Battle, p. 30; Daniel Dancocks, Legacy of Valour, p. 107.
} 
road was comprised of a single lane creating traffic jams. After the end of the road was reached, there was no other road until the La Targette-Thelus road was finished. This delayed "the getting forward of heavy guns and howitzers, field guns and howitzers, and gun and howitzer ammunition." ${ }^{\text {"172 }}$ In future operations, Currie suggested that two labour battalions besides the pioneers should be assigned to each division to build forward roads if operations were to be carried out in bad weather such as that experienced at Vimy. This was a harbinger of the operations to come at Passchendaele, and while attention was paid to road construction at Vimy and made the dumping of ammunition more efficient, it was not without its problems and there was still considerable room for improvement. Horse transport driver James Johnston could vouch for the effectiveness of plank roads: "the engineers soon had a sort of corduroy road laid through the shell holes, which helped a lot getting the limbers along." ${ }^{\prime 17}$ The plank road, for example, was a uniquely Canadian solution to the logistical problems that were faced by the Corps at Vimy, and while road construction was hampered by enemy shelling, poor weather and the massive amount of traffic that the roads had to handle, the Canadians nonetheless made communications in the battle area a priority, both prior to and during the advance after zero hour.

At zero hour, the firepower generated by one heavy gun for every twenty yards of front and one field gun for every ten yards was overwhelming. Closely following the barrage, and protected by excellent counter-battery work, the infantry steadily advanced. After hard fighting, three of the Canadian divisions had reached the top of the ridge by

\footnotetext{
${ }^{172}$ Maj.-General A.W. Currie to Canadian Corps, 19 May 1917, Administration Report Vimy Operations.

${ }^{173}$ James Johnston, Riding into War, p. 46.
} 
the afternoon of 9 April 1917. The heavily fortified Hill 145, in the $4^{\text {th }}$ Division's area, would fall to the Corps three days later. ${ }^{174}$

Shortly after the first day's barrage was completed, Ernest Black's artillery battery was ordered to advance down a one-way road after engineers and pioneers had constructed what he calls a fascine road, which was a variation on the corduroy road concept, built with bundles of branches laid side by side in the mud to fashion a one-way lane. Black states:

Just at dusk we started forward, our party consisting only of our six guns and a transport wagon with rations. We had not gone very far when we found that someone had blundered. The road came to an end in front of what had been the old German line, right where our shelling had been the heaviest and where the quagmire was the worst. The first gun off the fascines demonstrated the impossibility of further progress. The horses went down into the mud to their bellies and the gun sank down to its axle. There was nothing to do but turn around and go back. ${ }^{175}$

A working party supervised by Major Harry Crerar sustained 50 percent casualties while laying a road, but it was necessary work and as a result, his gunners were able to haul their artillery pieces to their newly won position on top of the ridge. ${ }^{176}$ Although there were difficulties and setbacks during the Vimy operation like those experienced by Black and attested to by Currie, the Vimy operation provided important lessons and the logistical code had been broken. Such attention to logistical detail made the Canadian Corps an efficient offensive weapon and the experiences at Vimy would inform their logistical decisions in the coming battles of 1917 and influence the nature of the re-

\footnotetext{
${ }^{174}$ Terry Copp, "The Military Effort, 1914-1918", in David MacKenzie, (ed.), Canada and the First World War (Toronto: 2005), p. 52.

${ }^{175}$ Ernest G. Black, I Want One Volunteer (Toronto: 1965), p. 94.

${ }^{176}$ Tim Cook, No Place To Run, p. 110.
} 
organization of the Corps in 1918.

The Canadian Corps combined logistics system was not exclusively reliant on any one mode of transport as MT was still used to supply the needs of the Heavy Artillery, especially in the first logistical phase. The operation at Vimy revealed that the movement of shells was done most efficiently over the light railway system, but lorries were needed to supply batteries that were not sited near the railway tracks and were also used as a reserve supply system if the light railway broke down. MT could also supplement rail supply during periods of heavy firing because it was difficult for light railway alone to provide an adequate supply of ammunition for guns that were firing 800 to 1,000 shells a day. ${ }^{177}$ The value of establishing a combined logistics system, which relied on a number of transport means, enabled the Canadian Corps a degree of flexibility as far as their supply arrangements were concerned and enabled supplies to flow even if one mode of transport broke down, could not cope with supply demand, or was interdicted by German shelling.

The MT formation that was responsible for supplying the heavy artillery with its shells directly from the broad-gauge railhead, during the first stage of supply, was the Canadian Corps Siege Park. The Siege Park was manned by imperial personnel, but was under Corps control and had a large establishment of both men, lorries, and four wheel drive tractors. ${ }^{178}$ The modifications that the Canadians had made to their Corps logistics

\footnotetext{
${ }^{177}$ Brig-Gen. R.H. Massie, "Notes On The Supply Of Heavy Ammunition During the Vimy Ridge Operations",19 May 1917, p. 1, Administration Report Vimy Operations.

${ }^{178}$ Ibid, p. 2. At Vimy, the Siege Park comprised: 996 lorries, 104 F.W.D. Tractors. 80 Caterpillars and 9 Workshops. Of the 996 lorries, 27 were store and workshop lorries, and approximately 400 were out of action, and another 150 daily were requisitioned by the Corps. Of the remaining 419 , roughly 70 were in
} 
system were innovative, but in certain instances the BEF supplied both additional transport and personnel to aid in the daunting task of preparing for major assaults.

The system adopted for the second phase of the ammunition supply operation, as far as heavy artillery was concerned, featured light railways, tramways and lorries. Following the capture of the ridge, it was extremely difficult to supply artillery batteries that had been pushed forward from their original positions with lorries. Because of these supply problems, the Heavy Artillery was given priority on the light railways and tramways. R.H. Massie stated: "after the experience of the operations in the Salient of June 1916, the Somme and the Vimy Ridge, the system now in force in the Canadian Corps appears to be the best that has yet been evolved." 179 The system commenced at two railheads. Ammunition sent to each of the railheads would be cleared by army light railway and carried to two transhipping points, which would feed different areas. From these two points, commodities could be moved to the Corps tramways, and then to the guns. There was also a lorry dump located at the broad-gauge railhead. The tramways not only transported shells forward, but the guns themselves were moved to new positions over their rails. Massie concluded that it was more efficient to transport 6" and 8" Howitzers over the light railways and tramways, since they could be constructed over broken ground faster than roads. Despite poor weather and muddy, shell torn ground, 10

\footnotetext{
daily use for rations and r.e. material, which reduced the number of lorries available for ammunition transport to 350. For the 3 days before zero extra lorries were lent by Army. The tonnage hauled to the guns from the $5^{\text {th }}$ to $11^{\text {th }}$ April was -5 April: 933 tons, $6^{\text {th }}: 1442$ tons, $7^{\text {th }}: 1288$ tons, $8^{\text {th }}: 1598$ tons, $9^{\text {th. }}$ : 1740 tons, $10^{\text {th. }}: 1362,11^{\text {th: }}: 1429$. Lorries carried $95 \%$ of the total HA shells in the first ammunition buildup.

${ }^{179}$ Brig-Gen. R.H. Massie "Notes On The Supply Of Heavy Ammunition During the Vimy Ridge Operations",19 May 1917, p. 3, Administration Report Vimy Operations.
} 
April saw Corps tramway personnel begin to push a rail-line forward to newly captured Thelus, which was 5000 yards away. Within 10 days, the rails had carried 180 tons of ammunition into the city. These types of shells weighed over 100 pounds and were difficult for pack transport to handle. For future operations, Massie recommended that an officer and working party should be stationed at each transhipping point in order to organize the dump. ${ }^{180}$ If tramlines were destroyed, brigades were prepared to use their first line transport, if possible, or if not, the Divisional Pack Mule Company to supply ammunition. ${ }^{181}$

Canadian Corps Tramways served all manner of functions. Even though the light railway and tramway system had already been extensive prior to the build up for the Vimy attack, 5,000 yards of additional tramline was laid. At its peak, the tram network constituted 20 miles of track with an optimum daily carrying capacity of 830 tons. Tramway rolling-stock under Canadian Corps control was moved by petrol-electric tractors or by mules that were supplied by the DAC. Trams eased the supply burden for the DAC as spurs off the main tramway lines went directly to battery positions, and if a change of position was necessary, it was possible to construct a new spur overnight enabling ammunition to flow to the position before dawn. Such a line was completed by the end of February 1917. Powered by mules, the line ran through the trenches of Aux Rietz and by Neuville St. Vaast, which was approximately 2,000 yards from the German

\footnotetext{
${ }^{180}$ Brig-Gen. R.H. Massie "Notes On The Supply Of Heavy Ammunition During the Vimy Ridge Operations", 19 May 1917, pp. 2-3, Administration Report Vimy Operations.

${ }^{181}$ War Diary, $3^{\text {rd }}$ Canadian Division, General Staff, Appendix 601, p. 70, LAC, RG 9, III D3, vol. 4853, microfilm, reel T-1934, file 139.
} 
front lines. At this point the line supplied forward artillery batteries with shells. ${ }^{182}$ By 23 April, the tramways had been advanced more than 21,000 yards and the standard gauge railroad was constructed with "commendable speed" beyond the Arras-Bethune Road. ${ }^{183}$ Many of the subways featured tramways, and bombs, rations, ammunition and other items were transported over their rails to special store rooms in the tunnels. After the attack went through, "tramways proved invaluable. They were laid on a very rough roadbed, and were far in advance of road construction. Guns, ammunition and rations were taken in over them, and wounded brought out." ${ }^{184}$

Even from a medical point of view, the assistance of Canadian Corps tramways served to convey wounded men to forward dressing stations much more quickly than if stretcher bearers alone were used. Through their use, "great numbers of stretcher cases were rushed down to various points with a maximum of speed and a minimum of discomfort." The $4^{\text {th }}$ Division used trams to transport wounded from their regimental aid posts to the door of the Main Dressing Station in some cases. This took pressure off the ambulance cars that were freed to handle other cases. ${ }^{185}$ There were difficulties, however, with the prioritization of traffic and this was one of the main problems after the advance had been successful and artillery needed to be brought forward. In future operations, the Corps considered delaying the columns in order to let wounded cases by, and arranging

\footnotetext{
${ }^{182}$ Kerry and McDill, The History of the Corps of Royal Canadian Engineers Volume 1, p. 129.

${ }^{183}$ War Diary Report Vimy, p. 34.

${ }^{184}$ Maj. J.M. Rolston for C.E., Canadian Corps to Canadian Corps 'Q', 20 May 1917, p.2, Administration Report Vimy Operations.

${ }^{185}$ Major [?],"Comments on the Working of the Medical Arrangements at the attack on Vimy Ridge by the Canadian Corps", 17 May 1917, Administration Report Vimy Operations.
} 
for motor ambulances to be standing by. ${ }^{186}$ These were the kind of hard choices the Canadian Corps had to and did make.

The assault on Vimy Ridge was a success. The often overlooked realm of logistics had come into its own at Vimy. The Canadians, while working closely with their British allies, had devised a combined system that, despite its problems, emphasised an elasticity whereby interdicted modes of transport were backed up by another system during the build up for the operation. Horse transport, motor lorries, pack transport, light railways and tramways were all used by the Canadian Corps to support the infantry, artillery and engineers with everything they needed to insure that the attack would be a successful one. Not only did these considerations figure heavily during the build up for the battle, but logistical considerations were paramount in the minds of staff planners during the assault. The evolution of the combined logistics system continued as lessons were gathered from the Vimy experience that would serve them well in the future battles of 1917.

In total, 40,000 infantry fought in the assault from 9-12 April, and of that number 3,598 were killed and 7,004 were wounded. ${ }^{187}$ If the preparations for the battle had not been so extensive, and if the willingness had been lacking to expend the maximum effort necessary to insure that the infantry was given the most protection that could be afforded to it, those casualty numbers would have been far worse. The objective of capturing the ridge would not have been attained had planning been poor and logistical considerations not been foremost in the minds of the staff.

\footnotetext{
${ }^{186}$ Ibid.

${ }^{187}$ J.L. Granatstein and Desmond Morton, Canada and the Two World Wars (Toronto: 2003), p. 91
} 
After the success at Vimy Ridge, the BEF had attack plans in mind for Arthur Currie who replaced Byng as Corps Commander. As a diversion to fix German reserves from reinforcing their northern positions in Flanders, Sir Henry Horne's First Army was to target Lens, a few miles to the north of Vimy Ridge. Horne in turn delegated the task to Currie and, on 7 July, ordered him to capture the mining city. ${ }^{188}$ Currie reviewed the attack plan for Lens, but preferred a different approach, pointing out that Hill 70 was the most important tactical feature in the area that dominated Lens. If the Canadians took and held the heights, the Germans would be forced to either counter-attack or withdraw from the city because the hill was an excellent vantage point that looked far into German-held territory. Currie's attack plan was designed to destroy German counter-attacks with artillery and well dug in infantry. ${ }^{189}$ During the summer of 1917 , he emphasized the need to furnish his infantry with every means of support available. From an artillery point of view, and therefore a logistical one as well, this was achieved: the infantry had the benefit of more than double the rates of ammunition expenditure achieved in other formations. ${ }^{190}$ Not only would artillery power protect the infantry, but it would destroy German counter-attack divisions in their assembly areas. Hill 70 was taken on 15 August, and as many as twenty-one counter-attacks were shattered by Canadian machine-guns, artillery and small arms fire from infantry who had strongly consolidated their positions. The attack was a success, but had been one of the hardest fought engagements of the

\footnotetext{
${ }^{188}$ Daniel Dancocks, Sir Arthur Currie, pp. 103, 105.

${ }^{189}$ Ian M. Brown, "Lieutenant-General Sir Arthur Currie and the Canadian Corps 1917-1918: The Evolution of a Style of Command and Attack", pp. 36-37.

${ }^{190}$ A.M.J. Hyatt, General Sir Arthur Currie, p. 98
} 
war. ${ }^{191}$ The ten day battle resulted in 9,198 casualties for the Corps; in return, five German divisions were badly mauled in the fighting and the allies could observe and dominate the Douai Plain from their newly won position. ${ }^{192}$

Canadian logistical services were harassed mercilessly during the battle of Hill 70 . Horse transportation was acutely affected as German gas shells were fired into the Canadian lines of communication to create disorder and cause casualties in the transport units. The animals were often lethally gassed as their drivers looked on in vain: Richard Adamson "could do nothing as he sat with his respirator attached and listened to his horses make screaming sounds as they were being poisoned." In order to ease the casualty rate and because supplies and ammunition had to continue to flow to the front lines, gas masks for horses were introduced in May 1917 that, despite their benefits, caused the horses discomfort as they struggled for breath while their heads were covered with the apparatus. Because mustard gas could contaminate large areas for several days and was a blister agent, horses and mules, even if they were wearing gas masks at the appropriate time, developed sores, went lame and, in time, were blinded by the effects of the gas. ${ }^{193}$ The efforts to alleviate the strain on transport animals and the Germans' attempts to slow the movement of commodities to different locales in the battle area are a testament to the importance of logistics, and despite the attempts to make life intolerable the supply services continued to work.

\footnotetext{
${ }^{191}$ Ian M. Brown, "Lieutenant-General Sir Arthur Currie and the Canadian Corps 1917-1918: The Evolution of a Style of Command and Attack", pp. 36-37.

${ }^{192}$ J.L. Granatstein, Canada's Army Waging the War and Keeping the Peace, p. 121.

${ }^{193}$ Tim Cook, No Place To Run: The Canadian Corps and Gas Warfare in the First World War, p. 133.
} 
The battle for Hill 70 was similar to the set-piece battle at Vimy, and the logistical build-up for the attack fit the same mould. The difference at Hill 70 was at the tactical end where twenty-one counter-attacks were fended off by Canadian guns and infantry, as opposed to Vimy where local resistance was fierce, but no large scale counter-attacks occurred.

The Canadian Corps' success at Hill 70 lead to GHQ's decision to move the Corps to Passchendaele on 9 October 1917. Without much delay, the Canadian General Staff issued orders to prepare for the move. Corps Headquarters itself was to be relieved by V Corps before it transferred to Second Army, while the $4^{\text {th }}$ Canadian Division was to be moved, less its artillery, into the Steenbecque area on 11/12 October, and four of its battalions would be transported by 'tactical train', on the broad-gauge rail system, from Houdain and Bruay on 12 October 1917. Busses from First and Second Armies would also be provided to transfer three battalions on the 11 and 12 October. These arrangements were made by the First Army's and the Canadian Corps' administrative staff. While the infantry were being ferried to their new location in the Second Army, their transport would be forced to march the same distance beginning on the $11^{\text {th }}$ of October by brigade groups. The $3^{\text {rd }}$ Canadian Division was assigned similar move arrangements that would see its battalions carried by road or rail to their new destination. In this case, like the transport, the $3^{\text {rd }}$ and $4^{\text {th }}$ Divisional Artilleries were ordered to march north to Flanders. ${ }^{194}$ Moves and reliefs of divisions and Corps were complex operations.

\footnotetext{
${ }^{194}$ War Diary, Canadian Corps General Staff, "Canadian Corps Operation Order NO. 155", 9 October 1917, LAC, RG 9, III D3, vol. 4816, microfilm, reel T-7177, file 13.
} 
Without competent staff officers both in the General Staff and in the administrative branches of the Canadian Corps, along with various Imperial formations, it would have been impossible for the BEF to successfully transfer units from one area to another. Generally speaking, the movements of formations in the BEF can be divided into five categories:

a)Maintenance movements, i.e. the transport of ammunition, supplies and other commodities towards the troops in action;

b)Normal evacuations of sick and wounded, damaged material and salvage back to the bases;

c)Strategical moves of reinforcements to or from any particular part of the front;

d) Tactical movements inside the area of each Army;

e) The very difficult movements involved in the withdrawal during serious operations of heavy artillery, depots and dumps of stores, and establishments, from one zone to the next in rear. ${ }^{195}$

In preparation for the move, Currie stationed intelligence officers with the headquarters of Second Army and II Anzac Corps along with its divisions, the New Zealand and $3^{\text {rd }}$ Australian Division, in order to acquire information about German defences and help prepare future attack plans. In terms of the relief, this early consultation with the Australians allowed it to go more smoothly: "Corps and Divisions were so thoroughly in touch with the situation that, on the day on which they became responsible for the line, the actual handing over was merely a matter of form." 196

The sector that the Canadian Corps took over from the Anzacs on 18 October was similar to the one they had held in 1915 , but the conditions were far worse. The Canadians' front was situated on the valley of the Stroombeek between Gravenstafel

${ }^{195}$ Colonel A.M. Henniker, Transportation on the Western Front, 1914-1918 (London: 1937), p. 356.

${ }^{196}$ Daniel G. Dancocks, Legacy of Valour The Canadians at Passchendaele, p. 99. 
Ridge and the heights around Passchendaele. The only two recognizable landmarks since their last visit to the salient were the Ypres-Zonnebeke-Passchendaele road and another parallel route that passed through Gravenstafel. The cities of St. Jean, Wieltje and Fortuin, along with woods and farm-houses had been destroyed. The drainage of both the Ravebeek and Stroombeek had been shattered by shellfire and many portions of the front were reduced to bog-like conditions. Currie commented in his diary that the battlefield was in a poor state and "no salvaging ha[d] been done and very few of the dead buried." ${ }^{\text {197 }}$ Planning for an operation in such conditions would press the logistical system to its utmost.

The poor state of the battlefield was complicated by the narrowness of the Corps area. The BEF had been hammering its way into the salient for two months prior to the Canadians' arrival, and as a result created a logistical bottleneck because all supplies in the sector were restricted to only a few routes. At the base of the forward area, there was considerable traffic as transport units funnelled into the rear areas of the battlefield. The efforts required to supply the men and guns, which were in and near the front, were considerable, and the link between the far forward area and the rear was precarious. The Germans, whose artillery dominated the salient, realized the importance of the rearward logistical network for the troops at the salient's tip and their guns regularly searched the area to destroy personnel and infrastructure such as tramway tracks and roads. Away from

\footnotetext{
${ }^{197}$ G.W.L. Nicholson, Canadian Expeditionary Force p. 312-313; Because the presence of dead bodies on the battlefield were such a detriment to morale, new burial instructions were issued after the battle. See "Canadian Corps 'A' Burial of the Dead. Divisional Instructions re.", 1 January 1918, LAC, RG 9, III Cl, vol. 3877 , folder 8 , file 5 .
} 
this bottle-neck, the BEF's supply system continued to function quite well up to the broad-gauge railhead. ${ }^{198}$ However, it was in the forward area, beyond those railheads that the resupply efforts were most difficult and this is where the Canadian Corps' combined logistic system needed to be established in order to insure that the objectives assigned to it were attained.

Historian Ian Brown has stated that what the BEF should have done to counteract German artillery fire that targeted logistical conduits was to develop a mixed supply system whereby light railways, which were most effective in transporting heavy artillery shells, were used in areas that were subjected to only moderate shelling, while in areas that were readily interdicted by German efforts, lorries should have been used. ${ }^{199}$ This is precisely the logistical system that the Canadian Corps had developed by the time it had reached the Vimy Ridge battle, and it was to be put into place, once again, to gain the Corps' Passchendaele objectives. However, in order to allow the Corps to bring adequate firepower to bear, and allow the infantry to move over the shattered landscape, the necessary infrastructure needed to be constructed.

Crucial to the battle's success was the creation of infrastructure in order that the combined logistics system could function, even in these terrible conditions. In addition to being in a narrow salient, the rear areas that the Canadians took over were on ground shattered by the previous months' shelling and the movement of artillery, infantry and logistical vehicles was severely hampered. Because the nature of the ground was so poor,

\footnotetext{
${ }^{198}$ Ian M. Brown, British Logistics on the Western Front, p. 172.

${ }^{199}$ Ibid, p. 173.
} 
and there were an inadequate number of roads in the area, the artillery pieces were grouped together very closely, which afforded the Germans excellent targets. Prior to the Canadians' arrival, a few artillery batteries had managed, by means of tremendous effort, to move their guns forward into the morass, only to find themselves out of supply range. The Canadians realized that "until such time as roads and light railways were developed it was impossible to support further operations or to obtain a proper percentage of power from the artillery available." ${ }^{200}$ Similarly, a Corps report concluded that "at least $25 \%$ of the artillery power available was lost owing to the scarcity of roads and railways." The lack of roads not only forced the batteries to be grouped together closely, but the manhandling of guns in such poor conditions also exhausted the crews, reducing efficiency. ${ }^{201}$

Currie stated that it was crucial that, before the infantry was committed to the assault, their commanders must be confident that German defences, especially wire, were adequately cleared. ${ }^{202}$ In order to successfully deal with hostile wire, artillery was required in great numbers, and to insure that the guns were in range of these targets, they had to be able to move forward to advantageous positions. One way to make this happen was to build plank roads and push a tramway line forward. That task would fall to the engineers, pioneers and attached labour units that worked unceasingly in the mud and squalor.

Roads were an integral part of the logistical network necessary to move all sorts of

\footnotetext{
${ }^{200}$ Ian M. Brown, "Lieutenant-General Sir Arthur Currie and the Canadian Corps 1917-1918: The Evolution of a Style of Command and Attack", p. 40.

${ }^{201}$ Daniel G. Dancocks, Legacy of Valour The Canadians at Passchendaele, p. 105.

${ }^{202}$ Ibid, p. 99.
} 
vehicles and personnel. In the salient, there were only three roads capable of carrying MT, along with two others that were suitable only for pack animals. Currie believed that roads constituted "an essential to victory" and the Corps would again employ plank roads as it had done at Vimy. A hastily-constructed sawmill behind the lines would supply the planks necessary to construct corduroy roads. Even though this Canadian innovation was initially rejected by the British, it was later adopted along the entire BEF front. ${ }^{203}$ It spoke to the Corps' ability to use methods unique to the Canadian pioneering experience in order to improve their logistical situation.

Road work was difficult and the German artillery made life miserable for those laying the new routes. Under the direction of W.B. Lindsay, the Chief Engineer, the $1^{\text {st }}$ Canadian Division's three engineer companies, a pioneer battalion and attached infantry working parties built a road forward. They worked twenty-four hours a day in four, six hour shifts. The road was built by digging embankments and ditches, then the centre was filled with sandbags and planks. ${ }^{204}$ This road made it possible to get supplies of ammunition, road material, R.E. Stores, heavy gun ammunition, and other items forward. It was continually subjected to shell fire, with several direct hits being made on it. ${ }^{205} \mathrm{By}$ 30 October, Panet Road had been extended as a double plank road to Kansas Cross, and as a single road about 200 yards further. ${ }^{206}$ Until 3 November, the rate of construction

\footnotetext{
${ }^{203}$ Daniel G. Dancocks, Legacy of Valour The Canadians at Passchendaele, p. 107. ${ }^{204}$ Ibid, p. 108.

205، Administrative Report in Connection With the Operations of the 1st Canadian Division At Passchendaele Ridge November 1917," 7 December 1917, LAC, MG 30, E 54, F.R. Phelan Papers, 2.15.

${ }^{206}$ “6 1 st Canadian Division-Administrative Instructions For Operations in Flanders October-November, 1917', Instructions No.9. Roads, 30 October 1917, LAC, RG 9, III C1, vol. 3885, folder 32, file 5, "Passchendaele October November 1917". Hereafter 1" Division Administrative Report.
} 
had achieved the rate of 375 yards a day until it crossed Honnebeek stream, west of Gravenstafel, at which time it came in full view of German artillery observers. From that point on, work was often disrupted by artillery fire as the workers scattered to avoid being hit. The road work was exhausting, dangerous and at times horrible: "the ground was covered with bodies making grading very unpleasant." ${ }^{207}$

The plank roads were necessary to both move and supply the artillery necessary to engage targets and support Canadian infantry in the assault. However, engineers and pioneers also required wood for constructing firm wooden platforms for the guns, ${ }^{208}$ and for making duckboard footways that served as infantry tracks, which would allow soldiers to move around the battle area. Engineers also found that during their construction operations, the wooden planks for the corduroy roads were well fastened, but the bathmats that were used to make the foot tracks were often stolen by soldiers who were bent on improving their living conditions. ${ }^{209}$ Despite this, duckboards snaked across the battle area:

my own memories of Passchendaele are limited, though still vivid. There were the endless duckboard tracks, winding erratically towards the front. To leave them was to sink into a slough. As far as the eye could see, through rain or generally misty autumn air, there were shell craters, great and small, in patterns which so many have compared to the moonscape. ${ }^{210}$

The conditions in the salient called for these footways, and, without them, movement was difficult owing to the clinging mud and the danger inherent in slipping into water-filled

\footnotetext{
${ }^{207}$ Daniel G. Dancocks, Legacy of Valour The Canadians at Passchendaele, p. 108.

${ }^{208}$ J.L. Granatstein, Canada's Army. Waging War and Keeping the Peace, p. 123.

${ }^{209}$ Kerry and McDill, The History of the Corps of Royal Canadian Engineers Volume 1, p. 142.

${ }^{210}$ E.L.M. Burns, General Mud. Memoirs of Two World Wars, (Toronto: 1970), p. 57.
} 
shell craters. John Becker, an infantryman with the $75^{\text {th }}$ Battalion, had a hand in making these wooden paths. Lorries would dump the six-foot lengths of trench mat at the side of the road, each man of the working party would take up a piece of mat and follow the wooden path to its end, lay down his section and then return to the roadside dump for another piece. German artillery would often destroy the paths even while they were being constructed: "Frequently we would carry our quota for a couple of miles to the end and returning for another load, find the Germans had already got the range of the path and blown up the route in two or three places. We would skirt the shell holes with great difficulty and repair the gaps with new mats on the way back. All this work was carried out under continuous shell fire and casualties were heavy."211 Aside from the enemy's best efforts to impede the work, the duckboard tracks were extended ever forward to connect to the front lines.

Light railways and tramways were also a feature of the Ypres salient and remained part of the combined logistical net. At Passchendaele, Currie was unimpressed with the performance of the army controlled light railways in the area. He felt that the army personnel manning the light railways, which operated in the rear of the Corps area, were inefficient when under fire because of "their semi-civilian nature." After the battle, he noted that Corps troops should man the light railways instead and that the Corps should form their own light railway company. ${ }^{212}$ Two of the Corps' most successful artillery

\footnotetext{
${ }^{211}$ John H. Becker, Silhouettes of the Great War, p. 122

${ }^{212}$ Ian M. Brown, British Logistics on the Western Front p. 172; Ian M. Brown, "Lieutenant-General Sir Arthur Currie and the Canadian Corps 1917-1918: The Evolution of a Style of Command and Attack", p. 40.
} 
officers, Andrew McNaughton and Edward Morrison, attested to the inefficiencies of the army controlled light railways: "there were cases where light railway teams, bringing the ammunition up, came under bombardment well back and dumped the shells off the cars. It would be reported in returns as expended, when it was actually thrown in the mud."213 Currie insisted on getting the ammunition through, and it was the engineers, pioneers and labourers of the Canadian Corps who pushed tramway lines farther into the salient. ${ }^{214}$ In the end, road and tramway work cost the Corps 1,500 casualties. ${ }^{215}$

Even though the plank roads were crucial to the movement of ammunition and supplies for the artillery by means of lorries and wagons, commodities for the front line troops had to be transported by carrying parties over duckboards, as Corporal John Becker explained:

Wheeled traffic could not reach the usual proximity to the line. Plank roads were laid for a distance but were being constantly blown up by enemy shelling. From the end of the wagon roads, pack mules were used for a further distance but even they became mired a little closer up and beyond that there was nothing but broad backs of the dirtiest, lousiest, most dilapidated looking bunch of troops that one could imagine. I carried tons of stuff during my sojourn on this front. The only thing that saved us from annihilation was the same mud that hampered us and held us and almost starved us. The artillery fire was terrific day and night but the ground was so soft that it was said only about $1 / 3$ of the shells exploded. They did not meet enough hard surface resistance to detonate. Most of those that did explode by percussion burst so far under the surface that their effectiveness was lost. We were splattered with great seas of mud and water and thus many piece of steel did not reach a mark. The only really successful shelling was from shrapnel on fuses timed to burst just overhead, and from gas. ${ }^{216}$

Carrying supplies forward to units in the front line remained dangerous and exhausting

\footnotetext{
${ }^{213}$ Daniel G. Dancocks, Legacy of Valour The Canadians at Passchendaele, p. 108.

${ }^{214}$ Daniel G. Dancocks, Sir Arthur Currie, p. 113.

${ }^{215}$ Ian M. Brown, British Logistics on the Western Front, p. 168.

${ }^{216}$ John H. Becker, Silhouettes of the Great War, p. 120.
} 
work, but was necessary to keep the troops from going hungry and running short of ammunition.

Despite the horrible conditions and German efforts to slow down logistics, the combined system continued to function. Sufficient roads had been constructed in order to get the crucial artillery support in position. In fact, Currie delayed his attack to accommodate the essential logistics. Only after these necessary preparations were made could the attack go forward.

The Corps launched its attack on 26 October 1917. The first stage failed to reach its objectives, although it had managed to improve the jumping-off positions for future attacks. These efforts, however, came at a high cost in casualties to the assault troops. In order to supply the frontline soldiers in their newly won positions with ammunition, rations and other supplies, the engineers, pioneers and labour pushed plank roads forward, one for each brigade sector, so that the brigade pack trains could ferry supplies onward. These preparations were made under fire, day and night, to enable the logistical net to support the new front line in preparation for the next attack on 30 October. ${ }^{217}$ Victor W. Wheeler had the opportunity to lead a mule-train that was carrying 18 pounder shells, and praised the animals: "that unsung hero the army mule, seemed to strangely ignore the danger of its job. Whether it was pulling heavy cannons, hauling weighty wagonloads of construction materials, rushing steaming field kitchens up to the front, or packing dangerous ammunition to forward dumps...it was very rare we had trouble with them

\footnotetext{
${ }^{217}$ G.W.L. Nicholson, Canadian Expeditionary Force, p. 320.
} 
under fire." ${ }^{218}$ Thanks in large part to the buildup and forward movement of supplies, which were facilitated by pack animals and their drivers, the attack on 30 October could occur. That day, the line advanced another thousand yards. The cost, again, was high with 2,300 casualties, but would likely have been far higher without the supporting logistical network. ${ }^{219}$

After the infantry had consolidated their line, a week long pause in the operation was observed, and the $1^{\text {st }}$ and $2^{\text {nd }}$ Canadian Divisions relieved the $3^{\text {rd }}$ and $4^{\text {th }}$ in anticipation of the last series of attacks on Passchendaele. In preparation for the next assault, some artillery field batteries worked their way forward to new positions closer to Gravenstafel ridge. The $2^{\text {nd }}$ Canadian Heavy Battery used a newly built narrow-gauge railway line to move their 60-pounders 3,000 yards closer to Gravenstafel: "four guns left for forward position, to go up by light railway. Owing to enemy shelling, railway was put out of commission after first two arrived." The other two guns were eventually brought up on the following day (3 November 1917) presumably after repairs to the line were made ${ }^{220}$ Ammunition supply continued as horses and men struggled against the mud and shellfire. During the pause, an estimated 15 to 20 horses had to be hauled out of the mud after they had fallen off the plank roads. Many of those that were recovered had to be put down. ${ }^{221}$ In spite of these challenges, the combined logistics system at Passchendaele

\footnotetext{
${ }^{218}$ Victor W. Wheeler, The $50^{\text {th }}$ Battalion In No Man's Land, p. 169.

${ }^{219}$ John Swettenham, To Seize the Victory (Toronto: 1965), p. 188.

${ }^{220}$ War Diary, $2^{\text {nd }}$ Canadian Heavy Battery, 2 to 3 November 1917, LAC, RG 9, III D3, volume 4977, microfilm, reel T-10805, file 580 .

${ }^{221}$ G.W.L. Nicholson, The Gunners of Canada, volume 1, p. 309.
} 
managed to get batteries moved forward, which was essential to support the infantry in further phases of the battle as they moved out of previous artillery range. The logistical units allowed these new positions to be supplied with ammunition in the worst possible conditions.

After Passchendaele was captured on 6 November, Currie outlined several key factors that contributed to the Corps reaching its objectives. Currie praised the fighting spirit of his men and their training. However, along with the accomplishments of the fighting arms, the next two elements that he mentioned related to logistics: the extra preparation time that he had been given insured that improvements to logistical infrastructure could be made. These improvements allowed the artillery to be supplied with the ammunition necessary to support his attacking troops. Currie further stated that the roads and tramlines built, maintained, and operated by the Canadian Corps were crucial in supplying his forces. ${ }^{222}$ Without their excellent logistical ability, the Canadians would not have been able to attain their objectives. It was through ingenuity, hard work, determination, and a good deal of suffering that the Canadians were able to overcome the worst conditions imaginable.

${ }^{222}$ Ian M. Brown, "Not Glamorous, But Effective: The Canadian Corps and the Set-Piece Attack, 19171918" The Journal of Military History vol. 58, no. 3 (July 1994), p. 429. 


\section{Chapter Three}

\section{The Combined Logistics System and the Last Hundred Days, 1918}

After the Passchendaele offensive, the Canadians were pulled out of the line and spent the winter fortifying their positions around Vimy Ridge. The Western Front had once again returned to static warfare, yet this was not to last as the Germans launched a massive offensive push of their own. Behind a barrage of high explosive, shrapnel and poison gas, in the early morning of 21 March 1918, waves of German infantry engaged Sir Hubert Gough's Fifth Army and Sir Julian Byng's Third Army. ${ }^{223}$ The two British armies broke in the face of overwhelming firepower, superior German numbers and their spearhead units' employment of innovative infiltration tactics. The German forces managed to penetrate 40 miles through the British front and capture over one thousand square miles of ground before the opening phase of the operation ended on 5 April, $1918^{224}$

Despite their gains, achieved through tactical innovation, the Germans had ongoing logistical problems during their offensive. Their largely defensive stance on the Western Front, prior to the March Offensive, had not given them adequate experience in logistics during an advance. Even though the Germans had punched deeply into allied lines, their logistics were forced to traverse the now cratered and water logged ground, which made the forward movement of supplies, artillery and fresh divisions very difficult.

\footnotetext{
${ }^{223}$ Tim Cook, No Place To Run: The Canadian Corps and Gas Warfare in the First World War, p. 169.

${ }^{224}$ Tim Travers, The Killing Ground: The British Army, the Western Front and the Emergence of Modern Warfare, 1900-1918, (London: 1987), p. 220; Bruce I. Gudmundsson, Stormtroop Tactics. Innovation In The German Army, 1914-1918 (Westport, Conn.: 1989), pp. 162-168; John A. English and Bruce I. Gudmundsson, On Infantry. Revised Edition (Westport, Conn.: 1994), p. 29.
} 
When operations ceased, the Germans were in defensive positions amidst the old mudfilled trenches of the Somme, with little shelter from the severe British shelling. The German $18^{\text {th }}$ Army, for example, cited logistical difficulties as their greatest problem during the advance. The army had not adequately prepared their lines of communication prior to the offensive and had difficulty with supply in the battle area. Despite having a sufficient amount of ammunition in the theatre of operations, much of it had to be left behind as there was no way of moving it forward. There were ineffective arrangements for the evacuation and treatment of casualties because there were few forward dressing stations. The army also received requests for ammunition and food days late, and was equally slow in responding because rail and road links to the forward area had not been sufficiently planned or constructed. The offensive slowed as starving Germans looted British supply dumps and trench systems for food. ${ }^{225}$

Despite the initial successes of the German troops, the allied forces rallied and managed to hold the line, halting the German assault 10 miles short of Amiens. ${ }^{226}$ An extremely important railroad junction of north-south channel traffic, Amiens' loss would have effectively separated the British and French armies, forcing their retreat or envelopment. ${ }^{227}$ Despite Fifth Army's defeat, and in spite of other territorial gains won by the Germans, the war did not end. Ludendorff's efforts to achieve a breakthrough had

\footnotetext{
${ }^{225}$ Martin Kitchen, The German Offensives of 1918 (Charleston, SC: 2001), p. 94.

${ }^{226}$ Tim Travers, The Killing Ground: The British Army, the Western Front and the Emergence of Modern Warfare 1900-1918 (London: 1987), p. 220.

${ }^{227}$ Robert Asprey, The German High Command At War: Hindenburg and Ludendorff Conduct World War I (New York: 1991), p 376.; Dr. Tim Cook to author.
} 
failed, and the allied powers were determined to launch a counter-offensive.

In anticipation of the campaign season of 1918, and in light of changes occurring in the larger BEF at the time, the Canadian Corps underwent a series of organizational and structural adjustments. Not only did the Corps make changes to its fighting arms, it also needed to prepare its logistical services in anticipation of future battles and a renewed war of movement that would entail extensive reconstruction and transport work. The Corps had gained the reputation as a potent offensive weapon, but it had also established itself as a formidable logistical entity, capable of surmounting the tasks allotted to it at Passchendaele and Vimy. The Canadian Corps would be responsible for providing the striking power at the sharp end of battle during the last year of the war. The Corps would be further charged with constructing infrastructure that would maintain not only its own forward movement, but parts of the BEF as well.

One of the most significant changes that occurred in the Corps from a logistical standpoint involved the re-grouping of the Corps' mechanical transport. On 14 April 1918, the Canadian Corps Supply Column and the Canadian Corps Ammunition Park were amalgamated to form the Headquarters Canadian Corps MT Column. ${ }^{228}$ Administratively, all the columns were absorbed into the office of the Senior Mechanical Transport Officer (SMTO) to provide a headquarters for all of the Corps MT. ${ }^{229}$ The units were:

\footnotetext{
${ }^{228}$ Later, in July 1918, the Canadian Motor Machine Gun MT Company and the Canadian Engineer MT Company were formed.

${ }^{229}$ Arnold Warren, Wait for the Waggon, p. 110; The MT units were then organized as a Corps MT Column controlled by Headquarters Canadian Corps MT Column, which worked with the Senior Mechanical Transport Officer (SMTO).
} 
- Headquarters Canadian Corps MT Column

- Canadian Corps Troops MT Company

- $\quad 1^{\text {st }}$ Canadian Divisional MT Company

- $\quad 2^{\text {nd }}$ Canadian Divisional MT Company

- $\quad 3^{\text {rd }}$ Canadian Divisional MT Company

- $\quad 4^{\text {th }}$ Canadian Divisional MT Company

- Canadian Motor Machine Gun MT Company

- Canadian Engineer MT Company

The Corps contained three field ambulances of seven ambulances each. Furthermore, the horses and mechanical vehicles attached to the $5^{\text {th }}$ Divisional Artillery were retained so these guns could supply themselves. ${ }^{230}$ The four Divisional Mechanical Transport Companies, which were formed by amalgamating the Supply Column and Ammunition Sub-Park of each Division, drew the supplies and field ammunition required by their respective divisions. The Canadian Corps also had two additional MT units over and above their Imperial counterparts, which would give the armoured cars and engineers the transport they needed to move the petrol, ammunition, and engineering stores they required to complete their tasks. In July of 1918 , the Corps was authorized to add one Canadian Motor Machine Gun Mechanical Transport Company (CMMGMTCo) and one Canadian Engineer Mechanical Transport Company (CEMTCo). ${ }^{231}$

The CEMTCo, under the command of Major N.J. Lindsay, constituted the largest MT column in the Canadian Corps. This company transported stores and other building

\footnotetext{
${ }^{230}$ Neal Porter, "From Trench to Open Warfare: The State of Logistics in the Canadian Corps, August to November 1918", MA memoir, University of Ottawa, 1998, p. 15; "Transport", n.d., LAC RG 9, III D2, vol. 4810 , file "Miscellaneous Data". Hereafter Transport. The $5^{\text {th }}$ Division's transport was provided by 1 Company of the $5^{\text {th }}$ Divisional Train and the $5^{\text {th }}$ Divisional Artillery Mechanical Transport Detachment. Another unit, the Corps Troops Mechanical Transport Company, rationed the personnel and horses of formations in the Corps that did not form part of a division.

${ }^{231}$ Transport; Arnold Warren, Waiting for the Waggon, pp. 110-113.
} 
material for the Corps Engineers. ${ }^{232}$ The problem of transporting engineer stores under the former establishment was solved and it "was no longer necessary to beg, borrow or steal lorries from the MT column or horse transport from infantry brigades."233 The Canadian Corps, after it was reorganized in 1918, had 100 more lorries than its British counterpart. The Corps' extra complement of lorries would give it the ability to move more ammunition, stores and supplies, which would in turn render it more effective during the battles of 1918. This increased mobility would aid significantly in the crucial engineering work required during offensive operations and while pursuing the Germans in the final months of the war. This mobility would also facilitate the Corps' role as a mobile shock formation capable of moving quickly to new locations along the BEF's front.

Another important change that affected Corps logistics involved the engineers and pioneers. Currie and his staff had realized that the engineers were unable to perform their duties optimally without drawing strength from the infantry. Although infantry working parties were not entirely done away with, the 1918 re-organization aided the sappers' work immeasurably and allowed the infantry the opportunity to rest, refit, and train when they were out of the line rather than being employed as labourers. ${ }^{234}$ Canadian divisions

\footnotetext{
${ }^{232}$ Arnold Warren, Waiting for the Waggon, p. 114; Canadian Corps. G.S. Machine Gun File, Organization, p.6, 5 April 1919, LAC, RG 9, III D2, vol. 4797, file 86 ; DHist, "Narratives Covering Operations of the $1^{\text {st }}$ Canadian Independent Force, The Composite Brigade, and Brutinel's Brigade During 1918," (Ottawa: 1926), p. 11. The author would like to thank Dr. Tim Cook for providing this document from the Directorate of History and Heritage, DND. The CMMGMTCo that accompanied the Canadian Independent Force consisted of a number of lorries that provided water, supplies, ammunition and POL (petrol, oil and lubricants) for the unit.

${ }^{233}$ Colonel H.F.H. Hertzberg, "The Re-Organization of the Engineering Troops of a Canadian Division - Great War 1914-18", Canadian Defence Quarterly, p. 46.

${ }^{234}$ A.W. Currie, Canadian Corps Operations During the Year 1918-Interim Report (Ottawa: 1919) , p. 103. Hereafter Corps Operations.
} 
were given a brigade headquarters, a bridging transport unit, and three battalions of engineers. ${ }^{235}$ Because of the new organization, tasks were performed more quickly than under the old system as divisional sectors were divided and a battalion of engineers assigned to complete work in each area. The new organization also featured the bridging specialists of the Bridging Transport Unit (BTU). The BTU had enough pontoon bridging equipment for 225 feet of medium bridge, which would increase the mobility of the Canadian Corps when it needed to cross some of France's numerous waterways. Logistics within the Canadian Corps benefited greatly from the reorganization, and it is worth noting that "after a very thorough...investigation, ...the British authorities adopt[ed] the Canadian Corps System, with certain modifications, in their proposed establishments for Great Wars."236 The engineer re-organization guaranteed that the construction of logistical infrastructure in the Corps area could be speedily carried out, and would aid greatly not only in the battles of the 1918 , but during the pursuit of a rapidly retiring German army in the fall.

Changes also occurred in the units responsible for tramways in the Corps area. In December of 1917, Brig.-General Bethune Lindsay outlined the new establishment for the unit. ${ }^{237}$ Besides the nomenclature change, each company gained eighty-two additional

\footnotetext{
${ }^{235} \mathrm{~A}$ total of 118 officers, 2,995 other ranks, 526 horses, 24 lorries, 1 motor car, 3 box cars and other vehicles per division. Colonel H.F.H. Hertzberg, "The Re-Organization of the Engineering Troops of a Canadian Division - Great War 1914-18", p. 39; "Organisation and Records", 27 May 1918, LAC, RG 9, III C5, vol. 4448, folder 2, file 2. Each engineer battalion was divided into companies that were in turn arranged into two subsections with each sub-section being numbered 1 to 16 .

${ }^{236}$ Colonel H.F.H. Hertzberg, "The Re-Organization of the Engineering Troops of a Canadian Division - Great War 1914-18", p. 46.

${ }^{237}$ Brig.-General Bethune Lindsay to O.C., Canadian Corps Tramways, 9 December 1917, LAC, RG 9 , III C5, vol. 4447 folder 4, file 5, "Organization". Number 1 section, Canadian Corps Tramways Company,
} 
personnel. ${ }^{238}$ This would give even more manpower to an already effective organization, which would pay dividends during the last year of the war. The Corps would now have more manpower devoted to a mode of transportation that they were adept at constructing and operating. Increased proficiency in this area would not only allow Corps tramways to haul more ammunition and supplies, but it would free up other transportation modes to do other crucial logistical work.

Upon first glance, the infantry re-organization was undertaken with only tactical considerations in mind. However, even though the engineers had more manpower to draw from, the infantry's ranks were bolstered because Currie knew working parties could not be done away with entirely. As part of the 1918 re-organization, Currie increased the strength of his battalions by 100 men, which provided additional tactical striking power, but also provided more men to be drawn for logistical uses. ${ }^{239}$ Furthermore, a suggestion on 22 May 1918 that infantry battalions could give up their battalion pioneers, who were responsible for improving billets, beds, latrines and other duties in their unit's immediate area, was rebuked by Major-General Watson commander of the $4^{\text {th }}$ Canadian Division: "I am of the opinion that it is not in the interests of the Service to reduce the establishment of pioneers in an Infantry Battalion. These men are exceedingly useful in their

became No. 1 Tramway Company (Operating). Secondly, number 2 section of the Canadian Corps Tramway Company became No. 2 Tramway Company (Construction). These two units were considered to be distinct, but for the purposes of administration came under the jurisdiction of the C.R.E. Corps Troops.

${ }^{238}$ Captain Macphail to O.C. No. 2 Tramways Coy., 1 February 1918, LAC, RG 9, III C5, vol. 4447, folder 4, file 5; "Mobilization Tramways Coy C.E.", 30 May 1918, LAC, RG9, III C5, vol. 4445, folder 1, file 5. Establishment of a Canadian tramway company was: 20 officers, 1 warrant officer, 362 other ranks, 23 horses, 1 motor car, 1 box car, 6 motor cycles, 4 motor lorries, 1 G.S. wagon, 1 G.S. limber, and 1 water cart.

${ }^{239}$ Schreiber, Shock Army of the British Empire, p. 20. 
units...They are trained soldiers and can always be used as fighting personnel in an emergency....240

Along with the newly organized engineers and infantry, the Corps had a number of units that were devoted solely to labour tasks in the Corps area and were periodically engaged in work under BEF control. In April 1918, the Labour Commandant, Canadian Corps, who administered and commanded all labour in the Canadian Corps area, recommended that the two Canadian infantry works battalions be re-organized into a Canadian Works Group H.Q. and four Canadian infantry works companies. ${ }^{241}$ They were used to dig trenches, construct and maintain broad gauge and light railway lines, road making, cable laying, manning r.e. parks and handling ammunition. During the last year of the war these companies along with their headquarters worked on roads and tramways during the advance. The Canadian Corps also had four divisional employment companies, one for each division that provided extra labour for their respective divisions. The $5^{\text {th }}$ Canadian Area Employment Company (CAEC) moved with the Corps and undertook labour tasks in the Corps area. The $6^{\text {th }}, 7^{\text {th }}$, and $8^{\text {th }}$ CAECs were assigned tasks in the Corps area that involved Area Commandants, Town Majors, Laundries and Canteens. The $9^{\text {th }}$ CAEC worked primarily with the Y.M.C.A. and moved with the Corps as well. There was a Labour Reinforcement Pool to keep these units up to strength. ${ }^{242}$

\footnotetext{
${ }^{240}$ Major-General D.Watson to Canadian Corps 'Q', 30 May 1918, LAC, RG 9, III C1, vol. 3893, folder 55, file 19, "Economy".

241،"Report Covering Labour Canadian Corps Year-1918", 28 January 1919, p. 1, LAC, RG 9 III C6, vol. 4449, folder 1, file 1, "Cdn. Labour Group "Administration"(Labour)".

${ }^{242}$ “General Report Covering the Work of Labour with Canadian Corps in France”, 28 January 1919, p. 6. LAC, RG 9, III C6, vol. 4449, folder 1, file 1 "Cdn. Labour Group "Administration (Labour)".
} 
While seemingly mundane, the reorganization of the logistical services of the Canadian Corps would pay dividends in the coming battles of the last Hundred Days. Not only would the engineers, mechanical and horse transport, and labour support the CC's set-piece battles, but the Corps was now adequately outfitted with a more balanced logistical system to pursue a retreating German army in the coming months. One of the most pressing logistical considerations of the war had been solved with the new organization: the Corps now had the labour and mechanical transport resources it needed for the seemingly endless array of infrastructure construction and supply tasks required by a Corps that was considered to be an elite fighting force. The combined logistics system, although still subject to the forces of friction, would be able to prepare for the battles of the last Hundred Days. Just like the fighting arms, it was incumbent upon commanders to insure that their logistical services were robust, flexible forces that could meet the demands and solve the difficulties of the friction of war.

On 20 July 1918, at a conference at Fourth Army headquarters, Currie was informed that the Commander-in-Chief of the BEF had proposed a plan that would involve the Canadian Corps, in an attack designed to push the Germans back from the logistically vital Amiens-Paris railway. ${ }^{243}$ During the March Offensive, there was anxiety that the Germans aimed not only to separate the British and French Armies, but also be able to disrupt the extremely important railway centres of Amiens and Abancourt. The disruption of the railways at these two places along the BEF's southern line of communication would endanger the Armies in the north as their source of ammunition

\footnotetext{
${ }^{243}$ Currie, Corps Operations, p. 127.
} 
and supply would be cut off. ${ }^{244}$ The Germans had advanced within ten miles of Amiens during the offensive and could harass the rail lines with heavy guns. The Canadian, Australian, British and French attack in the Amiens sector on 8 August 1918 would help ease the pressure on the logistical hub and guarantee that the BEF's essential southern line of communication was no longer threatened.

The logistical movement of the Canadian Corps to a new sector needed to be performed clandestinely in order to conceal the area of attack. This was due in large part to the reputation of the Canadians as shock troops: any indication that they were in the line would likely alert the enemy to a forthcoming attack. In the interest of maintaining this secrecy, which would in turn translate to tactical and operational surprise on zero day, Currie was encouraged to plan for the capture of Orange Hill in an effort to "deceive everybody" including members of his staff. Only the Brigadier-General, General Staff (BGGS) N.W. Webber, the General Officer Commanding Royal Artillery (GOCRA) E.W.B Morrison and the Counter Battery Staff Officer (CBSO) A.G.L. McNaughton were informed of the Amiens plan and sent to reconnoitre the Canadian Corps' front of attack. $^{245}$

The impression given to H.E.Burstall, commander of the $2^{\text {nd }}$ Canadian Division, was that his division would be used in an operation in the Ypres area. The illusion was enhanced when Burstall and his GSO1 visited the Ypres sector and plans were discussed

\footnotetext{
${ }^{244}$ Sir Henry Rawlinson to Sir Henry Wilson, quoted in Ian M. Brown, "Feeding Victory: The Logistic Imperative Behind the Hundred Days," in Peter Dennis and Jeffrey Grey, (eds.), 1918: Defining Victory (Canberra: 1999), p. 137-138.

${ }^{245}$ Currie, Corps Operations p. 128.
} 
to attack in that area. Furthermore, on 28 July "one Battalion, $\left(27^{\text {th }}\right.$ Battalion, $6^{\text {th }}$ Canadian Inf. Brigade), was ordered to move North by strategical train, to come under the orders of the X Corps, ${ }^{246}$ in order to carry out the ruse.

Like Currie, commanders were under orders to take steps to keep the scope and date of the operation secret and "any officer, NCO or man discussing the operation in public...[would] be severely dealt with." ${ }^{247}$ While this was important to achieve surprise, it had a negative impact on logistical planning. All troop and transport movements were to occur at night except in extreme circumstances. Men that were billeted or bivouacked near the front were to restrict their movements during daylight hours as a precaution against being detected by enemy aerial observers. Each division was also responsible for providing police to ensure that these rules governing movement were enforced.

Furthermore, the RAF's officer commanding arranged aeroplanes to observe and report any prohibited activity. ${ }^{248}$ The secrecy of the move was designed to reduce friction on the attacking troops on zero day, but ironically the exact opposite occurred for the logistical staff, which had so little time to plan the move. While friction was reduced in one area (by achieving surprise), it was increased exponentially for the Corps logistical staff and services. The prospect of moving 100,000 men, countless horses, artillery, ammunition,

\footnotetext{
${ }^{246}$ H.E. Burstall,"2nd Canadian Division. Report on Operations Carried Out During Period $13^{\text {th }}$ March, 1918 to $11^{\text {th }}$ November, 1918.", Battle of Amiens, nd., p. 5, LAC, RG 9, III D2, vol. 4794, file 54, " $2^{\text {nd }}$ Canadian Division Narrative of Operations From March $13^{\text {th }}$ to Nov $11^{\text {th }} 1918$,". Hereafter " 2 nd Canadian Division Report, 1918."

${ }^{247}$ War Diary Canadian Corps G.S., "L.C. Instructions No. 1.", Part 3(b), p. 2, LAC, RG 9, III, D2, vol 4789, file 2. Hereafter L.C. No. 1. "L.C." stood for Llandovery Castle, a Canadian hospital ship sunk in June 1918.
}

${ }^{248}$ L.C. No. 1., Part 3 (c) (i, ii, iii), p. 2; L.C. No. 1., Part 3 (d), p. 2. 
supplies, and setting up an exhausting range of details, including march tables and transport arrangements, at such short notice was a daunting task. To put the situation into perspective, it was the equivalent of moving the entire population of Kingston along with their belongings, animals and shelter, with one day's notice, to Belleville.

Because of the need for secrecy, the orders to move south to the Amiens sector were withheld from the office of the SMTO until the day before the Corps embarked, and when revealed, staff officers were forced into a frenzy of work. Before their departure, the SMTO ensured that all of the MT companies travelled with a full load of ammunition in order to begin the ammunition dumping program shortly after arriving in the new area. Subsequently, as was customary before any move, the SMTO placed each MT company under the control of its respective division. Meanwhile, the Canadian Engineers MT Co. managed to move the Corps headquarters eighty miles in the span of one day, and helped to situate it behind Amiens. ${ }^{249}$

On $28 \mathrm{July}$, the $2^{\text {nd }}$ Canadian Division was issued orders to travel south, and began its move the following day. The $4^{\text {th }}$ and $6^{\text {th }}$ Canadian Brigades and divisional engineers were moved by tactical train, the $5^{\text {th }}$ Canadian Infantry Brigade moved by buses, and the divisional artillery by march route. The need for stealth and secrecy, and the hot weather, made the move an uncomfortable one, but the $2^{\text {nd }}$ Division managed to complete it by 31 July. ${ }^{250}$ The majority of the artillery marched secretly from Arras to Amiens in darkness,

\footnotetext{
${ }^{249}$ Major S.D. Lawson, "Report of the Work of the Canadian Corps Mechanical Transport During the Last 100 days of the European War", Amiens Battle, 19 September 1919, p.1, LAC, RG 9, III D2, vol. 4810, file "“CASC' Titled Notes on Last 100 Days by Major S.D. Lawson". Hereafter: "MT During the Last 100 days."

${ }^{250}$ “ $2{ }^{\text {nd }}$ Canadian Division Report, 1918.", p. 5.
} 
and rested during daylight hours. Meanwhile, other guns were moved by train. The first of 646 guns arrived in the Amiens area on 31 July and took up their positions, all of which were to be supplied with 400 to 600 rounds of ammunition. ${ }^{251}$ By executing the move of their headquarters and MT units in such short notice, and under a veil of secrecy, the Canadian logisticians showed how adept they had become. The robust logistics system would be able to function with its MT component in place when the Corps arrived in the Amiens area.

The $3^{\text {rd }}$ Division took part in the Corps' sleight of hand to the north as it moved one battalion (the $4^{\text {th }}$ CMRs) to Second Army in Belgium. The rest of the division, meanwhile, headed south in early August with the divisional artillery and transport marching the distance. The rest of the division moved either by bus, rail, or march route to their concentration areas in darkness. Upon arrival in the Amiens sector, the many wooded areas were able to effectively conceal the division's personnel. ${ }^{252}$ The work on behalf of the Corps' logistical staff, despite the difficulties, not only moved the divisions clandestinely, but would also enable the Corps to set up its combined logistics system for the coming battle.

The administrative efforts to organize these moves have often been overlooked by historians. Furthermore, the exertions required on behalf of the average soldier to undertake these journeys has also been given short shrift. Victor Wheeler described the

\footnotetext{
${ }^{251}$ E.W.B. Morrison, "Operations of Canadian Corps Artillery In the Field For Year 1918.", nd., p. 2., LAC, RG 9, III C1, vol. 3893, folders 56, file 4.

${ }^{252}$ L.J. Lipsett, " $3{ }^{\text {rd }}$ Canadian Division. Report on Operations from Aug. $8^{\text {th }}$ to Aug. 16 th", 17 August 1919 p. 1, LAC, RG 9, III D2, vol. 4795, file 63, "Narrative of Operations Amiens $8^{\text {th }}$ August to $16^{\text {th }}$ August 1918. 3 Div.".
} 
$50^{\text {th }}$ Battalion's move to the Amiens sector:

Our mode of transportation was variously by buses, railway boxcars, flatcars, lorries, limbers, bicycles and vehicles of every description, but most of the distance was covered afoot. The allnight [sic] march from Wanel and Sorel...merited 'special attention' in the Battalion Diary for 4 August... [the] Men's magnificent behaviour under great physical and mental strain when on extraordinarily difficult marches was one of the indelible sagas of the war. ${ }^{253}$

The strain of such route marches was telling, and soldiers were often afforded some time to recover from their arduous slogs after they reached their concentration area. The various vehicles mentioned by Wheeler were employed to lessen the distance the Corps' units had to march, and it must be noted that staff planners had, certainly by 1918 , realized the importance of transporting troops by rail and bus in order not to exhaust them.

Even though the preservation of secrecy prior to operations had been a consideration early in the war, ${ }^{254}$ the move to the Amiens sector in July and August of 1918 and the subsequent build-up for the battle, constituted one of the most successful uses of surprise during the war. Though some Germans expressed anxiety over the amount of activity in the lines opposite them prior to the battle, many prisoners later admitted that the attack was completely unexpected. ${ }^{255}$

The need for secrecy prior to the operation caused problems for the Canadian Corps' 'Q' staff. There was legitimate reason for complaint by Lieutenant-Colonel W.B.

\footnotetext{
${ }^{253}$ Victor W. Wheeler, The $50^{\text {th }}$ Battalion In No Man's Land, p. 230.

254“Preservation of Secrecy”, 13 June 1916, LAC, RG 9, III C1, vol. 3889, folder 45, file 2, “Secrecy”.

${ }^{255}$ S.F. Wise, "The Black Day of the German Army: Australians and Canadian at Amiens, August 1918," in Peter Dennis and Jeffrey Grey, (eds.), 1918: Defining Victory (Canberra: 1999), p. 23.
} 
Anderson, Assistant Quartermaster General (AQMG), Canadian Corps, ${ }^{256}$ who felt that the staff officers responsible for the Corps' move should have been informed earlier than they were. Although the strict enforcement of secrecy aided the operation, Anderson felt that certain problems could have been avoided had the administrative staff officers been given adequate time to prepare. He stated that "it was only by chance and good luck that trench munitions were obtained and issued to the $3^{\text {rd }}$ Canadian Division on the night of the $7^{\text {th }} \ldots$ the original trench munitions originally consigned to them went astray." ${ }^{\text {,257 }}$ If $Q$ staff had known of the operation in good time, arrangements for ammunition refilling points, trench munition dumps, medical arrangements, battle equipment, reserve supplies, watering of horses and the full range of logistical details so integral to any successful offensive operation could have been mounted with less strain on the staff. Anderson also pointed out that staff officers were far less likely to commit a breach in secrecy than were the numerous horses being led three times a day to watering points prior to the battle. ${ }^{258}$ Although there were logistical problems that occurred because of the short notice given to the Corps' staff, Q staff still managed to orchestrate the move and provide the support necessary for the operation to occur. According to one report, the "whole of the operation was essentially an administrative operation until the troops reached the assembly area on the $6^{\text {th }}$ and $7^{\text {th }}$ August. ${ }^{9259}$

${ }^{256}$ Various, Report of the Ministry, p. 315.

${ }^{257}$ “Notes On Amiens Operations. Canadian Corps 'Q"', Part 4, 14 September 1918, p. 3, LAC, RG 9, III, D2, vol. 4789, File "Administrative Arrangements Amiens.". Hereafter "Canadian Corps 'Q' Amiens."

258“Canadian Corps 'Q' Amiens”, Part 4.

${ }^{259}$ " 1 st Canadian Division Report on Administrative Arrangements for Operations East Of Amiens, August $8^{\text {th }}$ to $22^{\text {nd }}$, 1918", Administrative Staff Officers, nd, p. 47, LAC, MG 30, E54, F.R. Phelan Papers, 
Prior to the battle, many logistical aspects of the operation were laid down in $L-C$ Instructions No. 2. Before zero hour on 8 August, the $1^{\text {st }}, 2^{\text {nd }}$ and $3^{\text {rd }}$ Canadian Divisions were responsible for improving roads and tracks in their respective areas. Work was to be "done gradually so as not to attract attention" and all newly constructed signboards were to be camouflaged. ${ }^{260}$ Parties of engineers were assigned specific routes to work on after the battle began, and a priority was set to "get communication across No Man's Land at the earliest possible moment to enable the Field Artillery to get forward." ${ }^{, 261}$ In order to avoid traffic problems after zero hour, the $1^{\text {st }}, 2^{\text {nd }}$ and $3^{\text {rd }}$ Divisions were all restricted to the roads and tracks in their areas, and the $4^{\text {th }}$ Canadian Division, in reserve, was to use any convenient roads and tracks when its units needed to move. ${ }^{262}$ Despite the effort to relegate traffic to specific routes, traffic control and road congestion remained a problem during the buildup for the operation.

These problems were offset through traffic control initiatives, an issue closely related to the supply of artillery and troops as well as reliefs when different formations moved into the line. There was significant congestion as more than 300,000 men, from four national forces, tried to fit into the area. This necessitated the organization of traffic control. Under normal circumstances, it was essential to designate a strong force of traffic police to be placed in charge of all roads and routes in the concentration area and

vol. 1, file "Operations 1915,1918". Hereafter " 1 st Division Administrative Report Amiens".

${ }^{260}$ “L.C. Instructions No. 2.”, Part 8(a) (i, ii), LAC, RG 9, III, D2, vol 4789, file 2 “War Diary Canadian Corps G.S.". Hereafter L.C. No. 2.

${ }^{261}$ L.C. No. 2. Part 8(a) (iii).

${ }^{262}$ L.C. No. 2. Part 8(a) (iv). The $3^{\text {rd }}$ Division was relegated to Roye Road and Track "A"; The $1^{\text {st }}$ Division to Valley Road and Tracks " $B$ " and "C"; The $2^{\text {nd }}$ Division to Railway Road, Tracks " $D$ " and "E". 
the front of attack some days before the arrival of the assault troops. However, the arrival of the Canadian forces just three days prior to the attack made the establishment of traffic control priorities more pressing. A considerable number of officers were normally detailed to assist the work of the traffic police, particularly at congested corners. After the commencement of the operation, troops and ammunition had to push rapidly forward, which created an immense volume of traffic that required rigid control in order to avoid slowdowns and confusion. To ensure the efficiency of traffic control, telephone communications from important traffic points to the APM (Assistant Provost Marshal) and also to Corps headquarters was carried out. All of the artillery routes, roads for MT, and tracks for pack animals required regulation. ${ }^{263}$ Traffic control prior to and during operations was as difficult as "the control of traffic in a large city, apart from the hostile harassing fire which is liable to upset all traffic at any minute."264

The Quartermaster's branch was responsible for the maintenance and construction of roads (outside the forward area and not under the jurisdiction of the $\mathrm{CE}$ ), for the allotment of roads to different types of vehicles, and for the control of the speed and direction of traffic utilizing these roads. The construction and maintenance of these roads was carried out through the DAD Roads (Deputy Assistant Director of Roads), who was responsible for construction and maintenance of roads outside the forward area; for

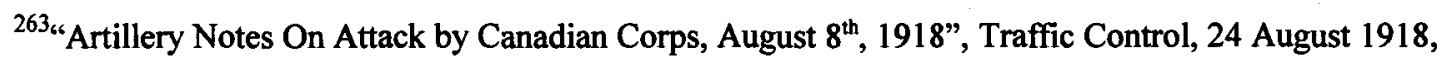
pp. 1-2, LAC, MG 30, E81, E.W.B. Morrison Papers, vol 2, file "Artillery Corps: Orders and Instructions 1917-Oct 1918."

${ }^{264}$ Various, Report of the Ministry, p. 323, 218. 
this purpose, he was in close liaison with the Labor Commandant at all times. ${ }^{265}$ After the battle, it was emphasized by Anderson that horse transport and troops should be trained to use dry weather tracks, especially those alongside main roads, to ease congestion of the main thoroughfares, and that these tracks should be well marked with signboards. ${ }^{266}$ This logistical consideration was extremely important, especially prior to and during the Amiens battle, and required constant vigilance by the APM's personnel to keep traffic running efficiently.

The mechanical transport travelled on these congested roads in order to deliver ammunition and supplies to the different formations in the Corps prior to the operation. The prospect of providing adequate artillery ammunition and other supplies and equipment was a difficult one, which put pressure on the new organization of the Canadian Corps's MT. Lieutenant-Colonel Sutherland Brown, AA and QMG of the $1^{\text {st }}$ Canadian Division, criticised the new MT organization under the SMTO, but was too heavy handed in his assessment, even though the new establishment was suffering from growing pains. Sutherland Brown stated that "the system whereby the SMTO retains control of the Divisional MT Coy, especially during operations, is wrong in principle and in practice. It undoubtedly should function for its Division, which is more conversant with its own supply and ammunition difficulties than is the SMTO, when operations are in progress." Communications between the $1^{\text {st }}$ Division and its MT company were not maintained for several days prior to the operation because "the Signal communication

\footnotetext{
${ }^{265}$ Ibid, p 218.

${ }^{266}$ “Canadian Corps 'Q' Amiens”, Traffic, p. 4.
} 
with the Corps was vary bad at times. ${ }^{2067}$ However, Brown failed to take into account the difficulties that had occurred outside of the SMTO's, the $1^{\text {st }}$ Division's and even the Canadian Corps' jurisdiction.

The logistical problems in dumping sufficient ammunition occurred in part because of the erratic arrival times of broad-gauge ammunition trains at the Corps' railheads. Major J.D. Lawson, the SMTO, stated that the foremost priority for him and the MT of the Corps was to establish sufficient heavy artillery ammunition stockpiles for the opening of the assault on zero day, and this problem was amplified not only because of time constraints, but because of the inability of BEF ammunition trains to arrive at specified times:

Ammunition trains were slow in arriving, and added to this was the great distance of the Ammunition Refilling Points from Railhead. It became a case of fighting against time, and two days before the battle commenced it was found that only about half the ammunition required had been placed at the guns. The cause of this was not the lack of transport or the service that was rendered by the lorries, but the supply. ${ }^{268}$

To ensure the guns had enough ammunition to destroy enemy positions and protect their advancing infantry, lorries were needed to dump their reserve ammunition, which was normally carried in case of an emergency, and to haul shells from army dumps. ${ }^{269}$ Time was a factor: there were only three and a half days in which to dump 2,000 tons of ammunition at forward battle positions each night between the arrival of the field and heavy brigades and zero hour. This entailed a journey of 7 to 9 miles for heavy artillery

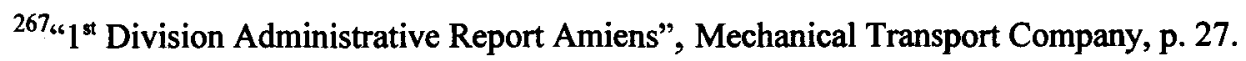

${ }^{268}$ Major S.D. Lawson, "MT During the Last 100 days." p.2. Emphasis added.

${ }^{269}$ Ibid.
} 
and from 4 to 6 miles for field artillery from forward dumps to battery positions. ${ }^{270}$ It was a gruelling schedule, and Currie's insistence that his transport drivers remained category ' $A$ ' men had paid off as they had the physical endurance to keep up with the frenetic pace needed to supply ammunition, petrol and supplies to the Corps during the crucial build-up period prior to offensive operations. ${ }^{271}$

The shroud of secrecy affected parts of the BEF, and without adequate time to prepare, there was a "great shortage of petrol in [the] Fourth Army, [and] many lorries [were] idle owing to this. ${ }^{\text {272 }}$ Despite numerous lorries that were assigned to haul ammunition being immobilized, the MT adapted to this situation by hauling petrol from Abbeville, which was far away. ${ }^{273}$ While secrecy provided an advantage for attacking troops during the battle, it caused friction logistically as staff were unable to make all the necessary preparations in time for 8 August. Not only was the logistical staff of the Corps affected, but so was the Fourth Army. The temporary petrol shortage experienced by the Canadian Corps meant that lorry drivers had to scramble in order to meet the artillery's ammunition requirements. They achieved this, but the last delivery of shells occurred only hours before the battle commenced. ${ }^{274}$ The combined logistics system was flexible

\footnotetext{
270“Artillery - Amiens,” Difficulties In Dumping Ammunition, nd, LAC, RG 9, III, D3, vol. 4807, file 175.

${ }^{271}$ James McWilliams and R. James Steel, Amiens Dawn Of Victory (Toronto: 2001) pp. 32-33.; Generally, medical categories were: Category A: Fit for General Service; Category B: Not fit for General service, but fit for certain types of service overseas; Category D: Temporarily unfit.; Category E: Unfit for service. Awaiting discharge. For more on Categories see: Various, Report of the Ministry, pp. 40-41.

${ }^{272}$ War Diary, $1^{\text {st }}$ Canadian Division Administrative Branches of the Staff, 5 August 1918, LAC, RG 9, III D3, vol. 4840, microfilm, reel T-1923, file 93.

273“'Canadian Corps 'Q' Amiens,” Mechanical Transport, p. 3.

274“Canadian Corps 'Q' Amiens," Ammunition, p. 1.
} 
enough to enable the Corps to counter these obstacles, but not without the dedication of lorry drivers.

Along with roads and tracks, the maintenance and repair of bridges was to be crucial in the $3^{\text {rd }}$ and $1^{\text {st }}$ Divisional sectors after the attack was underway. Engineers, along with their equipment, were assigned to work on bridges "as soon as the locality ha[d] been cleared of the enemy."275 The greatest number of engineers was employed on infrastructure construction as they repaired roads, ensured water supply, and repaired light railways and tramways under the direction of the CE, Canadian Corps. ${ }^{276}$

Prior to the attack, a scheme outlining movement priorities after zero hour was distributed. In addition to the fighting arms, the logistical services received instructions regarding how they should proceed. Each of the divisional areas were allocated bridges that were to be used during the advance. All lorries and ambulances that were driving to rear areas were to use separate roads in order not to interfere with the forward movements of other vehicles. Transport assigned to brigades that were detailed for the furthest objectives were to cross first. This transport was to cross in the following order: ' $A$ ' Echelon of first line transport, which included Lewis gun limbers, s.a.a. and tool wagons, water carts, and medical carts, were to cross first. Secondly, transport from engineer battalions and machine gun companies were to move over the bridges. ${ }^{277}$ Behind these

\footnotetext{
${ }^{275}$ L.C. No. 2. Part 8(b) p. 3. After the attack was underway, $3^{\text {rd }} \mathrm{Cdn}$. Division was responsible for the repair and maintenance of the Domart, Hangard, and Demuin bridges. $1^{\text {st }} \mathrm{Cdn}$. Div. Was responsible for the Aubercourt-Courcelles, Ignaucourt, and Cayeux bridges.

276 “" $2^{\text {nd }}$ Canadian Division Report, 1918.", p. 8.

${ }^{277}$ L.C. No. 5 , Part 21, (b) (i). p. 4.
} 
vehicles, limbers and teams with the $4^{\text {th }}$ Division's artillery were to cross, followed by DACs, then 'B' Echelon of the first line transport, which included cookers and mess carts, would proceed by brigade groups, and finally divisional train vehicles, which would wait until they received orders from Canadian Corps ' $Q$ ' staff before proceeding. ${ }^{278}$ These instructions regarding the forward movement of transport after zero were in anticipation of a lengthy advance by the assault troops. The supplies and ammunition that they carried would aid ongoing operations and help to consolidate the newly won ground. Transport arrangements were meticulously planned, an example of the importance that staff placed on supply issues during the attack.

The exhaustive preparations for the battle and the emphasis on secrecy paid off on 8 August. Not only had the combined logistics system managed to provide the supplies and ammunition required for the first hours of the action, contingencies had been made for an advance deep into enemy territory. At 4:20 AM, an intense artillery barrage opened up, without a round fired previously for registration, signalling the beginning of the attack. It was followed instantly by the forward movement of tanks and infantry. ${ }^{279}$ The artillery barrage had a reduced high explosive content in order to keep shell craters to a minimum, and to make the way more passable to tanks and vehicles during the advance. ${ }^{280}$ The logistical requirements supported and constrained what the attacking

\footnotetext{
${ }^{278}$ L.C. No. 5, Part 21, (b) (ii, iii, iv). p. 4.

${ }^{279}$ Sydney F. Wise, “Amiens, August 1918: A Glimpse of the Future?"in Briton C. Busch, ed., Canada and the Great War. Western Front Association Papers, (Kingston: 2003), p. 180.

${ }^{280}$ “Artillery Notes On Attack by Canadian Corps, August 8", 1918", Notes on Barrage, 24 August 1918, p. 3, LAC, MG 30 E81, E.W.B. Morrison Papers, vol 2, file: "Artillery Corps: Orders and Instructions 1917-Oct 1918."
} 
arms could do in battle.

In the opening phases of the battle, the $6^{\text {th }}$ Field Battalion of Canadian Engineers filled trenches, built tank ramps, installed pontoon bridges to help infantry cross the Luce river on the $2^{\text {nd }}$ Division's front. While under fire, they graded tracks for cavalry, supply tanks, and transport that would be making their way forward. One crew constructed a water wheel on the river Luce to fill troughs for horses and mules. ${ }^{281}$ Parties of engineers were also attached to each infantry brigade to investigate dugouts, repair roads and construct light railways or tramways under the direction of the $\mathrm{CE} .^{282}$

Infantryman Will Bird had to cross one of the engineer-built bridges on 8 August: "There was a thick mist ..., but someone had foreseen such a difficulty and there was a strand of wire strung...from the trenches to the bridges. We could not hurry in the least, as the pontoon bridge was swaying under the tread of those crossing. Some shells landed with great splashes in the river...Our platoon made it without a hitch. ${ }^{, 283}$ Infantry were made to cross these bridges while sturdier ones were reserved for heavy vehicles. The combined logistics system directly affected the forward movement of elements of the fighting arms during active operations.

In addition to the tanks that would support the infantry, there were a number of supply tanks that carried out a logistical role during the battle. Four battalions of Mark V tanks, including a company of Mark IV tanks used for supplying ammunition and

\footnotetext{
${ }^{281}$ Sydney F. Wise, “Amiens, August 1918: A Glimpse of the Future?”, p. 180-181.

282 “2 $2^{\text {nd }}$ Canadian Division Report, 1918.", p. 5.

${ }^{283}$ Will R. Bird, Ghosts Have Warm Hands, p. 97.
} 
equipment, were to accompany the assault on 8 August. Two evenings prior to the attack, the tanks proceeded under cover of darkness to their laying up positions, where they waited throughout the day. On the night of the assault, they were to move up to their start line. In an attempt to conceal their movements, the $5^{\text {th }}$ Brigade RAF flew over the area "with a view to drowning the noise from the Tank engines." ${ }^{\text {284 }}$ The combined logistics system was being supplemented in this battle with these land-ships being used in a resupply role.

Although the supply tanks would receive mixed reviews, the use of tanks as a logistical vehicle showed the importance of logistics during an offensive operation and displayed the Canadians' willingness to experiment with new logistical techniques. Horses or mules were vulnerable to artillery fire, and because of high losses to the Corps' horses in 1917 , it was deemed necessary to replace them, at least in part, by another form of transport less vulnerable to enemy interdiction efforts. Sutherland Brown, AA \& QMG of $1^{\text {st }}$ Division, stated that "the main object was accomplished [by the supply tanks] inasmuch as a certain amount of ammunition and supplies were forwarded without having to use animals." In future operations, however, Brown pointed out that oil and petrol should have been available at the supply tanks' jumping off positions so they could be refuelled before the battle commenced. He also remarked that Mark V supply tanks would have been more efficient, and that the tanks should, in future, stay in open country. ${ }^{285}$ The older Mark IV tanks were only able to manage $1 \mathrm{mph}$, and had difficulty fulfilling their

\footnotetext{
${ }^{284}$ L.C. No. 3. Part 7 (e,f,g,h) p. .3.

${ }^{285}$ “ $11^{\text {st }}$ Division Administrative Report Amiens”, Supply Tanks, p. 19.
} 
role. One engineer described the venture as "completely useless." ${ }^{286}$ Despite their problems, the use of the tank in a resupply roll was sound in theory and would be put into practise in the Second World War. The experiment highlighted the importance of logistics during the advance and the willingness on behalf of the Canadian Corps to supplement the combined logistics system by other means.

Although many of the supply tanks had broken down, other efforts were made to supply the infantry during the battle. The combined logistics system would be further supplemented by the RAF. In addition to their duties of strafing enemy troops and strongpoints, they also dropped ammunition for advancing infantry during the battle. ${ }^{287}$ Furthermore, the RAF communicated via wireless or through information drop stations the amount of ammunition at positions occupied by the artillery accompanying infantry in a close support role. ${ }^{288}$

The depth reached by the attack presented problems for the MT of the Corps: they worked feverishly to help the DACs to establish new ammunition refilling points (ARPs, also know as dumps). To compound matters, the MT had to clear ammunition from the broad-gauge railheads that were arriving on trains several times daily. Feeding the troops presented more problems as pack trains often arrived forty-eight hours late, and new

\footnotetext{
${ }^{286}$ Quoted in Dean Chappelle, "The Canadian Attack at Amiens, 8-11 August 1918" Canadian Military History, vol 2, no. 2.(April, 1993), p. 94.

${ }^{287}$ S.F. Wise, Canadian Airmen and the First World War (Volume 1 of the Official History of the Royal Canadian Air Force) (Toronto:1981), Chapter 17, 'Amiens', pp. 518-541; Gregory Blaxland, Amiens: 1918, (London: 1968), p. 149.

288“"Artillery Notes On Attack by Canadian Corps, August $8^{\text {th }}, 1918$ ”, Communications, 24 August 1918, LAC, MG 30 E81, , E.W.B. Morrison Papers, vol 2, file: "Artillery Corps: Orders and Instructions 1917Oct 1918."
} 
supply refilling points (SRPs) had to be designated. ${ }^{289}$

The Canadian Corps' advance on 8 August of eight miles was extremely successful when compared to other first day gains during the war on the Western Front. For logisticians and the services at their disposal, an advance presents difficulties over and above the efforts of the enemy to interdict logistics. In the case of Amiens, the very act of advancing while expending vast quantities of ammunition, POL, and other resources put a strain on the Corps' logistical system as lorry drivers and horse transport scrambled to establish new ammunition dumps, keep in touch with the advancing arms, and clear commodities from the Corps' railheads. However, the combined logistics system had been designed in order to combat the friction generated by the forward movement of the Corps, and enabled the logistical services to allot resources where the fighting arms needed them most. The combined logistics system had evolved in order to render all possible support to the fighting arms, not only prior to, but during an advance: bridges were constructed, and ammunition and supply dumps were moved, along with hundreds of other details including efforts to consolidate newly won territory. Although great strain was placed on Q staff, it managed not only to move the Corps into an attack position clandestinely, but it overcame through flexibility, the friction associated with operating under that shroud of secrecy and was able to supply the materiel and transport necessary for a stunning victory.

After the attack in the Amiens sector ground to a halt because of increased

\footnotetext{
${ }^{289}$ Major S.D. Lawson, "MT During the Last 100 days," pp. 2-3; For a list of daily SRP and ARP locations from 17 July 1918 to 16 November 1918 see Untitled, n.d, LAC, RG 9, III D2, vol. 4810, file "Supply Railheads, TM dumps, etc."
} 
German resistance and a need to consolidate what had been gained, the Canadian Corps was again required for offensive operations. Haig decided to change the axis of the BEF's attack, something he could not have done so easily in 1916 without the subsequent improvements to his logistic system. The Canadians were moved back to First Army to attack in the Arras sector. ${ }^{290}$ The $2^{\text {nd }}$ and $3^{\text {rd }}$ Canadian Divisions were moved by tactical train and bus to the Bouquemaison area and in the next few days both units relieved Imperial Divisions in preparation for their attack on the German Hindenburg defence system. Other units would follow. ${ }^{291}$

The assault on the Hindenburg defences, including the Drocourt-Quent line, from the end of August to mid-October, featured the set-piece attack, and the logistical preparations did not differ from previous battles. After the Canadian Corps had fought through the heavily fortified defensive lines, it expanded the area's tramway network. Since the first years of the conflict, Canadians had made extensive use of tramways and, earlier in the year, authorities had stated that any narrow-gauge railways made and operated by the Canadian Corps would be "over and above the normal allotment to the Army of which the Corps formed part."292 Despite the official BEF policy that emphasized the pushing of standard gauge lines forward during the advance, the extension of the Canadian tramway system was sanctioned in September 1918 because the country between the Arras-Douai and Boisleux-Marquion lines was not well served

${ }^{290}$ Ian M. Brown, British Logistics on the Western Front, p. 197.

${ }^{291}$ Currie, Corps Operations, p. 142; "Report On Move To Arras Area and Operations From $26^{\text {th }}$ to $29^{\text {th }}$ August 1918”,n.d. LAC, RG 9, III D2, vol. 4810, file “A\&Q Arras. $19183^{\text {rd }}$ Cdn Div 26-29 Aug. 1918."

${ }^{292}$ A.M. Henniker, Transportation On the Western Front, 1914-1918, p. 453. 
by standard gauge railways. The reorganization of the Canadian Corps' engineers and labour pool, in addition to having two specialized tramway companies, meant that the Corps alone was able to provide the expertise and necessary manpower to construct these narrow-gauge lines. As a result, six light railway and tramway lines were pushed forward during September, which would aid logistics of not only the Corps, but also of First Army. Later, in October, an "extensive system was reopened to the west and north of Cambrai. At the end of October, railheads were as far east as Lourches and Denain."293 Not only was the Canadian Corps adept at providing for its own logistics after an advance, but it was also aiding greatly the progress of the army that commanded it during the last Hundred Days. The Canadian Corps was a formation that, from a logistical standpoint, punched far above its weight.

The grinding frontal assaults during the battle of Arras succeeded, albeit at a high cost in lives, and the Canadian Corps halted in front of the Canal du Nord on 4 September 1918 to allow for its logistical services and the rest of the BEF to move up. ${ }^{294}$ The main task for the Corps during the operation that would carry them over the Canal to the east was to form a defensive flank in support of troops operating further south, which required the capture of the heavily fortified Bourlon Wood and the high ground to the north. ${ }^{295}$ The second phase aimed to capture the crossings over the Canal de L'Escaut north-east of Cambrai in addition to taking the high ground over the Sensee valley between the Canal

${ }^{293}$ Ibid.

${ }^{294}$ Schreiber, Shock Army of the British Empire, p. 87.

295“B.W. Instructions No. 1”, Part 2, 19 September 1918, LAC, RG 9, III D2, vol 4794, file 52. Hereafter B.W. No.1. 
De L'Escaut and the Canal Du Nord. ${ }^{296}$

The canal, and the flooded ground that on each side, presented the Canadians with a tactical and logistical obstacle. In order to successfully continue to assault after the canal was crossed, logistical support would feature heavily in the opening phases. The logistical arrangements for the attack on the Canal du Nord would take full advantage of the reorganized engineer structure and the Corps' proficiency in light railway construction. The Corps would build on the river crossing operations that had been necessary to cross the river Luce in the opening hours of the Amiens attack. The entire Corps resources of engineers, and the field companies and pioneer battalion of the British $11^{\text {th }}$ Division, were placed under the control of the Chief Engineer for work on bridges, roads, light railways and water supply before and during the attack. ${ }^{297}$ In the case of the $1^{\text {st }}$ Canadian Division, parties of one officer and 50 other ranks of engineers were to be attached to both the $1^{\text {st }}$ and $3^{\text {rd }}$ Brigades in order to ensure that they crossed the canal by providing the infantry with ladders or bridges. ${ }^{298}$ Successful operations after the blue line objective ${ }^{299}$ were dependent upon the speed with which the canal was bridged, and all

296“"B.W. Instructions No. 1," Part 2, General Idea of Operations, 23 September 1918, LAC, RG 9, III D2, vol 4794, file 52 .

297“"B.W. Instructions No. 2.”, Part 25 (i), 25 September 1918, LAC, RG 9, III D2, vol 4794, file 52. Hereafter B.W. No. 2.

298“"B-W. $1^{\text {st }}$ Canadian Division," Engineers, n.d., LAC, RG 9, III D2, vol. 4804, file 154, "Operations Canal Du Nord B.W."

${ }^{299}$ A.W. Currie to First Army, 16 September 1918, LAC, RG 9, III D2, vol 4794, file 52; G.W.L. Nicholson, Canadian Expeditionary Force, p. 443. The operation was divided into three phases, red, green and blue. The red line ran from Sains-lez-Marquion then south-east along the Marquion Defence Line. The green line was the limit reached by the initial barrage, and the attack was to halt on this line while the field artillery was moved east of the Canal. The blue line objective was the limit which could be reached on the first day. 
units were ordered to give the engineers "every possible facility and assistance to enable them to complete the bridges quickly." Because crossing the canal was so important to the operation, transport carrying bridging material was to be given the highest priority on all roads west of the canal. However, material for the permanent heavy bridges was not to be brought on until after the capture of the Blue Line. ${ }^{300}$

Another important component of the combined logistics system during offensive operations was the value of tramways. The Corps operations at the Canal du Nord called for them to be "pushed forward over the Canal with all possible speed in order that artillery ammunition may be delivered East of the Canal..."301 These tramways would aid materially in supporting the advance, as they were to deliver ammunition to two separate dumps and connect their line with a royal engineer park during the first phase of their work program. This was to be done after they had repaired and connected their rails to the track in the enemy's former forward area. ${ }^{302}$ The tramway construction program was to be accelerated over the Canal du Nord in order to keep artillery in support of the infantry as they progressed.

Just as bridging priorities were set during the Amiens battle, the crossings fabricated over the Canal du Nord were allotted to specific divisions. The divisions would also be responsible for controlling the traffic flow over the bridges in their respective

${ }^{300}$ B.W., No. 2, Part 25, Construction of Bridges, Roads \& Light Railways, (ii).

${ }^{301}$ B.W., No. 2, Part 25, Construction of Bridges, Roads \& Light Railways, (iv).

${ }^{302}$ Major C.R. Crysdale, “Operations. Canal Du Nord (B.W.) Orders and Instructions re.”, 26 September 1918, LAC, RG 9, III C5, vol. 4446, folder 3, file 5. The $2^{\text {nd }}$ Tramway company was to maintain and operate this line which ran as follows: Ecoust-Hendecourt-Queant-Inchy. Work forward from Inchy was divided into three parts that included a crossing over the canal. 
areas and an officer and staff would be detailed at crossing points to facilitate this. Each division was assigned specific roads, and was to make arrangements for westbound traffic, especially artillery wagons that were returning to replenish their supply of ammunition. ${ }^{303}$ Field artillery brigades that had reached the end of their firing range after the green line objective, held the highest crossing priority followed by ' $A$ ' echelon $1^{\text {st }}$ line transport of infantry brigades that were to operate beyond the blue line objective. ${ }^{304}$ Logistics were essential during the advance, and as a result supply and transport were given precedence after the fighting arms crossed the canal.

Since the front of attack on the Canal du Nord line was so narrow, the infantry, machine gunners, supporting artillery and the engineer bridging units were all crowded into a small area as they deployed, in the rain, on the night of 26/27 September 1918. After they had reached their assembly areas, hot food and rum were issued to fortify the men for the battle. If enemy artillery concentrated its fire on this assembly area, it would have been disastrous. To ensure this would not happen, the Counter Battery Staff Officer, McNaughton, was ready to destroy hostile batteries if needed before the designated zero hour. Secrecy was again deemed necessary and artillery ammunition was brought up by pack transport, dumps were camouflaged, and guns were moved up at the last minute. ${ }^{305}$

\footnotetext{
${ }^{303}$ B.W., No. 2, Part 26 (iv, v, vi), Allotment of Bridges Over Canal; B.W., No. 2, Part 27 (i, ii, iii, iv), Allotment of Roads.

${ }^{304}$ B.W., No. 2, Part 26 (vii) (a, b, c,d,e), Priority.; After these units, field artillery to be employed beyond the blue line had the next highest priority. Followed by $A$ echelon $1^{\text {st }}$ Line Transport of other infantry brigades and finally, under consideration prior to the attack that B Echelon $1^{\text {st }}$ Line Transport of leading infantry brigades to remain on the west side of the canal, in divisional reserve, until z plus 1 day.

${ }^{305}$ Archibald Macdonell, “"'The Old Red Patch." The $1^{\text {st }}$ Canadian Division at the Breaking of the Canal du Nord Line," Canadian Defence Quarterly vol. IX, no. 1 (October 1931), p. 15-16.
} 
At zero hour, on 27 September, the engineers attached to the $1^{\text {st }}$ Canadian

Division moved forward to carry out their duty of bridging the canal after the enemy was cleared from its western banks. The $3^{\text {rd }}$ Battalion Canadian Engineers were assigned to build crossings over the obstacle including several footbridges that would serve the infantry. ${ }^{306}$ The $4^{\text {th }}$ Battalion reported that the barrage supporting them was excellent, and that its assault company ("D" company), which included a tumpline platoon for carrying supplies and ammunition, "reached [its] objective in 12 minute[s]" despite having to go over the canal with help from attached engineers. ${ }^{307}$ Similarly, the $14^{\text {th }}$ Battalion reported that "troops who had been impatiently waiting went forward with great dash." ${ }^{308}$ While it is not overtly stated in all cases, these accounts indicate that the canal was bridged successfully in the opening minutes of the assault by engineers attached to infantry units.

The engineers had to fill a crater blown in a road that was "cut to ground level through the canal banks" in order to allow field artillery through. Meanwhile, a pontoon bridging operation that was initially held up by shelling and machine-gun fire, which resulted in the death of an officer, was completed by twenty to nine that morning. ${ }^{309}$ Other crossings during the morning's assault were made over the canal, thanks to excellent staff planning and engineering work by the Canadian Corps. Without the completion of

\footnotetext{
${ }^{306}$ War Diary, $1{ }^{\text {st }}$ Canadian Division, September to October 1918, "Report on Canal du Nord - Bourlon Wood and Cambrai Operations", ' $E$ ' Construction of Canal Crossings By the $1^{\text {st }}$ Brigade, Canadian Engineers, p. 24, LAC, RG 9, III D3, volume 4837, microfilm, reel T-1921, file 81. Hereafter Construction of Canal Crossings.

307“B-W Operations," "Sept. $27^{\text {th }}$ To Red Line $4^{\text {th }}$ Bn.", n.d, LAC, RG 9, III D, vol. 4804, file 154, "Operations Canal Du Nord B.W.".

308“"B-W Operations", “27th Sept To Red Line. 14 $4^{\text {th }}$ Battalion”, n.d., LAC, RG 9, III D, vol. 4804, file 154, "Operations Canal Du Nord B.W.".

${ }^{309}$ Construction of Canal Crossings, p. 24.
} 
infrastructure to allow artillery to get forward, the assault would not have been possible.

The logistical services in support of the infantry needed to cross over the canal.

On 27 September, at approximately 9 am the $1^{\text {st }}$ Division's trench munition dump was successfully moved across the canal south of Marquoin. This dump was again moved further east on 28 September. Lieutenant Clarkson, who was the commanding officer of the s.a.a. section of the DAC, also had responsibility over the division's trench munitions dump. This officer, along with the personnel that handled trench munitions and s.a.a., came under fire during the operation and lost 60 animals due to enemy shelling. German artillery managed to destroy large parts of the main trench munition dump, and if it had not been for the efforts of Lieut. McGovern and his men, who were charged with supplying s.a.a. and grenades to the infantry, more of the munitions would have gone up in flames. Yet these types of setbacks were not enough to halt the supply of trench munitions to the infantry, and the losses were factored in during the preparations. Through the efforts of the DAC and its personnel, the $1^{\text {st }}$ Division was able to keep up with the supply of these commodities, but as is customary when a military formation advances, the strain was heavy on the DAC's drivers and horses. ${ }^{310}$

While the Corps was working hard to keep its fighting arms supplied in the Canal du Nord battle area, the BEF as a whole was feeling the burden of increased ammunition expenditures and the logistical difficulties of advancing further away from its base ports.

\footnotetext{
${ }^{310}{ }^{\text {c }} 1$ st Canadian Division. Report on Administrative Arrangements for Bourlon Wood \& Cambrai Operations. September 27 $7^{\text {th }}$ to October $5^{\text {th }} 1918$," Trench Munitions During the Battle, Sept. 1918, LAC, RG 9, III D2, vol 4793, file 45, " $1^{\text {st }}$ Canadian Division Report On Canal Du Nord Bourlon Wood and Cambrai Operations Sept. $27^{\text {th }}-$ Oct $2^{\text {nd }}$ Inclusive 1918."
} 
Both formations were able to adapt, but not without consequences for the Canadians. The opening days of the Canal du Nord battle saw the firing of 62,813 tons of ammunition, and the BEF had to replenish this output with a shortage of rolling stock on their broadgauge system. ${ }^{311}$ As at Amiens, the problem occurred on the BEF level. Ammunition trains and the divisional pack trains were straining under the increased demand, arrived late, which in turn had repercussions in the Canadian Corps' battle area. On 1 October, the Canadian Corps had an ammunition shortage. AA \& QMG Sutherland Brown of the $1^{\text {st }}$ Division stated that because of the irregular arrival times of broad-gauge trains, several expected lorry loads of ammunition failed to arrive. The resumption of the attack, scheduled for $5 \mathrm{pm}$ of that day, had to be cancelled because there were only 150 rounds at each gun. Later that evening, the shortfall was made up as one light railway load arrived along with 40 to 50 lorry loads. ${ }^{312}$

Despite the impact that increased ammunition expenditure had on the BEF's lines of communication and the enemy's tenacity while fighting defensively behind a formidable logistical and tactical barrier, the Canal du Nord and the fight for Cambrai ended for the Canadians on 11 October. From 26 August to 11 October, the Corps had advanced 23 miles against the strongest defences on the Western Front. ${ }^{313}$ They had managed to win victories at the sharp end of battle and successfully cut the Germans'

\footnotetext{
${ }^{311}$ Ian M. Brown, British Logistics on the Western Front, p. 197.

312، 1 st Canadian Division. Report on Administrative Arrangements for Bourlon Wood \& Cambrai Operations. September $27^{\text {th }}$ to October $5^{\text {th }} 1918$," Gun and Howitzer Ammunition", Sept. 1918, p. 7, LAC, RG 9, III D2, vol 4793, File 45, " 1 st Canadian Division Report On Canal Du Nord Bourlon Wood and Cambrai Operations Sept. 27 ${ }^{\text {th }}$-Oct $2^{\text {nd }}$ Inclusive 1918."

${ }^{313}$ G.W.L. Nicholson, Canadian Expeditionary Force, p. 459.
} 
road and rail communications that ran into Cambrai. ${ }^{314}$ Tramways and light railways were constructed, bridging operations were performed under fire, ammunition dumps moved, and railheads cleared. The operational system that had emerged in the Canadian Corps relied on the killing power of artillery, heavy machine guns and a wide range of infantry weapons. This attack style was, in turn, based on the combined logistics system, which strove to render the fighting arms as effective as possible and at the same time counteract the interdiction efforts of the enemy through a flexible combined logistics approach. Earlier evolutionary structural changes from 1915 to 1918 had provided a robust logistical system that could overcome the frictions inherent in dealing with a period of continual operations and was able to supply the fighting arms with the ammunition, equipment and rations necessary to enable it to fight and to consolidate its newly won territory.

After the capture of Cambrai, the Canadian Corps crossed the Canal de la Sensée on 12 October in pursuit of a rapidly retiring German Army. ${ }^{315}$ The chase to the outskirts of Valenciennes has often been described as a period of open warfare, yet this is not entirely accurate. Not only did the Canadians have to contend with lengthening supply lines, which strained logistics at the Corps level, but they also had to repair a logistical infrastructure devastated by a number of large battles and a withdrawing enemy that was leaving destruction in his wake. The Germans, in their bid to slow down their pursuers,

\footnotetext{
${ }^{314}$ E.W.B. Morrison, "Operations of Canadian Corps Artillery In the Field For Year 1918", nd. p. 7, LAC, RG 9, III C1, vol. 3893, folders 56, file 4.

${ }^{315}$ A.G.L. McNaughton, "The Capture of Valenciennes "A Study in Co-ordination,"” Canadian Defence Quarterly vol. X, no. 3 (April 1933), p. 279.
} 
engaged in a scorched earth policy that destroyed railways (light and standard-gauge), roads, and bridges. The enemy made areas impassable by manipulating water levels by means of canals, which were under German control. Although the Canadians had to devote much of their engineering resources to repair communications, ${ }^{316}$ they still managed to surpass these obstacles and maintained constant touch with the enemy. ${ }^{317}$ One soldier remarked that "whole fields were inundated in this area, but of course it did not interfere with our heavy transport and artillery moving up, for there are plenty of parallel roads." 318 The Corps' engineers were instructed to take measures to repair damaged sluices and control gates in order to gain control over the flow of water to rectify the situation..$^{319}$ The Canadians were forced to negotiate and repair this shattered landscape while moving further away from its railheads, still managing to keep up with the retreating Germans. It is often forgotten that railheads did not remain static during this period. The Corps was using its own engineer and labour resources to further the end of steel on the broad-gauge system during the advance. ${ }^{320}$ Finally, the Canadians had to deal with a large number of civilians in the devastated area who were badly in need of food.

${ }^{316}$ Currie, Corps Operations, p. 173.

${ }^{317}$ “ $4^{\text {th }}$ Canadian Division Report Valenciennes Operations Oct $27^{\text {th }}$ to Nov. $6^{\text {th" }}, 6$ January 1919, p. 4 , LAC, RG 9, III D2 vol 4797, file 84.

${ }^{318}$ John Menzies, "Following Fritz, October 1918," in J.L .Granatstein and Norman Hillmer (eds.), Battlelines: Eyewitness Accounts From Canada's Military History, p. 203.

319"'Engineer Instructions No. 32. Control of Water in Canals,"12 October 1918, LAC, RG 9, III D, vol. 4794, file 52.

320"Report On Work Covered, October, 1918", Broad Gauge Railways, 8 November 1918, LAC, RG 9, III C5, vol. 4449, folder 1, file 1; Kerry and McDill, History of the Corps of Royal Canadian Engineers, p. 203. On 18 October, ' $B$ ' company $6^{\text {th }}$ Battalion Canadian Engineers were working on broad-gauge railways. 
By 18 October, the Canadians were providing 70,000 civilians with food. ${ }^{321}$

Despite this wide array of pressing concerns that added to the friction of war, the Canadians still managed to prepare for its last set-piece battle at Valenciennes. The 30 mile haul from the Corps ammunition railhead was problematic, but was overcome by the Corps' willingness to leave its siege guns parked in the rear areas, which freed up a large number of lorries to haul ammunition. ${ }^{322}$ Because the $4^{\text {th }}$ Canadian Division's logistic net was strained due to the enemy's destruction of infrastructure in the area, and the wear and tear on the Corps' lorries, the MT had to overcome tremendous difficulties in order to bring up an adequate supply of artillery ammunition giving the infantry the support it needed to take Mount Houy ridge. ${ }^{323}$ The logistical ability of the Corps was shown, when before midnight on 31 October/ 1 November, dumps of $400 \mathrm{rds}$ per gun were established. This task, which was completed in two days, ${ }^{324}$

on schedule over few and congested roads, only usable at night and under repeated bursts of heavy fire which occasioned many casualties, reflects the highest credit on the discipline and courage of our Field Artillery, and on the care and ability of the Staffs who planned this deployment and who supervised the road control. ${ }^{325}$

The result of these logistical efforts amounted to the densest artillery barrage ever fired in support of a single infantry brigade during the war. The Canadian Corps expended

\footnotetext{
${ }^{321}$ Currie, Corps Operations, p. 174; "Rationing and Disposition etc. of Civilians in Reoccupied Territory”, 12 August 1918, LAC, RG 9, III C1, vol. 3887, folder 39, file 11.

${ }^{322}$ A.G.L. McNaughton, "The Capture of Valenciennes "A Study in Co-ordination,"” p. 282.

$323_{\text {“ }} 4^{\text {th }}$ Canadian Division Report Valenciennes Operations Oct $27^{\text {th }}$ to Nov. $6^{\text {th" }}, 6$ January 1919, p. 5. LAC, RG 9, III D2 vol 4797, file 84.

${ }^{324}$ Shane Schreiber, Shock Army of the British Empire, p. 123.

${ }^{325}$ A.G.L. McNaughton, "The Capture of Valenciennes "A Study in Co-ordination,"” p. 285.
} 
87,774 artillery rounds of all types during the set piece battle. ${ }^{326}$ Over two thousand tons were fired, which was approximately the equivalent of all artillery ammunition fired in the South African War. ${ }^{327}$

The Corps, through its logistical support system, was able to use materiel rather than men to bring their last set-piece battle of the war to a close. Over the course of the war, the Canadian Corps had become adept at supplying itself with the ammunition and supplies necessary to mount a firepower and consolidation based attack system that the Germans could not counteract.

${ }^{326}$ W.H. Anderson, "The Operations Round Valenciennes by the First Army, October-November, 1918," Canadian Defence Quarterly, vol. II, no. 3 (April 1925), p. 297.

${ }^{327}$ A.G.L. McNaughton, "The Capture of Valenciennes "A Study in Co-ordination”", p. 293; Schreiber, p. 123. 


\section{Conclusion}

Even though historians have quite rightly focussed on the comparatively dramatic increase in fire power used by armies during the First World War, they have rarely discussed how ammunition expenditures and massive armies were supported logistically in the field. Part of the problem facing historians is the difficulty in measuring logistical success or failure. In 1928, H.W. Johnston aptly stated that any future improvement, which reduced mechanical failures and increased capabilities would be more than offset by the damage that better tanks and improved mobile weapons could inflict on them. ${ }^{328}$ Similarly, Martin van Creveld has insisted that, throughout the twentieth century, increases in the speed, range and carrying capacity of logistical transport were accompanied by dramatic increases in the forces acting against them. The heightened combat power of the fighting arms, the challenge of maintaining long lines of communication, climbing maintenance concerns and the increase in the amount of supplies that were required by units, have the potential to negate the increased potential of any new logistics. ${ }^{329}$ Put simply, with increased logistical capability comes a proportionate increase in the friction of war. The improved ability to logistically deliver the means to wage war would invariably lead to a proportionate increase in friction. A mobile force during the Israeli-Egyptian war of 1967, for instance, operating under ideal conditions, and dominating the air, could not advance farther than 40 miles per day. ${ }^{330}$

\footnotetext{
${ }^{328}$ H.W. Johnston, "Fuel: Another Sinew of War," Canadian Defence Quarterly vol. VI, no. 1 (October 1928), p. 69.

${ }^{329}$ Martin van Creveld, Supplying War, p. 235.

${ }^{330}$ Ibid.
} 
Even a perfect logistical system would be subject to the friction of war. The question of logistical success or failure, therefore, should be based on what a particular military formation achieved within the context of the time.

During its time on the Western Front, the Canadian Corps staff officers attempted to maximize the potential of its logistical services through the use of the combined logistics system. In spite of friction, in the form of terrain, enemy attempts at interdiction, maintenance problems, the extension of lines of communication, and any number of factors that acted against them, the Corps' supply and transport services were able, through the flexible nature of their system, to offset the effects. If one mode of transport was interdicted, over-extended or broken down, another mode could replace it. The enormity of logistical tasks was not lost on the Canadians, and their willingness to devote much of their manpower resources to engineering and labour tasks is a testament to their appreciation for infrastructure development. Not only was a flexible system needed, but vast numbers of men, both skilled and unskilled, were required to carry out road work, lay track, construct billets, and build bridges. These logistical endeavours had a direct impact on the efficiency and successes of the fighting arms. Sound logistics was a major element responsible for the Canadian Corps' striking power. The weight of artillery and machine gun fire that the Canadian Corps could bring to bear was possible not only because of logistical improvements that had occurred at the BEF level, but because improvements and innovations were made to its Corps level logistical system throughout the war. Without shells, s.a.a., rations, fodder, and equipment, the Corps would have lost its combat power as the strength and morale of the men would have eroded and weapons 
rendered useless without ammunition.

The system that evolved in the Canadian Corps, which was based on the British model, was modified and improved through the lessons and experience garnered during the war and the ability of Canadian officers to implement their ideas. At Ypres in 1915, the Canadians had realized that they needed more personnel to undertake the task of maintaining the logistical infrastructure of the Corps, and that using manpower from infantry and other units was merely a temporary solution. Commanders concluded that more labour would be required to maintain their defensive positions and logistical communications while at the same time conserving the effectiveness of their fighting arms, especially the infantry. Large scale battles presented unforeseen difficulties as infantry and artillery ammunition had to be continually supplied in order to blunt enemy attacks.

At the Somme, during offensive operations, the BEF soon learned that communications had to be adequately prepared in the battle area to continually supply shells, s.a.a. and other stores during the fighting. There was a tactical breakdown on the Somme as infantry advanced in line towards uncut belts of barbed wire and fortified machine-gun positions, but there were logistical oversights as well. Logistics in the battle area were rendered ever more difficult as the battle proceeded, since roads became worn and impassable. The Canadians on the Somme realized the importance of consolidating any gains that they had made. In order to fend off counter-attacks in the short term, supplies were brought forward using tumplines and pack animals, and to insure that gains could be held more permanently, tramways had to be rushed forward to supply the 
infantry that held them. Furthermore, the Canadians concluded that continuous running made mechanical transport more efficient and that the conveying of commodities to the forward area had to be streamlined to save valuable manpower. These were important lessons learned. They were incorporated into the overall logistical scheme for future engagements such as Vimy, Passchendaele, Amiens, Canal du Nord, and Valenciennes.

Prior to the Vimy Ridge assault, the Canadians, while working closely with their British allies, had put into place the combined logistic system that featured a high degree of flexibility, whereby interdicted modes of transport were backed up by another system during the build up for the operation. Although friction acted on this system, its elastic nature made it able to offset difficulties. Horse transport, lorries, pack animals, and narrow-gauge railways were all used by the Corps to support the infantry, artillery, and engineers. The build up for the battle was a monumental affair, but logistical arrangements extended after zero hour too. Roads and tramlines were pushed forward after the advance to insure that the position could be held.

Just as the Canadians had realized that sound logistics were essential for undertaking successful offensive operations, they also took into account how important these same considerations were for the enemy. W.A. Griesbach, who commanded a brigade in the CEF, certainly gained this lesson from his First World War experience, that just as the Canadians realized that logistics were important for themselves, they were equally important for the enemy. ${ }^{331}$ German logistics were successfully disrupted at Vimy,

\footnotetext{
${ }^{331}$ Major-General W.A. Griesbach, “Military Study”, Canadian Defence Quarterly, vol. vii no. 1(October 1929), p. 22.
} 
as artillery was turned on the enemy's rear areas to delay ration delivery and to harass other resupply efforts. It was determined later that this effort contributed to weakness in the enemy defence.

After the battle for Vimy Ridge, the Canadians were once again called upon to fight in the Ypres salient. In previous accounts of the battle, the logistical preparations have been given more attention than the other engagements of the Canadian Corps because the poor conditions were so pronounced. Due to the terrain, it has been impossible for historians to deal with the battle without some consideration of logistics. However, most discussions of the battle have pointed to the supposed futility of the endeavour rather than examining the ingenuity, effort and determination displayed by the Canadians to relentlessly build-up infrastructure prior to and during the battle. Passchendaele revealed the importance of sound logistical planning for successful offensive operations, and Currie refused to commit his Corps until the necessary preparations were made. The plank roads of Vimy were again constructed, a tramway pushed forward and duck board tracks laid across the muddy wastes.

The Canadians had learned from past experience that success in battle was dependent upon logistical preparations, which were appreciated and insisted upon by the Corps commander, Currie. His staff knew that roads and tramways were needed to supply shells to the artillery, and that re-supply arrangements were required during the battle as infantry consolidated newly won positions. Currie outlined several key factors that contributed to the Corps reaching its objectives, and two of them were related to logistics. He felt that the extra preparation time he had been given insured that improvements to the 
combined logistics net could be made. These improvements allowed the artillery to be supplied with the ammunition necessary to support his troops when they attacked. Currie further stated that the roads and tramlines built, maintained, and operated by the Canadian Corps were crucial in supplying the artillery.

It was through logistical excellence that the Canadian Corps was able to mount the successful attack at Amiens under conditions of extreme secrecy that kept Canadian logisticians in the dark shortly before the Corps move from Arras to the Amiens. In spite of the tremendous pressure that was placed on them, Q staff managed to move the Corps into an attack position clandestinely. They overcame the friction associated with operating in conditions shrouded by secrecy, and were able to supply the material and transport necessary for one of the war's great victories. Behind the advance, engineers and labourers worked hard to improve the logistical infrastructure in their areas following Amiens and after the Battle of Arras. They not only aided in the construction of narrowgauge railways, but Corps labourers worked to construct broad-gauge railways as well. Furthermore, the battle of the Canal du Nord could not have proceeded without meticulous planning and execution on behalf of the Corps' logistical services and the engineers in particular. Bridges were constructed at the battle's outset, which allowed infantry and artillery to move across the canal along with transport that would ensure the continual supply of ammunition.

The pursuit from Cambrai to Valenciennes highlighted the ability of the mechanized component of the Corps to overcome maintenance problems and increasing distance from railheads through flexibility and innovation. The forces of friction acting 
against the Corps during the pursuit to Valenciennes were enormous: the lengthening of the lines of communication, a need to care for a displaced civilian population, and the pressure to repair an infrastructure destroyed in battle by an enemy determined to slow the Corps' forward progress. Despite all of these elements working against it, the Corps still managed to maintain touch with the enemy. Using its logistical abilities, the Corps was able to mount some of the most effective offensives on the Western Front and, in the final days of the war, was able to keep pace with a rapidly retiring enemy bent on slowing the Corps' progress in any way possible. Through combined operations, featuring a number of fighting arms and a sound logistical system, the Canadian Corps had become one of the most potent offensive forces on the Western Front. An army may march on its stomach, but its movements require roads and railways, all of which have to be planned by officers working under the constraints of time and space. Logistics provide the muscle and sinew of the tactical and operational arm, they are the fuel lines and petrol that run the engine of war. 


\section{Bibliography}

\section{Unpublished Primary Sources}

1. Library and Archives Canada

a) Record Groups

RG 9, III C1,

Vol. 3877 Burials, Recreation Huts, Equipment

Vol. 3879 Labour, Billets

Vol. 3885 Administrative Reports Vimy and Passchendaele

Vol. 3887 Remounts, Civilians, Railways

Vol. 3889 Secrecy 1916, Equipment, Transport

Vol. 3890 Transport, Trophies, Engineers

Vol. 3891 Water Supply, Equipment

Vol. 3893 History of the Canadian Corps 1918, Rations

Vol. 3894 Horse Transport, Vehicles, Equipment

RG 9, III C5,

Vol. $4445 \quad 1^{\text {st }}$ Tramways Company

Vol. $4446 \quad 2^{\text {nd }}$ Tramways Company

Vol. $4447 \quad 2^{\text {nd }}$ Tramways Company

Vol. $4448 \quad 3^{\text {rd }}$ Division Pontoon Bridging and Transport

Vol. $4449 \quad 4^{\text {th }}$ Division Pontoon Bridging and Transport

RG 9, III C6

Vol. 4449 Headquarters Canadian Labour Group

RG 9, III C9

Vol. $4530 \quad 2^{\text {nd }}$ Divisional Train and $1^{\text {st }}$ Divisional Train

RG 9 III D2

Vol. 4789 Amiens, War Diaries, Canadian Corps General Staff

Vol. 4793

Amiens, Canal Du Nord, Bourlon Wood

Vol. 4794

Operation Orders, Narratives

Vol. 4795

Amiens

Vol. 4797

Administrative Reports, Valenciennes

Vol. 4804

Canal du Nord

Vol. $4810 \quad$ Miscellaneous

RG 9, III D3

Vol. 507

27th Division

Vol. 4816 Canadian Corps, General Staff. 
Vol. $4837 \quad 1^{\text {st }}$ Canadian Division, Administrative Branches of the Staff and $1^{\text {st }}$ Canadian Division

Vol. $4840 \quad 1^{\text {st }}$ Canadian Division, Administrative Branches of the Staff

Vol. 4853 $3^{\text {rd }}$ Canadian Division, General Staff

Vol. 4924 15th Canadian Infantry Battalion

Vol. 4977 1st Canadian Divisional Ammunition Column, War Diaries, $2^{\text {nd }}$ Canadian Heavy Battery

Vol. 4990 $1^{\text {st }}$ Brigade, Canadian Engineers

Vol. 5022 $1^{\text {st }}$ Canadian Divisional Ammunition Sub-Park

Vol. 5058 Canadian Corps, Operations, Vimy

b) Manuscript Groups MG 30, E 54, MG 30, E 81, F.R. Phelan Papers E.W.B. Morrison Papers

\section{Official Histories and Published Primary Sources}

Currie, A.W., Canadian Corps Operations During the Year 1918 - Interim Report (Ottawa: Department of Militia and Defence, 1919).

Beadon, R.H., The Royal Army Service Corps. A History of Transport and Supply in the British Army (Cambridge: Cambridge University Press, 1931).

Duguid, A.F., Official History of the Canadian Forces in the Great War, 1914-1919, General Series. Vol.1: Chronicle, August 1914-September, 1915 (Ottawa: King's Printer, 1938). , Official History of the Canadian Forces in the Great War 1914-1919 vol. 1, Chronology, Appendices and Maps (Ottawa: King's Printer, 1938).

Edmonds, James E., Military Operations France and Belgium, 1916 (London: HMSO, 1932).

Henniker, A.M., Transportation on the Western Front, 1914-1918 (London: HMSO, 1937).

Kerry, A.J. and W.A. McDill, The History of the Corps of Royal Canadian Engineers, Vol 1 (Ottawa: Military Engineering Association of Canada, 1962).

Macphail, Andrew, Official History of the Canadian Forces in the Great War, 19141919: The Medical Services (Ottawa: F.A. Ackland, 1925). 
Nicholson, G.W.L., Canadian Expeditionary Force, 1914-1919: The Official History of the Canadian Army in the First World War (Ottawa: Queen's Printer, 1962).

Nicholson, G.W.L., The Gunners Of Canada. The History of the Royal Regiment of Canadian Artillery volume I, 1534-1919 (Toronto: McClelland and Stewart,1967).

Various, Report of the Ministry: Overseas Military Forces of Canada 1918 (London: HMSO, 1919).

\section{Published Personal Experiences}

"The Adjutant," The $116^{\text {th }}$ Battalion in France (Toronto: E.P.S. Allen, 1921).

Becker, John Harold, Silhouettes of the Great War (Ottawa: CEF Books, 2001).

Black, Ernest G., I Want One Volunteer (Toronto: Ryerson, 1965).

Bird, Will, Ghosts Have Warm Hands (Ottawa: CEF Books, 2002).

Burns, E.L.M., General Mud. Memoirs of Two World Wars (Toronto: Clarke Irwin, 1970).

Cane, Bruce, It Made You Think of Home. The Haunting Journal of Deward Barnes, Canadian Expeditionary Force: 1916-1919 (Toronto: Dundurn, 2004).

Fraser, Donald, The Journal of Private Fraser (Nepean: CEF Books, 1998).

Granatstein, J.L. and Norman Hillmer (eds.), Battlelines: Eyewitness Accounts From Canada's Military History (Toronto: Thomas Allen Publishers, 2004).

Johnston, James, Riding into War (Fredericton: Goose Lane Editions, 2004).

Wheeler, Victor W., The 50 $0^{\text {th }}$ Battalion in No Man's Land (Ottawa: CEF Books, 2000).

\section{Theses}

Brown, Ian M., "Lieutenant-General Sir Arthur Currie and the Canadian Corps 19171918: The Evolution of a Style of Command and Attack," MA Thesis, University of Calgary, 1991.

Campbell, David C. G., "The Divisional Experience in the C.E.F.: A Social and Operational History of the 2nd Canadian Division, 1915--1918," PhD Thesis, 
University Of Calgary, 2004.

Camsell, James F., "From Normandy to the Scheldt. Logistics and the First Canadian Army (June-September 1944)," MA Thesis, University of New Brunswick, 1995.

Jenkins, Dan, "Winning Trench Warfare: Battlefield Intelligence in the Canadian Corps, 1914-1918," Ph.D. Thesis, Carleton University, 1999.

Porter, Neal, "From Trench to Open Warfare: The State of Logistics in the Canadian Corps, August to November 1918," MA memoire, University of Ottawa, 1998.

Radley, Kenneth, "First Canadian Division, C.E.F., 1914-1918: Ducimus (We Lead)," $\mathrm{PhD}$ Thesis, Carleton University, 2000.

\section{Published Secondary Sources}

Ashworth, Tony, Trench Warfare 1914-1918. The Live and Let Live System (London: Macmillan, 1980).

Asprey, Robert, The German High Command At War: Hindenburg and Ludendorff Conduct World War I (New York: William Morrow, 1991).

Bellamy, Christopher, The Evolution of Modern Land Warfare (New York: 1990).

Berton, Pierre, Vimy (Canada: Anchor, 2001). , Marching As to War. Canada's Turbulent Years, 1899-1953 (Canada: Anchor, 2002).

Blaxland, Gregory, Amiens: 1918, (London: Frederick Muller,1968).

Brown, Atholl Sutherland, Buster, A Canadian Patriot and Imperialist. The Life and Times of Brigadier James Sutherland Brown (Waterloo: Trafford, 2004).

Brown, Ian M., British Logistics on the Western Front (Westport, Conn.: Praeger, 1998).

Busch, Briton C., Canada and the Great War. Western Front Association Papers (Kingston: McGill-Queen's, 2003).

Cook, Tim, No Place to Run: The Canadian Corps and Gas Warfare in the First World War (Vancouver: UBC Press, 1999). 
Creveld, Martin van, Supplying War: Logistics From Wallenstein to Patton (London: Cambridge University Press, 1977).

Daniel Dancocks, Legacy of Valour (Edmonton: Hurtig, 1986). , Spearhead to Victory (Edmonton: Hurtig, 1987). ,Welcome to Flanders Fields (Toronto: McClelland and Stewart, 1988). , Sir Arthur Currie: A Biography (Toronto: Methuen, 1985).

Davies, W.J.K., Light Railways of the First World War: A History of Tactical Rail Communications on the British Battlefronts, 1914-1918 (Newton Abbot: David and Charles, 1967).

Dennis, Peter and Jeffrey Grey (eds.), 1918: Defining Victory (Canberra: Army History Unit, 1998).

English, John A. and Bruce I. Gudmundsson, On Infantry. Revised Edition (Westport, Conn.: Praeger, 1994).

Ferguson, Niall, The Pity of War (New York: Basic Books,1999).

Granatstein, J.L., Canada's Army. Waging War and Keeping the Peace (Toronto: University of Toronto Press, 2002). , and Desmond Morton, Canada and the Two World Wars (Toronto: Key Porter, 2003).

Gudmundsson, Bruce I., On Artillery (London: Praeger,1993).

, Bruce I., Stormtroop Tactics. Innovation In The German Army, 1914-1918 (Westport, Conn.: Praeger, 1989).

Holmes, Richard, Tommy: The British Soldier On the Western Front 1914-1918 (London: Harper Collins, 2004).

Hyatt, A.M.J., General Sir Arthur Currie (Toronto: University of Toronto Press, 1987).

Kitchen, Martin, The German Offensives of 1918 (Charleston, SC: Tempus, 2001).

Love, David W., 'A Call to Arms' The Organization and Administration of Canada's Military in World War One (Calgary: Bunker to Bunker Books, 1999). 
MacKenzie, David ed., Canada and the First World War. Essays in Honour of Robert Craig Brown (Toronto: University of Toronto Press, 2005).

McWilliams, James L., and R. James Steel, The Suicide Battalion (Edmonton: Hurtig, 1978). , Amiens Dawn Of Victory (Toronto: Dundurn, 2001).

Rawling, Bill, Surviving Trench Warfare: Technology and the Canadian Corps, 19141918 (Toronto: University of Toronto, 1992) , Technicians of Battle (Toronto: Military Engineering Institute of Canada, 2001).

Schreiber, Shane B., Shock Army of the British Empire: The Canadian Corps in the Last 100 Days of the Great War (St. Catharines: Vanwell, 2004).

Swettenham, John, To Seize the Victory (Toronto: Ryerson, 1965). , McNaughton, Vol.1, 1887-1939 (Toronto: Ryerson, 1968).

Thompson, Julian, The Lifeblood of War (London: Brassey's, 1991).

Thorpe, George, Pure Logistics (Washington: National Defense University Press, 1917).

Travers, Tim, The Killing Ground (London: Allen and Unwin, 1987). , How the War Was Won: Command and Technology in the British Army on the Western Front (London: Pen and Sword, 1992).

Urquhart, H.M., Arthur Currie: The Biography of a Great Canadian (Toronto: J.M. Dent, 1950).

Warren, Arnold, Wait for the Waggon: The Story of the Royal Canadian Army Service Corps (Toronto: McClelland and Stewart Limited, 1961).

Weatherbe, K., From the Rideau to the Rhine and Back. The $6^{\text {th }}$ Field Company and Battalion Canadian Engineers in the Great War (Toronto: Hunter-Rose, 1928).

Williams, Jeffrey, Byng of Vimy: General And Governor General (Toronto: Secker and Warburg, 1992).

Wise, S.F., Official History of the Royal Canadian Air Force, vol.1: Canadian Airmen 
and the First World War (Toronto: University of Toronto Press, 1980).

Wood, Herbert Fairlie, Vimy! (London: MacDonald, 1967).

\section{Articles}

Anderson, W.H., "The Operations Round Valenciennes by the First Army, OctoberNovember, 1918," Canadian Defence Quarterly Volume II (3), April, 1925.

Boire, Michael, "The Underground War: Military Mining Operations in support of the attack on Vimy Ridge, 9 April 1917," Canadian Military History Volume 1 (1\&2), Autumn, 1992.

Brown, Ian M., "Not Glamorous, But Effective: The Canadian Corps and the Set-Piece Attack, 1917-1918," The Journal of Military History Volume 58(3), July, 1994.

,"Feeding Victory: The Logistic Imperative Behind the Hundred Days," in Peter Dennis and Jeffrey Grey, (eds.), 1918: Defining Victory (Canberra: 1999).

Burns, E.L.M, "Protection of the Rearward Services and Headquarters in Modern War," Canadian Defence Quarterly Volume X (3), April, 1933.

Chappelle, Dean, "The Canadian Attack at Amiens, 8-11 August 1918," Canadian Military History Volume 2 (2), April, 1993.

Cook, Tim, “'Literary Memorials': The Great War Regimental Histories, 1919-1939," Journal of the Canadian Historical Association, New Series, Volume 13, 2003.

"“'More a medicine than a beverage"'Demon Rum' and the Canadian Trench Soldier of the First World War," Canadian Military History, Volume 9 (1), Winter, 2000.

Copp, Terry, "The Military Effort, 1914-1918,"in David MacKenzie ed., Canada and the First World War (Toronto: 2005).

Eddy, K.T., "The Canadian Forces and the Operational Level of War," Canadian Defence Quarterly Volume 21(5), April, 1992.

Griesbach, W.A., "Military Study," Canadian Defence Quarterly Volume VII (1), October, 1929.

Grieves, Keith, "Improvising the British War Effort: Eric Geddes and Lloyd George, 1915-18," War \& Society Volume 7 (2), September, 1989. 
Gustavson, Wes, "'Fairly Well Known and Need Not be Discussed' Colonel A.F. Duguid and the Canadian Official History of the First World War," Canadian Military History Volume 10 (2), Spring, 2001.

Hertzberg, H.F.H., "The Re-Organization of the Engineering Troops of a Canadian Division - Great War 1914-18," Canadian Defence Quarterly Volume 1 (4), July, 1924.

Johnston, H.W., "Fuel: Another Sinew of War," Canadian Defence Quarterly Volume VI (1), October, 1928.

Long, C.E., "Ammunition Supply During the Great War With Special Reference to the $1^{\text {st }}$ Canadian Division," Canadian Defence Quarterly Volume. V (2), January, 1928.

Macdonell, Archibald, “"'The Old Red Patch," The $1^{\text {st }}$ Canadian Division at the Breaking of the Canal du Nord Line," Canadian Defence Quarterly Volume IX (1), October, 1931.

Matthews, H.H., "An Account of the Second Battle of Ypres, April, 1915, being the experience of a Company Commander prior to and during the fighting," Canadian Defence Quarterly Volume 1 (3), April, 1924.

McNaughton, A.G.L.,"The Capture of Valenciennes 'A Study in Co-ordination,"” Canadian Defence Quarterly, Vol. X (3), April, 1933.

Miller, Roger G., "The Logistics of the British Expeditionary Force, 4 August to 5 September 1914," Military Affairs, Volume 43 (3), October, 1979.

Phelan, F.R., "Army Supplies in the Forward Area and the Tumpline System," Canadian Defence Quarterly, Volume VI (1), October, 1928.

, "The Army and Its Stomach: The Thermos Pack," Canadian Defence Quarterly Volume VII (3), April, 1930.

Travers, Tim, "July 1, 1916: The Reason Why," in Robert Cowley ed., The Great War. Perspectives on the First World War (New York: 2003).

Wise, S.F., "The Black Day of the German Army: Australians and Canadian at Amiens, August 1918," in Peter Dennis and Jeffrey Grey, (eds.), 1918: Defining Victory (Canberra: 1999).

, “Amiens, August 1918: A Glimpse of the Future?"in Briton C. Busch, ed., Canada and the Great War. Western Front Association Papers, (Kingston: 2003). 


\section{Appendix I: General Scheme of Supply}

(From R.H. Beadon, The Royal Army Service Corps (Cambridge: 1931), p. 154)

\section{GENERAL SCHEME OF SUPPLY from the Base to the Trenches}

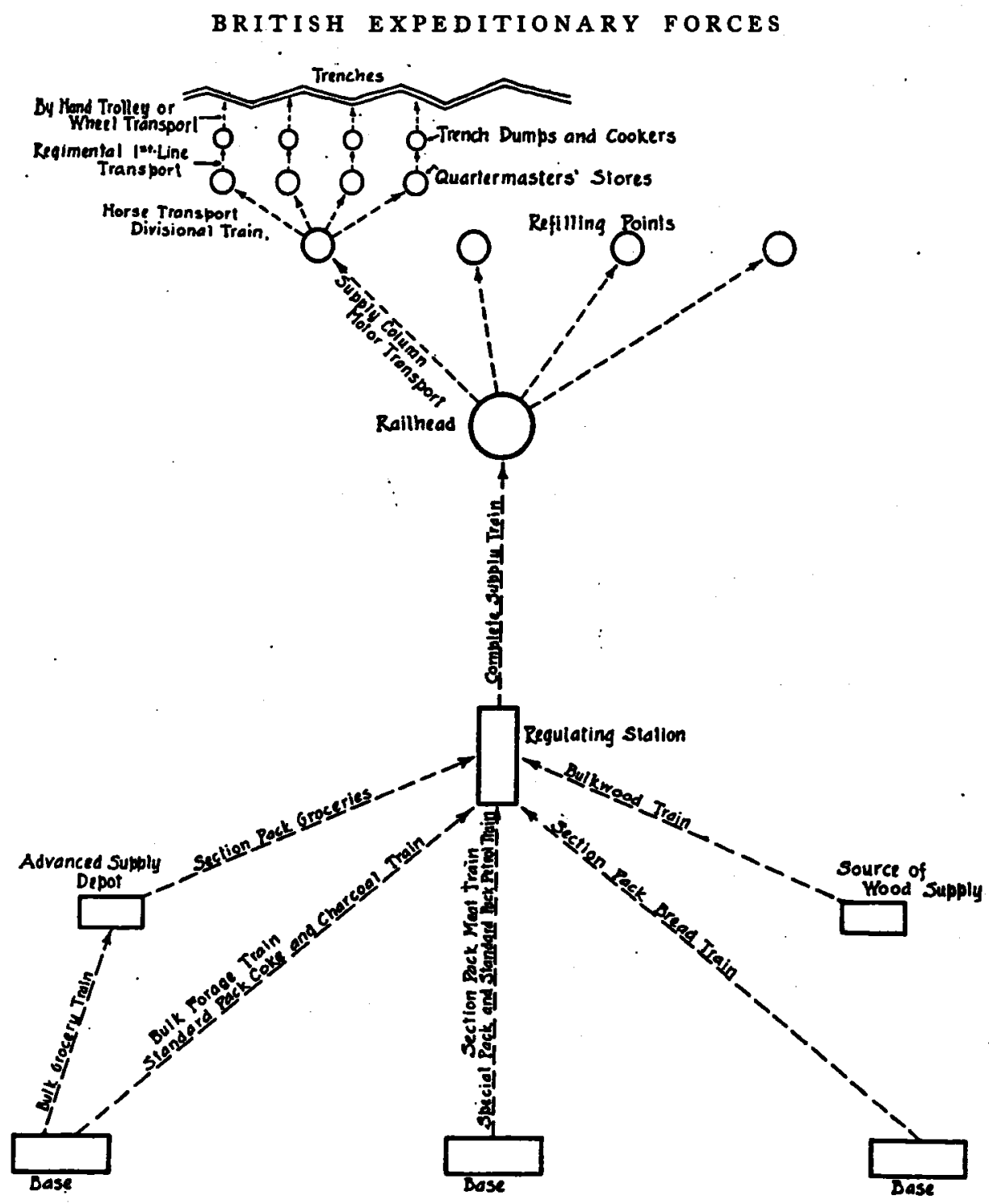


Appendix II: General Scheme of Supply, 1918

(From David W. Love, A Call to Arms (Calgary: 1999), p. 216)

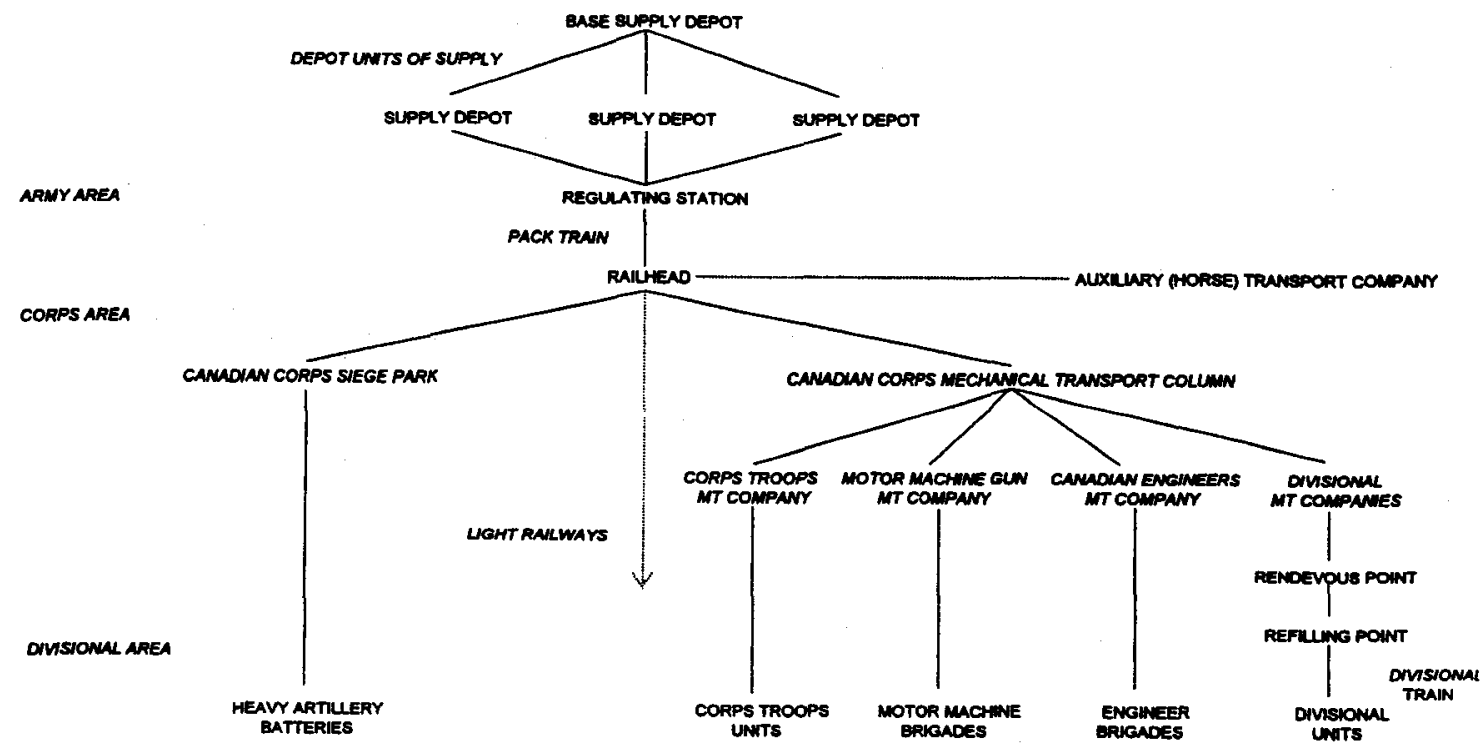


Appendix III: Light Railway, Tramway, and Lorry System, Vimy Ridge, 1917 (From Brig-Gen. R.H. Massie, "Notes On The Supply Of Heavy Ammunition During the Vimy Ridge Operations", 19 May 1917, LAC, RG 9, III C1, vol. 3885, folder 32, file 4)

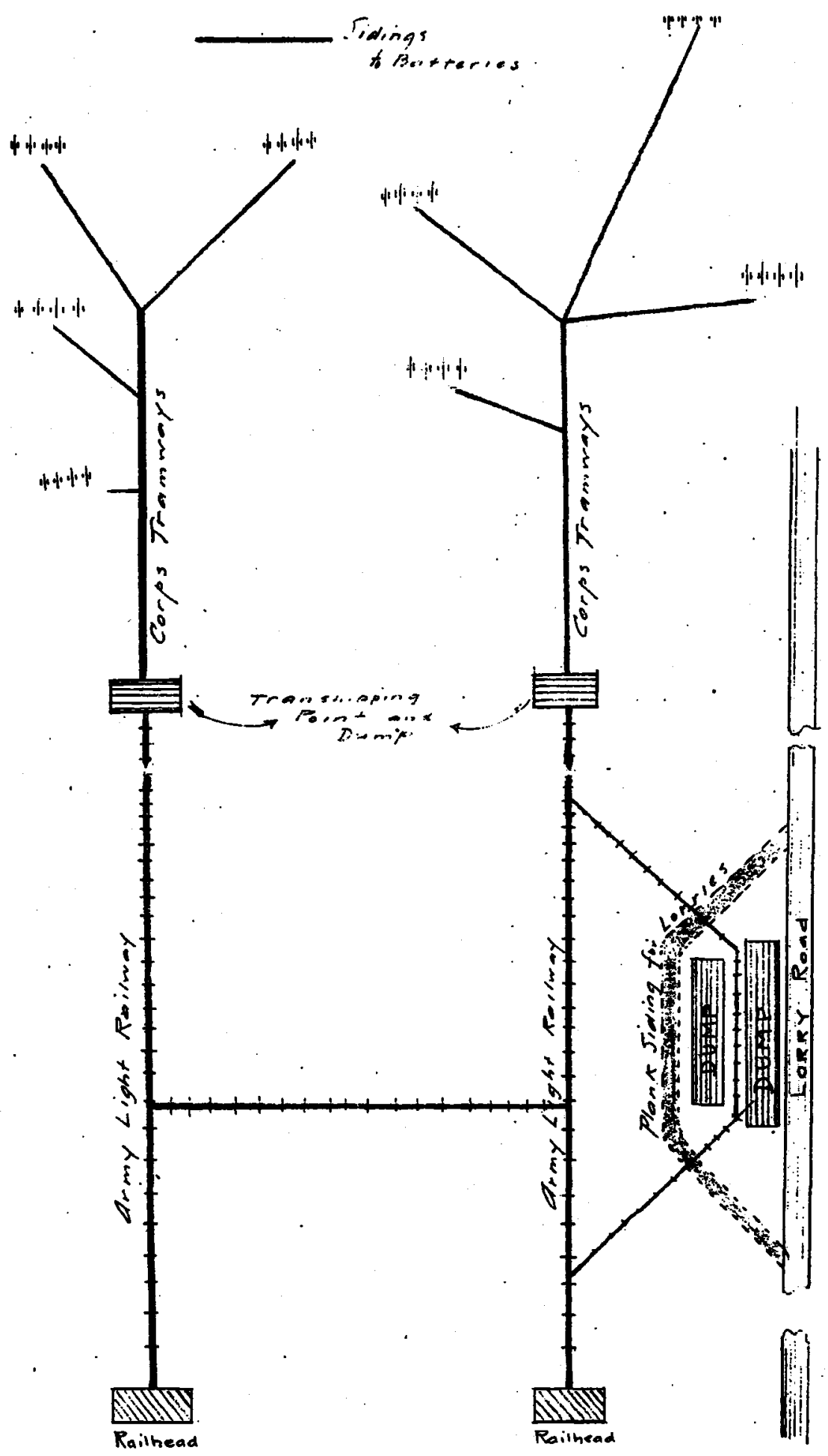

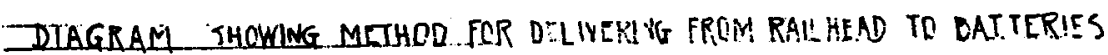

